RAFAEL DE AQUINO CUNHA

APLICAÇÃO DE TÉCNICAS DE INTELIGÊNCIA ARTIFICIAL PARA O GERENCIAMENTO DINÂMICO DE DISPOSITIVOS DE UM PABX DISTRIBUÍDO, DESENVOLVIDO COM A TECNOLOGIA LONWORKS ${ }^{\circledR}$ 
RAFAEL DE AQUINO CUNHA

\section{APLICAÇÃO DE TÉCNICAS DE INTELIGÊNCIA ARTIFICIAL PARA O GERENCIAMENTO DINÂMICO DE DISPOSITIVOS DE UM PABX DISTRIBUÍDO, DESENVOLVIDO COM A TECNOLOGIA LONWORKS ${ }^{\circledR}$}

Dissertação apresentada à Escola

Politécnica da Universidade de São Paulo para obtenção do título de Mestre em Engenharia

Área de Concentração:

Sistemas Digitais

Orientador: Prof. Livre-Docente Carlos

Eduardo Cugnasca

SÃO PAULO

2008 


\section{DEDICATÓRIA}

Dedico este trabalho à minha mãe, Elisabeth de Aquino, como forma de reconhecer seu esforço em me oferecer uma grande educação moral e me ensinar, não só a sonhar, mas que todos os sonhos podem ser concretizados através da força de vontade, atitude positiva e, principalmente, um bom caráter. Agradeço por me ensinar, através de seu exemplo vivo, que podemos ser e ter o que quisermos, sem que para isso seja necessário menosprezar outras pessoas ou esquecer que podemos amar. 


\section{AGRADECIMENTOS}

Ao meu orientador, prof. Livre-Docente Carlos Eduardo Cugnasca, por toda a paciência e orientação durante o desenvolvimento deste trabalho.

Ao meu grande amigo, doutorando Miguel dos Santos Alves Filho, por sua ajuda fundamental ao bom desenvolvimento deste trabalho e, por conseguinte, meu desenvolvimento acadêmico.

À minha esposa, Náthaly Piccoli Adamo, por toda ajuda, compreensão e companhia, durante os períodos de maior carga de trabalho.

Aos amigos Ricardo Lui Geh, Paulo Roberto Cardinali e Tercio Ferdinando Gaudencio Filho, por ajudar e apoiar o trabalho, além de garantir o seu andamento, realizando algumas de minhas tarefas no âmbito profissional.

Ao meu pai, Tarcísio Brandão da Cunha e à amiga Sandra Regina Bernardes, por abrir meus olhos perante a opção de desistência, incentivando-me a continuar até o fim.

Ao meu primo, Dr. Renato Cunha, por ajudar no desenvolvimento e na revisão da estrutura semântica e sintaxe do texto.

À empresa Conceito Tecnologia e à FAPESP, por fornecer acesso a todos os equipamentos necessários para o desenvolvimento do trabalho.

Ao Laboratório de Automação Agrícola e todos os seus profissionais que contribuíram com o trabalho, atuando como uma grande equipe interessada no desenvolvimento de todos aqueles que fazem parte do grupo. 
So you think you can tell Heaven from Hell, Blue skies from pain Can you tell a green field From a cold steel rail? A smile from a veil? Do you think you can tell? (Wish you were here - Pink Floyd - Roger Waters e David Gilmour) 
O presente trabalho teve como objetivo propor e testar uma metodologia para a realização de bindings dinâmicos na tecnologia LonWorks ${ }^{\circledR}$, com a finalidade de permitir que um Sistema Distribuído de Comunicação Telefônica Privada (SDCTP), também desenvolvido com a tecnologia LonWorks ${ }^{\circledR}$, realizasse seus enlaces telefônicos. Para tal, utilizou-se uma metodologia voltada para equipamentos embarcados e a visão de agentes reativos no desenvolvimento de cada dispositivo de rede, oferecendo uma solução única, prática e totalmente inédita na tecnologia LonWorks $^{\circledR}$ e nos dispositivos de PABX. Essa visão resultou no desenvolvimento de dispositivos inteligentes e totalmente autônomos, no que diz respeito aos seus processos internos, gerando resultados satisfatórios e mais eficientes do que se esperava com base nos requisitos levantados para o sistema SDCTP. Este trabalho é o ponto de partida e oferece uma base para o desenvolvimento de novas funcionalidades, tanto nos sistemas de telefonia atuais, quanto nas redes de controle.

Palavras-chaves: LonWorks ${ }^{\circledR}$, multi-agentes, Inteligência Artificial, sistemas distribuídos, PABX, telefonia, redes de controle 


\begin{abstract}
This presentation has the goal to propose and test a new method to implement dynamic bindings in LonWorks ${ }^{\circledR}$ technology, allowing a new Private Telephony Comunication Distributed System (SDCTP), also developed with LonWorks ${ }^{\circledR}$ technology, to make their telephone links. In order to do this, a method for developping embedded systems and the reactive agent view was applied for each different devices in this new system, thus offering a unique, practical and innovative solution for both, LonWorks ${ }^{\circledR}$ and PBX systems. This view allowed the implementation of intelligent and autonomous devices, specially in their internal process, thus granting satisfactory and more efficient results based on the SDCTP requirements. This work is the kick-off and the basis for developing new functions for telephone systems and control networks.
\end{abstract}

Keywords: LonWorks ${ }^{\circledR}$, multi-agents, Artificial Inteligency, distributed systems, PBX, telephony, control networks 


\section{LISTA DE ILUSTRAÇÕES}

Figura 1 - Arquitetura centralizada típica (ECHELON CORPORATION, 1999)......

Figura 2 - Arquitetura de uma rede de controle típica (ECHELON CORPORATION, 1999).

Figura 3 - Selo de certificação do produto pela LonMark (LONMARK

INTERNATIONAL, 2008).

Figura 4 - Hierarquia de endereços na rede LonWorks $₫$..

Figura 5 - Exemplo de interfaces de dispositivos de rede LonWorks ${ }^{\circledR} \ldots \ldots \ldots \ldots \ldots \ldots \ldots . . . . .34$

Figura 6 - Interface lógica da lâmpada no LonMaker.............................................45

Figura 7 - Interface lógica do interruptor no LonMaker.......................................46

Figura 8 - Representação de dispositivos descomissionados.................................4

Figura 9 - Dispositivos e seus respectivos blocos funcionais................................47

Figura 10 - Representação do binding entre a lâmpada e o interruptor......................48

Figura 11 - Dispositivos comissionados pelo LonMaker........................................49

Figura 12 - Tabela de endereços da lâmpada comissionada....................................49

Figura 13 - Tabela de configuração de variáveis da lâmpada...................................50

Figura 14 - Tabela de endereços e de variáveis do interruptor................................51

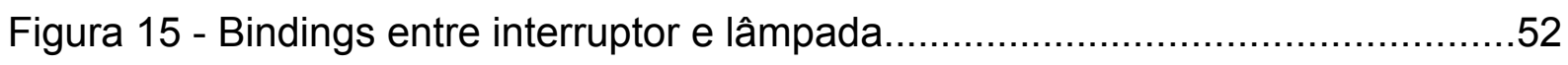

Figura 16 - Tabelas internas do interruptor e da lâmpada........................................52

Figura 17 - Estrutura de processamento do NeuronChip (ESTADOS UNIDOS, 1997)

Figura 18 - Memórias compartilhadas pelos processadores (ESTADOS UNIDOS,

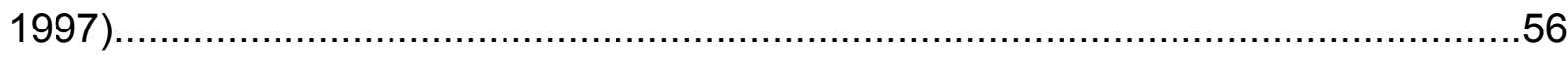

Figura 19 - Exemplo de mapas de memória (ESTADOS UNIDOS, 1997) .................57

Figura 20 - Esquema de montagem da lâmpada....................................................58

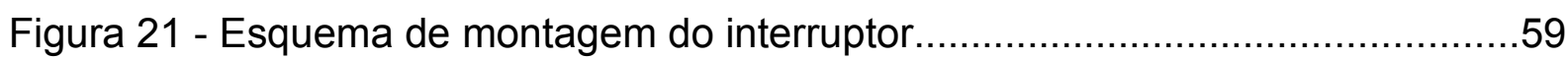

Figura 22 - Tela de exemplo da interface do NodeBuilder.....................................61

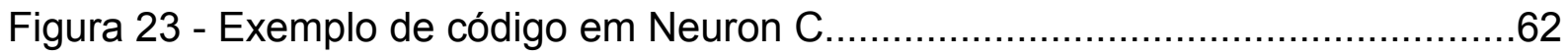

Figura 24 - Sistema de agendamento de eventos (ESTADOS UNIDOS, 1997).......63

Figura 25 - Topologia de uma PABX centralizado.............................................

Figura 26 - Topologia do PABX distribuído.........................................................

Figura 27 - Ampliação de ramais com o SDCTP................................................

Figura 28 - Cenário de exemplo de um sistema instalado......................................77

Figura 29 - Enlace virutal formado entre dois MTDs.............................................77 
Figura 30 - SDCTP com diversos enlaces simultâneos.

Figura 31 - O aspecto evolucionário do desenvolvimento de projetos de Engenharia (PAZ, 2002) 81

Figura 32 - Ligação física dos equipamentos .84

Figura 33 - Diagrama de seqüência do problema a ser solucionado. .88

Figura 34 - Interface de rede do MLT e do MTD. 90

Figura 35 - Possíveis tabelas após o binding entre o MLT e MTD. 91

Figura 36 - Diagrama de seqüência do handshake entre MLT e MDT. 94

Figura 37 - Fluxo de configuração dos bindings realizados. 97

Figura 38 - Diagrama de fluxo de dados para desfazer os bindings. 99

Figura 39: Exemplo do agente como uma camada extra no perfil funcional. 100

Figura 40 - Troca de mensagens de handshake entre MLT e MTD 102

Figura 41 - Retransmissão de mensagem pelo MLT 103

Figura 42 - Tabelas geradas pelo processo de bindings dinâmicos. 107

Figura 43 - Finalização do enlace telefônico 108

Figura 44 - Tabelas após desfazer as configurações de bindings. 109 


\section{Lista de Tabelas}

Tabela 1 - Tempo médio de uma operação de decisão dos seletores......................104 Tabela 2 - Levantamento do tempo médio para a realização de todo o processo. .105 Tabela 3 - Levantamento do processo de binding utilizando o LonMaker...............106 


$\begin{array}{ll}\text { BDI } & \text { Beliefs Desires Intention } \\ \text { CLP } & \text { Controlador Lógico Programável } \\ \text { CPU } & \text { Central Processing Unit } \\ \text { CSMA } & \text { Carrier Sense Multiple Access } \\ \text { EEPROM } & \text { Electrically-Erasable Programmable Read-Only Memory } \\ \text { FAPESP } & \text { Fundação de Amparo à Pesquisa do Estado de São Paulo } \\ \text { IO } & \text { Input/Output } \\ \text { LNS } & \text { LonWorks }{ }^{\circledR} \text { Network Services } \\ \text { ME1 } & \text { Módulo de Tronco E1 } \\ \text { MLT } & \text { Módulo de Linha Tronco } \\ \text { MRA } & \text { Módulo de Resposta Audível } \\ \text { MSG } & \text { Message } \\ \text { MTD } & \text { Módulo de Telefonia Digital } \\ \text { MGK } & \text { Módulo Gate Keeper } \\ \text { NV } & \text { Network Varible } \\ \text { OSI } & \text { Open Systems Interconnection } \\ \text { PABX } & \text { Private Automatic Branch Exchange } \\ \text { POO } & \text { Programação Orientada a Objetos } \\ \text { RAM } & \text { Random Access Memory } \\ \text { PSTN } & \text { Public System Telefony Network } \\ \text { SDCTP } & \text { Sistema Distribuído de Comunicação Telefônica } \\ \text { SNVT } & \text { Standard Network Varible Type }\end{array}$




\section{SUMÁRIO}

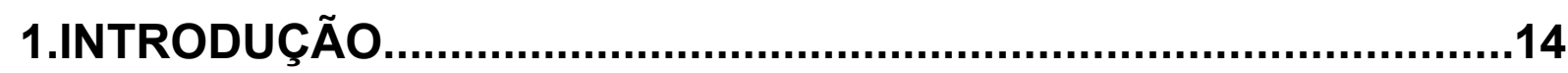

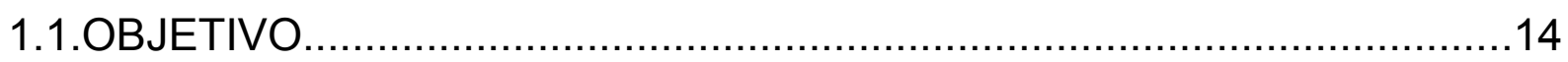

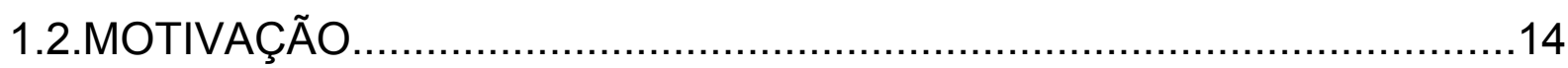

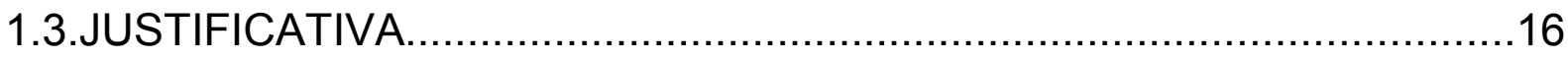

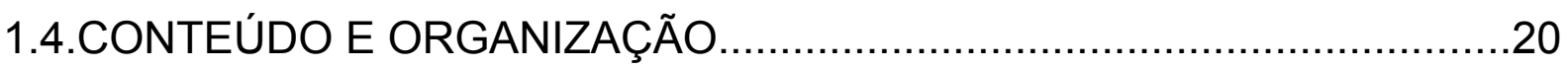

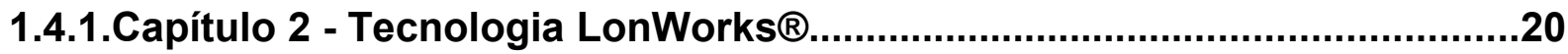

1.4.2.Capítulo 3 - O Paradigma Multiagentes........................................................

1.4.3.Capítulo 4 - Sistema Distribuído de Comunicação Telefônica Privada (SDCTP)

1.4.4.Capítulo 5 - Gerenciamento Dinâmico.......................................................21

1.4.5.Capítulo 6 - Conclusão............................................................................22

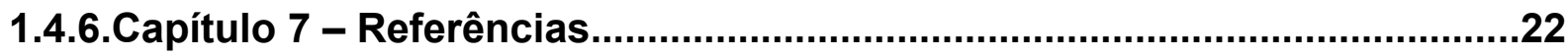

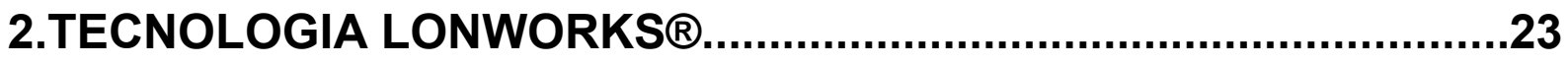

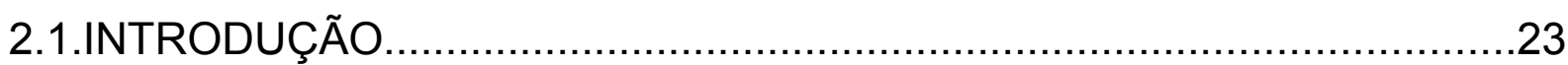

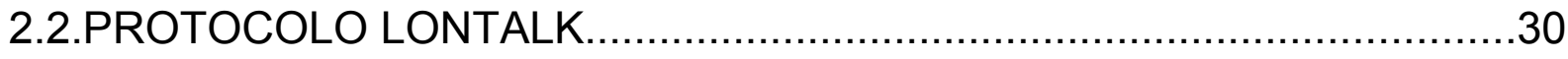

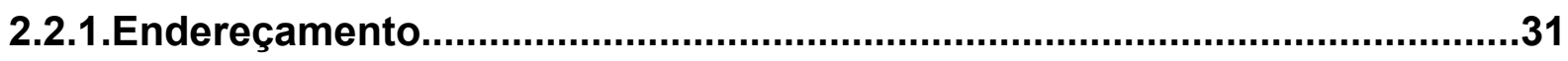

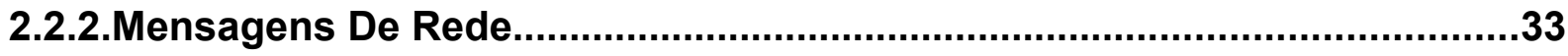

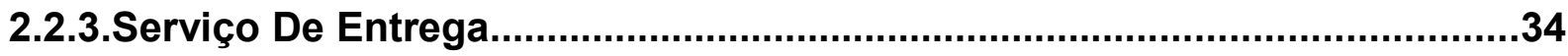

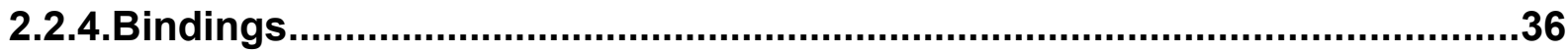

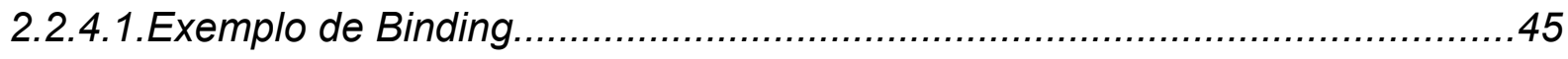

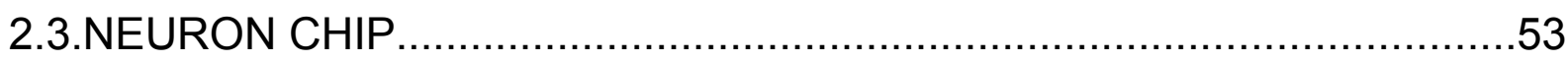

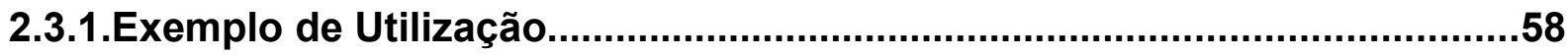

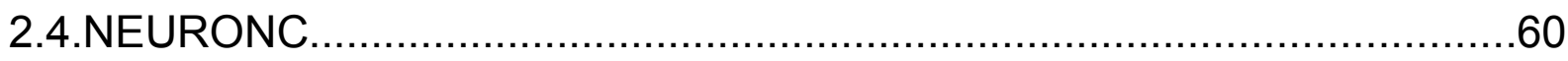

3.0 PARADIGMA MULTIAGENTES ............................................64

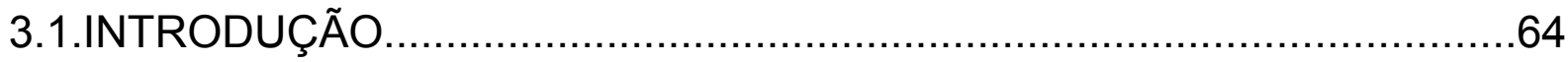

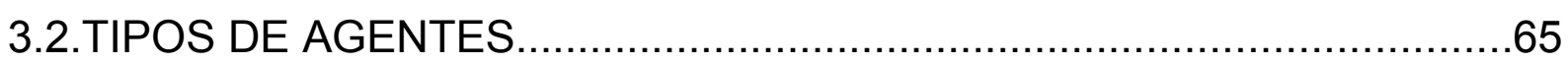

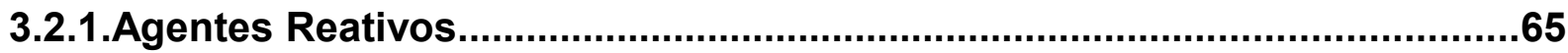

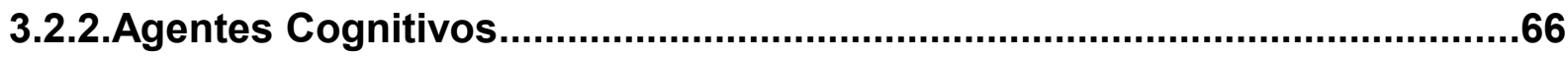

3.3.SOCIEDADES DE AGENTES E RESOLUÇÃO DISTRIBUÍDA DE

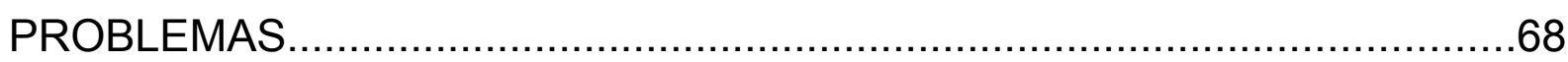




\section{SISTEMA DISTRIBUÍDO DE COMUNICAÇÃO TELEFÔNICA}

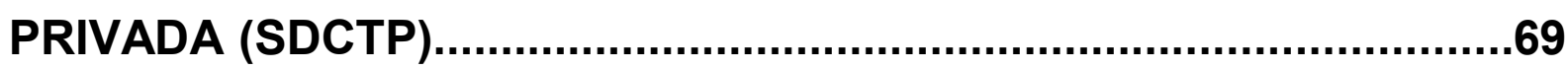

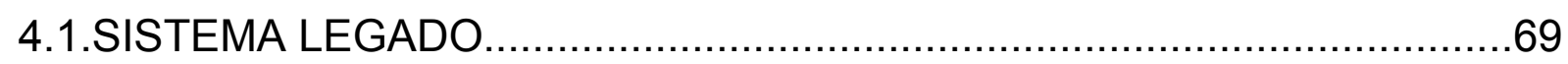

4.1.1.Funções Desempenhadas pelo PABX.....................................................71

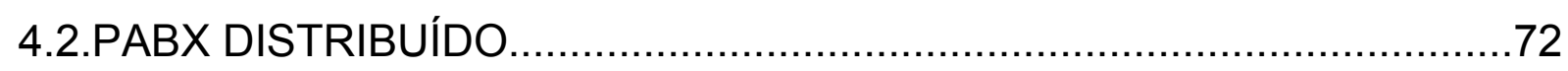

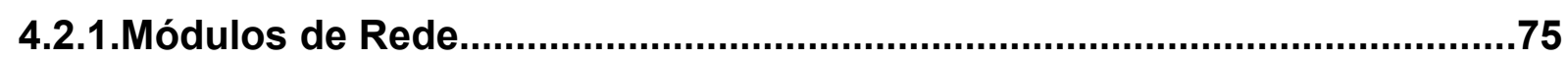

4.2.2.Enlaces Telefônicos.............................................................................76

5.GERENCIAMENTO DINÂMICO................................................80

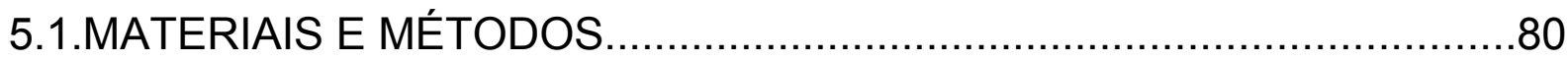

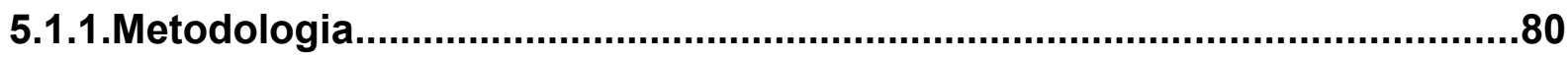

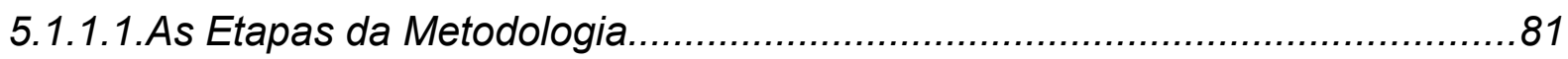

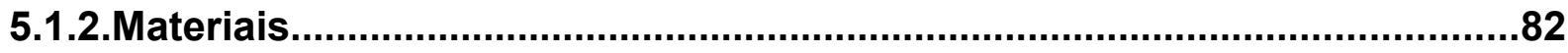

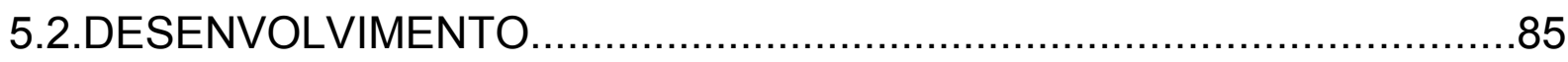

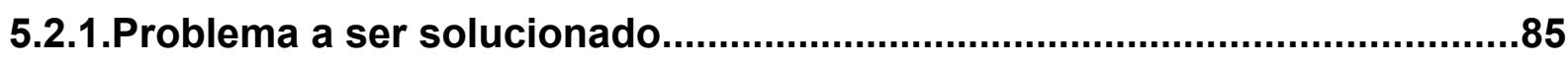

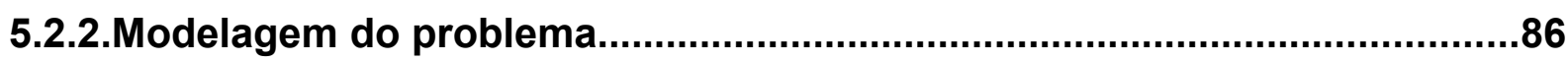

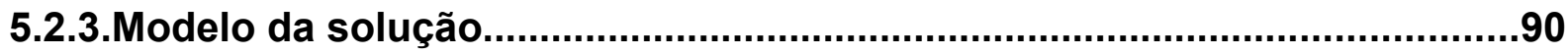

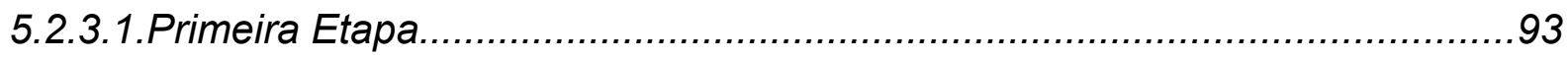

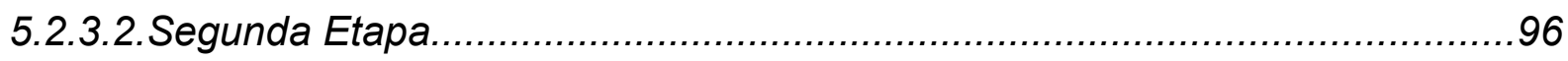

5.2.3.3.Terceira Etapa

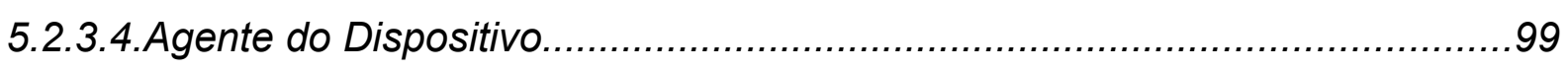

5.2.4.Análise dos Resultados e Discussão.......................................................101

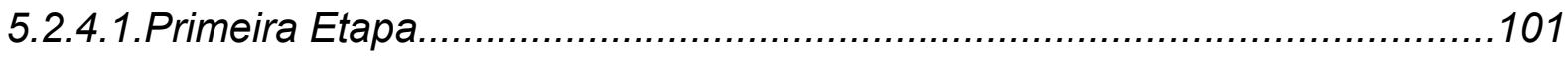

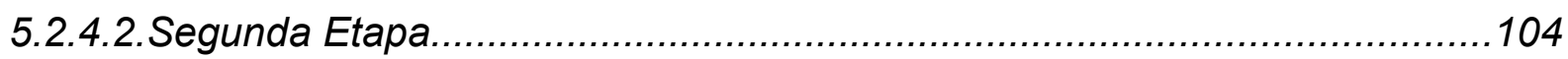

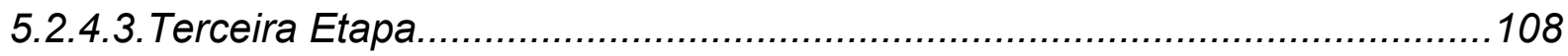

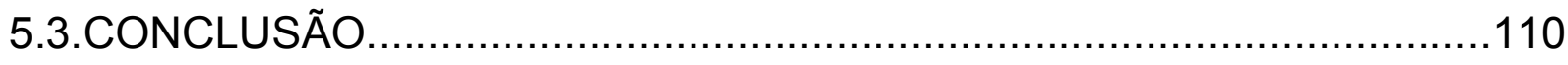

6.CONCLUSÃO................................................................................114

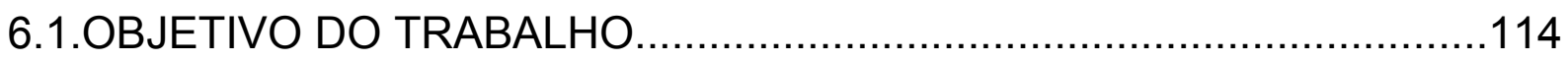

6.2.PRINCIPAL CONTRIBUIÇÃO DO TRABALHO.....................................114

6.3.OUTRAS CONTRIBUIÇÕES ......................................................116

6.4.PERSPECTIVAS DE CONTINUIDADE...............................................117

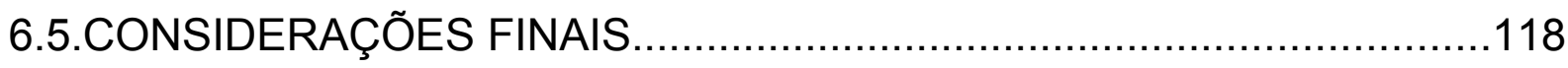

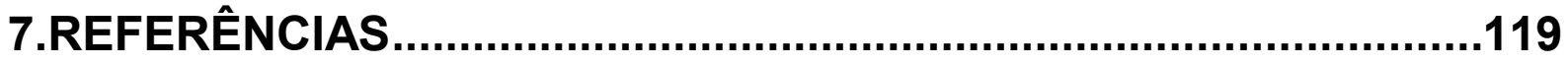




\section{INTRODUÇÃO}

\subsection{OBJETIVO}

O objetivo deste trabalho é propor e analisar uma solução, baseada no método de programação orientado a agentes (ZAMBONELLI; OMICINI, 2004; SHOHAM, 1991), para o desenvolvimento de dispositivos inteligentes de um Privated Automatic Branch Exchange (PABX) distribuído, utilizando a tecnologia LonWorks ${ }^{\circledR 1}$, capazes de se auto-gerenciar, de forma dinâmica, em um ambiente previamente configurado.

\subsection{MOTIVAÇÃO}

Nos últimos anos, o paradigma de concepção de sistemas de automação vem sendo modificado com a substituição gradual das arquiteturas centralizadas e proprietárias, por arquiteturas abertas e distribuídas (HUR; KIM; PARK, 2005; XIE; PU; MOORE, 1998).

Essa mudança de paradigma traz algumas vantagens para essas novas instalações, uma vez que os dispositivos de rede como, por exemplo, sensores ou atuadores, passam a dispor de capacidade de processamento local e de comunicação. Eles se tornam nós de uma rede especialmente projetada para essa finalidade, passando a integrar o conceito de redes de controle.

Uma dessas vantagens é uma redução significativa na quantidade de cabos utilizados e custos associados (ALVES FILHO, 2001), visto que com essa topologia não existe mais um concentrador de sinais exigindo que todo o cabeamento de sensores e atuadores sejam levados até ele.

Outra vantagem é o maior potencial para se conceber sistemas mais confiáveis. Em um sistema centralizado, se o processador central deixar de operar, todo o sistema também ficará inativo; já com o processamento distribuído, mesmo havendo a falha em algum nó da rede, o restante do sistema poderá continuar funcionando, com alguma degradação (ALVES FILHO, 2001).

O uso de tecnologias abertas traz a vantagem da independência de um único fabricante, podendo-se compor sistemas com as partes que melhor atendam às necessidades, tanto do ponto de vista técnico como do econômico. Essa

1 Um dos resultados do projeto de pesquisa associado à tese do doutorando da Escola Politécnica, Miguel dos Santos Alves Filho. Previsão para entrada com o pedido de patente: 2009. 
característica se reflete também em outros aspectos importantes para os usuários. A instalação e manutenção dos sistemas, também passam a contar com mais opções de prestadores de serviços (ECHELON CORPORATION, 2007), além de diversas ferramentas de suporte de fornecedores diferentes, necessárias à manutenção e ampliação (HUR; KIM; PARK, 2005).

Após o sistema entrar em funcionamento, muitas vezes é necessário realizar alguns procedimentos de manutenção, como por exemplo, a troca de dispositivos devido a falhas. Da mesma forma, pode ocorrer a necessidade de expansão do sistema instalado para atender a novas necessidades ou ampliar os seus recursos.

Um sistema convencional, com arquitetura centralizada e proprietária, é alterado através do uso de ferramentas também proprietárias, o que obriga a quem possui o sistema, em geral, a se tornar dependente do instalador ou desenvolvedor inicial, ou criar a sua própria estrutura para tal, envolvendo a capacitação de equipe e aquisição da infra-estrutura necessária (ALVES FILHO, 2001).

Outro problema desse tipo de sistema, diz respeito à otimização do investimento em equipamentos. Ocorre muitas vezes que quando se deseja ampliar um sistema, com uma determinada quantidade de pontos de entradas e saídas, pode não existir um módulo de expansão a ser adquirido, que possua uma quantidade de pontos próxima ao desejado. Neste caso, devem-se adquirir módulos com recursos acima do necessário, envolvendo maiores custos (ECHELON CORPORATION, 2007).

Tais problemas não ocorrem em sistemas baseados em redes de controle, onde normalmente os módulos atendem a um ou poucos pontos, por não possuírem uma grande capacidade de processamento (ALVES FILHO, 2001).

Acontece que, o projeto e manutenção de sistemas com arquitetura distribuída requerem outros cuidados, como por exemplo, a identificação lógica única de cada nó presente na rede de controle, que pode ser atendida apenas com recursos de ferramentas específicas, recursos estes que devem ser sempre levado em conta no caso de uma troca de dispositivos.

Nos sistemas centralizados, alterações na programação e 
configuração dos sistemas envolvem o equipamento central. Já nos sistemas distribuídos, é necessário atualizar a programação e configuração de diversos dispositivos individualmente, além de garantir que a interação dos mesmos, com os demais continue coerente, e que o sistema como um todo atenda aos novos requisitos (ALVES FILHO, 2001).

O pesquisador Me. Miguel dos Santos Alves Filho, utilizou essas vantagens de sistemas distribuídos e de redes de controle citadas acima, para o desenvolvimento de um PABX distribuído, baseado na tecnologia LonWorks ${ }^{\circledR}$ (com o apoio da FAPESP, projeto número 05/56045-6), no contexto de suas pesquisas de doutorado e de desenvolvimento tecnológico.

Esse PABX, chamado de Sistema Distribuído de Comunicação Telefônica Privada (SDCTP), tem como característica a distribuição de dispositivos em uma rede, e todas as funcionalidades contidas em um PABX convencional, agregando escalabilidade, custo efetivo e flexibilidade para os sistemas de telefonia privados, além da integração entre uma interface usuário-máquina através de voz e o sistema de automação predial da empresa.

Ele utiliza a tecnologia LonWorks $^{\circledR}$ para interligar os dispositivos como os telefones, linhas troncos, secretárias eletrônicas, entre outros. Através dessa rede, serão gerenciados os enlaces telefônicos e será realizada a passagem de voz durante uma conversa, por exemplo.

Tendo esse cenário em vista, a configuração estática dos nós, uma característica da rede LonWorks $^{\circledR}$, deve ser suplantada de forma a permitir que configurações dinâmicas sejam realizadas, pois enlaces telefônicos devem ser feitos e desfeitos a todo momento.

Portanto, a motivação desse trabalho é viabilizar a criação de enlaces telefônicos de forma dinâmica para o SDCTP.

\subsection{JUSTIFICATIVA}

Os sistemas de automação, baseados em redes de controle, eliminam diversos problemas associados às tecnologias convencionais (CANOVAS, 2006; ECHELON CORPORATION, 2007).

Tomando-se como exemplo, a distância máxima entre os sensores 
que normalmente fornecem sinais elétricos analógicos para a representação das grandezas, e o equipamento que recebe tal sinal, condicionando-o e convertendo-o para a forma digital (TANI, 2006).

A degradação do sinal analógico é proporcional à distância, reduzindo a precisão das medições e muitas vezes tornando-as inaceitáveis em alguns casos (CANSADO, 2003).

Com o advento das redes de controle, em um primeiro momento, passou-se a fazer uso de nós, que simplesmente coletavam informações de sensores, convertendo-as para a forma digital e enviando-as para outros dispositivos com maior capacidade de processamento, ainda caracterizando um sistema hierárquico com centralização das decisões (ALVES FILHO, 2001). Observa-se com essa topologia lógica, que apesar se de utilizar uma rede de controle, o sistema ainda caracteriza uma arquitetura centralizada, visto que há um concentrador de informações.

Posteriormente, passou-se a utilizar nós com maior capacidade de processamento, e as atividades, que antes eram executadas somente em algum nó central, de maior capacidade, foram distribuídas por completo entre os diversos nós da rede de controle, evoluindo para um sistema verdadeiramente distribuído (ALVES FILHO, 2001).

Apesar das vantagens advindas, os sistemas baseados em redes de controle exigem implementações mais complexas: torna-se necessário algum protocolo robusto e eficiente que permita a comunicação entre os dispositivos, assim como uma forma de identificação dos mesmos, como por exemplo (ECHELON CORPORATION, 2007).

Para suprir essa necessidade, surgiram diversos protocolos de comunicação para essa categoria de rede, alguns com tecnologia aberta, podendose citar o Profibus, o Modbus, o Fieldbus e o LonTalk (ALVES FILHO, 2001).

O padrão Modbus utiliza o par trançado de fios como meio de comunicação (padrão RS485) e a filosofia mestre-escravo (MODBUS-IDA, 2007).

O protocolo Fieldbus é capaz de suportar diversos meios físicos, como o par-trançado, e a comunicação entre os dispositivos é realizada ponto-aponto (FIELDBUS FOUNDATION, 2007). 
Por fim, o protocolo LonTalk, que além suportar diversos meios de transmissão (além de par trançado), como fibra óptica, infra-vermelho, rádiofreqüência e rede elétrica; permite que a comunicação entre seus dispositivos seja realizada ponto-a-ponto, de um dispositivo para muitos, (multicast) ou de um dispositivo para todos (broadcast) (ECHELON CORPORATION, 1999).

Um dos meios físicos de comunicação mais utilizado em sistemas de automação predial com a tecnologia LonWorks ${ }^{\circledR}$ é o par trançado, utilizado em redes com topologia planejada e estruturada, ou com topologia livre (como barramento, estrela ou laço). Atualmente é homologada na Comunidade Européia e na China como padrão de automação predial, pois oferece flexibilidade e confiabilidade (ECHELON CORPORATION, 1999; 2007; CONCEITO TECNOLOGIA, 2009).

Em se tratando do protocolo LonTalk, os nós possuem um endereço físico que jamais se repete (o Neuron ID) definido pelo fabricante, e um endereçamento lógico associado durante a sua configuração, semelhante ao que ocorre nas redes de computadores com o protocolo TCP/IP (ECHELON CORPORATION, 1999).

No caso de uma instalação inicial, os dispositivos ainda não estão configurados de forma a permitir a troca de mensagens associadas à aplicação; somente podem receber mensagens de gerenciamento. A única informação que possuem são seus endereçamentos físicos (ECHELON CORPORATION, 2007).

Para que a rede passe a funcionar, é necessário a utilização de uma ferramenta de configuração de rede e a execução de um processo, onde será atrelado a cada endereço físico, um endereçamento lógico (ECHELON CORPORATION, 2003a).

O protocolo LonTalk exige que sejam configurados o domínio do dispositivo, a subrede a qual ele pertence e o número do dispositivo dentro da subrede (ECHELON CORPORATION, 2002).

Após a configuração do endereço lógico do dispositivo, este é programado com as informações que o possibilite comunicar-se com os outros dispositivos, recebendo e enviando mensagens de rede. Na tecnologia LonWorks ${ }^{\circledR}$, esse último processo é denominado binding (que será melhor descrito nas próximas sessões). 
Em uma rede recém desenvolvida há que se popular, com uma ferramenta especial, um banco de dados, que é uma imagem de como a rede e seus nós estão configurados (ECHELON CORPORATION, 2003a).

Assim, caso um dispositivo necessite ser trocado, basta que o usuário informe à ferramenta de configuração, o endereço do dispositivo que será trocado e o endereço físico do novo dispositivo.

A partir de então, toda a configuração do dispositivo antigo será passada para o dispositivo novo, e o primeiro será eliminado da rede e do banco de dados, enquanto que os demais nós não perceberão que uma troca foi realizada (ECHELON CORPORATION, 2003a).

Os procedimentos descritos até então, destacam as três principais dificuldades no desenvolvimento de sistemas baseados em redes de controle LonWorks $^{\circledR}$.

A primeira, diz respeito às ferramentas de configuração: o usuário deve possuí-las e estar treinado a utilizá-las.

A segunda, está na manutenção da base de dados denominada LonWorks $^{\circledR}$ Network Services (LNS), gerada durante o período de instalação, que será indispensável em qualquer manutenção futura (ECHELON CORPORATION, 2003a).

A terceira, a ampliação da rede ou troca de dispositivos, também exige a utilização da ferramenta de configuração e da base de dados inicial (ECHELON CORPORATION, 2003a).

Apesar do processo de configuração dos dispositivos e da intercomunicação entre eles, depender da utilização de ferramentas especializadas, de um banco de dados e de um especialista para realizar todo o processo, a característica estática das configurações desses dispositivos é inerente à tecnologia, de acordo como essa tecnologia foi desenvolvida e a finalidade da sua aplicação.

A forma estática atual de configuração e comissionamento dos dispositivos, além da dependência total de ferramentas de software e mão-de-obra, podem inviabilizar o desenvolvimento do SDCTP, uma vez que muitas conexões telefônicas deverão ser feitas e desfeitas rapidamente.

Portanto, a pesquisa realizada nesta dissertação será de grande 
importância para o SDCTP, fornecendo um meio que possibilita a realização de enlaces telefônicos na tecnologia LonWorks ${ }^{\circledR}$ e configuração dos equipamentos de telefonia.

A escolha em utilizar técnicas de Inteligência Artificial para a solução deste problema reside na característica distribuída do SDCTP, que se equipara às características de um sistema Multiagentes, com unidades autônomas para tomadas de decisão e a comunicação entre elas.

\subsection{CONTEÚDO E ORGANIZAÇÃO}

A partir deste item é detalhado o conteúdo contido em cada capítulo subseqüente.

\subsubsection{Capítulo 2 - Tecnologia LonWorks ${ }^{\circledR}$}

Primeiramente, será apresentada uma visão geral da tecnologia LonWorks $^{\circledR}$, descrevendo-se um pouco de sua história, sua estrutura básica e protocolo de comunicação. Em seguida, serão discutidas algumas funcionalidades que esse protocolo oferece, como a forma de endereçamento na rede dos dispositivos, diferenciando-o dos demais, mesmo que com as mesmas funcionalidades.

Depois, será apresentado como é realizada a troca de mensagens entre os nós, sejam elas mensagens de aplicação ou de gerenciamento, demonstrando-se os tipos de mensagens possíveis dentro de uma rede. Neste ponto, também é apresentada a notação e a padronização utilizada pela tecnologia, e a classificação dos dispositivos conforme a sua interface. Logo em seguida, serão apresentados os tipos de serviços, que podem ser utilizados durante a troca de mensagens entre nós, e como funcionam os bindings, que configuram a interação entre os dispositivos.

Por fim, será apresentado o NeuronChip, utilizado para o desenvolvimento dos dispositivos (nós), dando-se um foco nas suas características funcionais e fazendo uma breve apresentação das suas ferramentas de desenvolvimento. 


\subsubsection{Capítulo 3 - O Paradigma Multiagentes}

Este capítulo apresenta um dos ramos da Inteligência Artificial, que será utilizado como método para possibilitar atingir o objetivo proposto neste trabalho. Será apresentado o que significa esse novo paradigma, e como ele se relaciona com as formas mais conhecidas de métodos de desenvolvimento, como por exemplo, a orientação a objetos.

Tendo-se em mente esse novo paradigma, será apresentado o método como podem ser classificados os agentes, levando-se em conta as suas características, funcionalidades e necessidades. Posteriormente é apresentado como esses agentes podem trabalhar em conjunto, gerando sociedades complexas autônomas, com ou sem uma finalidade específica. Neste mesmo contexto, é apresentada a visão de uma sociedade de agentes um pouco mais restrita, com a finalidade de resolver um único problema, gerando a resolução distribuída de problemas.

\subsubsection{Capítulo 4 - Sistema Distribuído de Comunicação Telefônica Privada (SDCTP)}

Neste capítulo será inicialmente apresentado o funcionamento do SDCTP, que é um PABX distribuído utilizando a tecnologia LonWorks ${ }^{\circledR}$.

Primeiramente, será apresentado o contexto do trabalho, ou seja, o objetivo do projeto de pesquisa e como ele se insere no contexto acadêmico. Também serão apresentadas vantagens da nova proposta em relação ao PABX convencional e uma visão geral de seu funcionamento.

Posteriormente, será apresentado o cenário específico que será utilizado como estudo de caso e que motivou o desenvolvimento deste trabalho, dado-se ênfase ao problema que será posto em questão, suas características e requisitos necessários a serem levados em conta na solução.

\subsubsection{Capítulo 5 - Gerenciamento Dinâmico}

Este capítulo apresentará o trabalho de pesquisa desenvolvido, descrevendo de forma detalhada, os requisitos que foram considerados e premissas adotadas para o desenvolvimento da solução proposta. Em seguida são 
apresentados os testes utilizados para validação do trabalho, levando-se em conta os requisitos adotados. Neste ponto serão apresentadas as métricas e a justificativa pelas quais elas foram adotadas, também seconsiderando os equipamentos disponíveis para o desenvolvimento.

Posteriormente, tanto 0 planejamento adotado para o desenvolvimento do trabalho como a metodologia utilizada, serão explicitados. São descritos os diagramas de fluxo, as máquinas de estado, os diagramas de seqüência e etc.

$\mathrm{Na}$ seqüência, serão apresentados e discutidos os resultados obtidos com essa solução específica, conforme as métricas estabelecidas anteriormente neste mesmo capítulo. Aqui também será realizada uma verificação de como a solução atende aos requisitos do problema e uma discussão a respeito da solução oferecida.

\subsubsection{Capítulo 6 - Conclusão}

Este capítulo comenta os resultados obtidos.

\subsubsection{Capítulo 7 - Referências}

Este capítulo apresenta a lista de todas as referências utilizadas. 


\section{TECNOLOGIA LONWORKS ${ }^{\circledR}$}

Atualmente, vive-se em um mundo onde a grande miniaturização dos equipamentos eletrônicos atrelada à grande produção em massa de dispositivos dotados de capacidade de processamento, permite que existam aparelhos chamados de "inteligentes" de pequeno porte, espalhados pelos ambientes.

Além disso, sabe-se que dispositivos que não interagem entre si e não têm alguma forma de comunicação, acabam por ter a sua utilidade prejudicada: tem-se um computador sem acesso à Internet, que não supre grande parte das necessidades do usuário, como exemplo disso.

Dessa forma, a comunicação entre dispositivos se torna tão necessária quanto os próprios dispositivos, pois é através dessa comunicação que eles conseguem trocar informações, formando uma base de conhecimento ainda maior, para que possam desempenhar suas funções previstas com maior eficiência, sendo invisível ao usuário, aproximando cada vez mais os sistemas aos preceitos da Computação Pervasiva (HANSMANN, 2003).

Uma das redes de controle que se destina a implementar tais sistemas, e que vem ganhando mais destaque nos últimos anos, é a LonWorks ${ }^{\circledR}$, que será descrita no próximo item.

\subsection{INTRODUÇÃO}

Conforme já comentado, grande parte dos sistemas de automação utilizados atualmente é baseada em arquitetura centralizada, onde há um concentrador de informações, como os Controladores Lógicos Programáveis (CLP), que coletam todos os dados dos dispositivos de entrada, realizam o processamento previsto, e geram os acionamentos para os dispositivos de saída.

Um grande problema dessa arquitetura é a necessidade de que todos os dispositivos de entrada e saída (sensores e atuadores) devam estar ligados diretamente aos dispositivos controladores, requerendo muitos fios e tornando a instalação muito custosa (ECHELON CORPORATION, 1999).

Neste tipo de arquitetura, criam-se gargalos tanto de eficiência como de segurança, em relação ao seu funcionamento, ou seja, o sistema será tão eficiente quanto o elemento central permitir. 
A Figura 1 apresenta a arquitetura básica típica encontrada em tais sistemas:

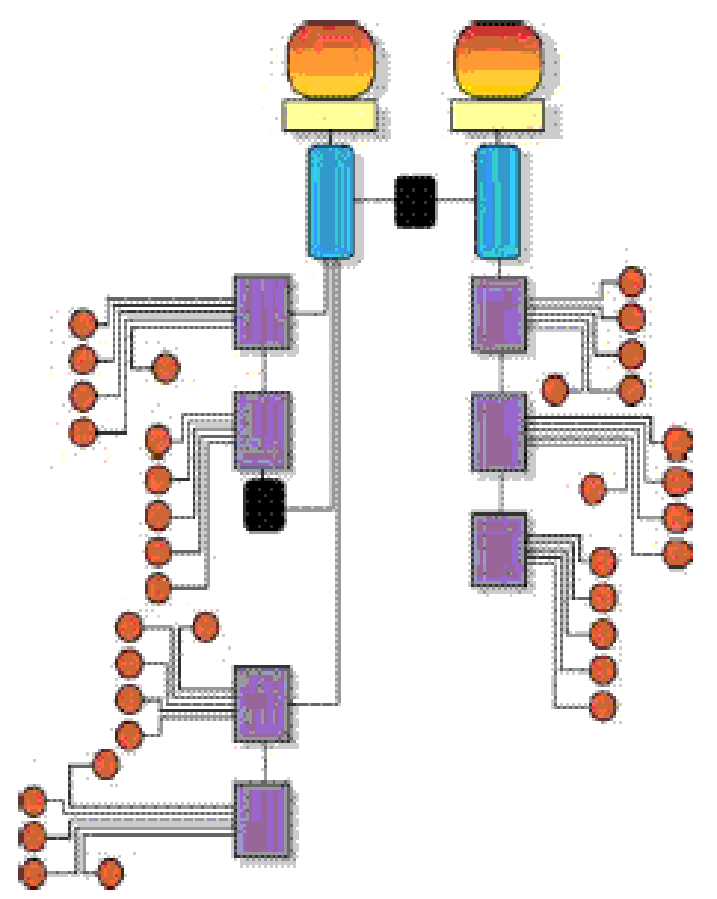

Figura 1 - Arquitetura centralizada típica (ECHELON CORPORATION, 1999)

Naturalmente, a confiabilidade do sistema com arquitetura centralizada é muito dependente do elemento central, que caso falhe, inviabiliza o funcionamento de todo o sistema (ALVES FILHO, 2001).

Já há algum tempo, algumas empresas notáveis, como a Siemens e a Johnsons Control, fornecem soluções completas, baseadas em redes de controle; porém com tecnologia fechada.

Apesar de se encontrar padrões abertos já disponíveis, como o Fieldbus e o Modbus, a grande maioria das empresas utiliza protocolos de comunicação, interface usuário-máquina e métodos de programação baseados em tecnologia proprietária e fechada, o que passou a ser um grande problema para os usuários (MODBUS-IDA, 2007; FIELDBUS FOUNDATION, 2007).

Ainda hoje é muito difícil conseguir integrar equipamentos de fornecedores diferentes. Ocorrem, freqüentemente, casos de empresas que acabam perdendo todo um sistema já instalado, quando o fornecedor original dos 
equipamentos de controle já não se encontra mais no mercado e não há meios de obter informações a respeito do funcionamento desses equipamentos e seus protocolos de comunicação (ECHELON CORPORATION, 1999; HUR; KIM; PARK, 2005).

Além disso, há um enorme impacto no que se refere ao relacionamento de um cliente e seu fornecedor, pois o primeiro estará totalmente dependente de preços, prazos de entrega, qualidade e serviços do segundo, nem sempre vantajosos ao primeiro.

Cada vez mais se verifica a tendência em se utilizar protocolos padronizados, como ocorre em redes de dados (como a Internet, que utiliza o protocolo TCP/IP). Isso se repete em relação a redes de controle com tecnologia aberta. (XIE; PU; MOORE, 1998).

A Figura 2 ilustra distribuições típicas de nós nessas redes:

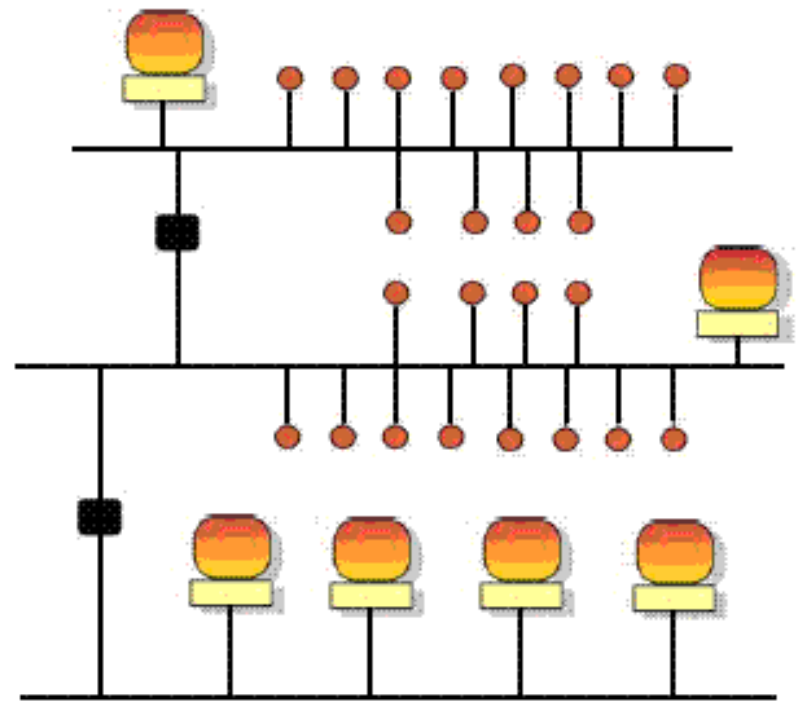

Figura 2 - Arquitetura de uma rede de controle típica (ECHELON CORPORATION, 1999)

Os dispositivos possuem capacidade própria de processamento e de comunicação direta entre eles. Esse fato traz algumas implicações, como a distribuição das funções dos programas e algoritmos de controle entre os nós, devendo cada um responsabilizar-se por parte do processamento, a partir de informações recebidas de outros módulos (XIE; PU; MOORE, 1998).

Outro ponto importante, diz respeito à robustez do sistema: mesmo 
que alguns dispositivos deixem de operar, o restante do sistema pode continuar a operar, com redução de funcionalidades.

A distribuição da inteligência leva a uma natural modularização, sendo que a programação de cada nó tende a ser muito simples quando comparada à programação de um CLP, por exemplo. Cada nó pode ser tratado como um objeto, semelhante ao que ocorre em Programação Orientada a Objetos (POO).

Dessa forma, alternando-se de uma arquitetura centralizada para uma arquitetura distribuída, os sistemas podem se tornar mais robustos, modulares e escaláveis.

Um grande impulso ao uso de redes de controle ocorreu a partir da abertura do padrão utilizado na tecnologia LonWorks ${ }^{\circledR}$, desenvolvida no início da década de 90: o protocolo LonTalk foi normatizado, recebendo a denominação ANSI/EIA 709.1 (ECHELON CORPORATION, 1999).

LonWorks $^{\circledast}$ caracteriza uma tecnologia, envolvendo um conjunto de ferramentas para desenvolvimento e um protocolo aberto de comunicação. Atualmente este protocolo é adotado em muitos tipos de sistemas, podendo-se destacar: sistemas de automação predial; sistemas de automação embarcados; controle de freios pneumáticos em ferrovias; sistemas de controle interno de aeronaves; e linhas de produção de dispositivos semi-condutores (ECHELON CORPORATION, 2007).

Por se tratar de um padrão aberto, a interoperabilidade corresponde a um novo apelo, pois nós de fabricantes diferentes podem se comunicar e serem incorporados em uma mesma rede. Apesar de ambos serem protocolos que envolvem a troca de mensagens em uma rede de dispositivos, existem algumas diferenças entre o protocolo LonTalk e aqueles utilizados em redes de dados, como o TCP/IP.

Diferentemente das redes de dados, em uma rede de controle existem algumas características e requisitos próprios, como por exemplo, o pequeno tamanho das mensagens e o tempo de resposta. Alguns dos requisitos que são supridos por esse protocolo são: a comunicação segura, a comunicação freqüente e a comunicação confiável entre dispositivos. Nas aplicações de controle não pode haver perdas e degradação de dados, e nem a impossibilidade de comunicação 
entre dispositivos (ECHELON CORPORATION, 1999; TSE; CHAN; LAI, 2003).

Pode se verificar um exemplo de todas essas necessidades nas aplicações médicas ou nos sistemas embarcados, onde o dano causado por uma falha pode ser grande. Esses requisitos exigem que, diferentemente de uma rede TCP/IP, uma rede LonWorks $^{\circledR}$ seja determinística (ECHELON CORPORATION, 1997).

Outra característica do protocolo LonTalk é a sua otimização para a troca de mensagens curtas entre dispositivos (que predominam em sistemas de controle e automação), além de garantir que qualquer um deles possa se comunicar com qualquer outro dispositivo da rede (ECHELON CORPORATION, 1997).

Uma variedade de serviços também é fornecida por esse protocolo, como o que permite que os dispositivos de rede se comuniquem sem que a topologia da rede seja conhecida por qualquer um deles, além de fornecer diferentes tipos de tratamento, como por exemplo, mensagens que são repetidas na rede um certo número de vezes para diminuir a probabilidade dela não ser recebida, ou mensagens que são enviadas até que cada receptor responda com uma mensagem de confirmação de recebimento.

Este protocolo foi desenvolvido de acordo com o modelo de camadas OSI e fornece serviço em seis das suas sete camadas. A seguir apresentase uma descrição resumida dos serviços oferecidos em cada camada (ECHELON CORPORATION, 2002):

1. Física: o protocolo garante que um bit enviado seja reconhecido como o mesmo bit por todos os dispositivos receptores. Este protocolo é independente do meio de comunicação.

2. Enlace: define os modos de acesso ao meio de transmissão e da codificação dos dados, garantindo o seu uso de forma eficiente: estipulando quando o dispositivo pode enviar um frame de dados; a forma como o destino os reconhece e os recebe; e também as prioridades de acesso ao meio para a transmissão.

3. Rede: define como é feito o endereçamento, a forma de nomeação dos dispositivos e as rotas quando a origem e o destino se encontrarem em canais de comunicação diferentes.

4. Transporte: garante a entrega confiável dos pacotes que contêm 
informações, além de detectar e ignorar mensagens duplicadas.

5. Sessão: adiciona controle de troca de dados pelas camadas mais inferiores, assim como fornece suporte a ações remotas, permitindo que um cliente faça uma requisição a um servidor. Implementa também, um sistema de autenticação, verificando se um determinado cliente está apto a receber a informação requisitada.

6. Apresentação: fornece uma estrutura aos dados que estão sendo trocados pelas camadas inferiores. Elas podem ser codificadas como variáveis de rede, mensagens de aplicações etc. Aqui são definidas as Standard Network Variable Types (SNVTs), que garantem a interoperabilidade entre os fornecedores.

A camada sete não está especificada no protocolo, para permitir que o usuário crie a aplicação de acordo com a sua necessidade (ECHELON CORPORATION, 2002).

Um conceito importante introduzido pelo protocolo LonTalk, é o binding. Neste ponto há uma grande diferença em relação aos sistemas de automação convencionais, pois o valor a ser obtido ou enviado agora deixa de estar atrelado a um dispositivo físico (ponto de entrada ou saída), e passa a ser considerado como uma variável de rede, que pode ser fornecida por qualquer dispositivo com a mesma funcionalidade, estrutura de dados e características (ECHELON CORPORATION, 1999, 2007).

O binding é o ato de indicar a um dispositivo receptor qual a variável que ele deve obter da rede e a sua origem. Neste processo, é informado ao receptor um número único que identifica esta variável na rede. Caso esta variável ainda não tenha um identificador, neste mesmo processo, é informado ao dispositivo emissor qual ele deve utilizar.

O processo de programação e manutenção que envolva a troca de dispositivos responsáveis por fornecer determinada automação, ou ainda, alterar o tipo de informação recebida, é realizado através de ferramentas de gerenciamento de rede, que permitem a alteração dos endereços lógicos respectivos, deixando de envolver procedimentos de troca física de dispositivos.

Considerando que o desenvolvimento de redes LonWorks ${ }^{\circledR}$ está atrelado a um órgão mundial responsável por criar padrões para o formato, tipo e 
unidade da variável de rede, as vantagens de utilização desse conceito deixam de estar situadas apenas nos processos de desenvolvimento e manutenção. Os processos internos que são realizados dentro dos dispositivos passam a ser encapsulados, possibilitando ao usuário selecionar fabricantes diferentes que forneçam a mesma informação, mas que podem possuir resultados diferentes.

Devido a esse novo conceito de interfaces e encapsulamento em redes de controle, pode-se considerar os seus dispositivos como unidades lógicas e independentes, semelhantes aos objetos de programação, onde as mensagens trocadas podem ser comparadas à chamada de métodos (ECHELON CORPORATION, 1995a, 2007; XIE; PU; MOORE, 1998).

Com essa ótica, abre-se espaço para a utilização de técnicas da inteligência artificial, em redes de controle e automação. Nestes sistemas, os objetos são envolvidos com uma nova camada, que lhes acrescenta, por exemplo, objetivos e conhecimento, ou seja, tornam esses objetos entidades autônomas.

Para finalizar, cabe destacar que essa organização mundial, chamada LonMark, é formada por fabricantes, desenvolvedores e usuários da tecnologia LonWorks ${ }^{\circledR}$ criada com a finalidade de gerenciar estes padrões utilizados (LONMARK INTERNATIONAL, 2008). Ela é responsável por criar desde variáveis padrões, as chamadas SNVTs até interfaces padrões conforme a classe de dispositivo e sua aplicação. Ela também certifica os produtos criados e submetidos à análise dando a garantia de que eles poderão ser totalmente integrados com outros dispositivos também certificados.

A Figura 3 apresenta o selo utilizado em produtos certificados pela LonMark:

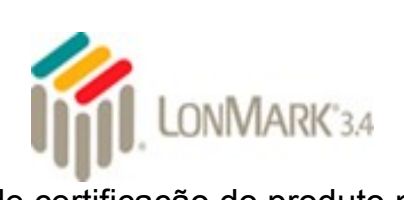

Figura 3 - Selo de certificação do produto pela LonMark

(LONMARK INTERNATIONAL, 2008)

Portanto todo fabricante que tiver a intenção de que seu produto seja integrado com o produto de outros fabricantes, deve seguir os padrões estabelecidos pela LonMark. E como forma de garantir ao seu cliente que essa interoperabilidade realmente existe, o produto deverá ser submetido à análise de uma equipe pela LonMark. 


\subsection{PROTOCOLO LONTALK ${ }^{2}$}

Conforme já citado anteriormente, o protocolo utilizado pelos dispositivos LonWorks ${ }^{\circledR}$ é o LonTalk (ou EIA 709.1), sendo totalmente aberto e passível de ser implementado em qualquer microprocessador ou microcontrolador. Atualmente, tem-se como mais popular o NeuronChip, que é um microcontrolador desenvolvido pela Motorola em conjunto com a Echelon fabricado e comercializado pela Toshiba e pela Cypress, que implementa as seis primeiras camadas do modelo OSI do protocolo e permite que o usuário apenas (CHERMONT, 2007) se concentre no desenvolvimento da aplicação.

Da mesma forma, mas não tão popular, existe o L-Core, desenvolvido pela Loytec, que também contém toda a pilha LonTalk (LOYTEC, 2008) implementada, porém para microprocessadores com características físicas diferentes.

No entanto, como ambos utilizam o mesmo protocolo aberto, os dispositivos desenvolvidos com o NeuronChip, e os outros desenvolvidos com o LCores são interoperáveis.

Outra característica interessante desse protocolo é a política de acesso ao meio físico, que permite que toda a sua capacidade seja aproveitada.

O protocolo especifica uma forma de adaptação ao meio de transmissão (chamado de predictive p-persistent CSMA), com a finalidade de corrigir o seu tempo de acesso, levando em consideração a acomodação e propagação do sinal (CHERMONT, 2007).

Com isso, ele pode ser utilizado em diversos meios físicos e taxas de transmissão diferentes, como: par trançado (de 78 a 1250 kbps), rádio freqüência, infravermelho, fibra ótica (1250 kbps), cabo coaxial, rede elétrica, etc.

Já prevendo uma grande quantidade de dispositivos inteligentes, que poderiam estar presentes em uma planta, a forma de endereçamento do protocolo LonTalk foi desenvolvida com a finalidade de suportar uma grande quantidade de dispositivos. Pode-se ter até 32.385 dispositivos em um único domínio, sendo que até $2^{48}$ domínios diferentes são permitidos, o que resulta em

2 Os próximos itens que serão discutidos neste capítulo foram, em grande parte, retirados do databook da Motorola referente à tecnologia LonWorks ${ }^{\circledR}$, LonWorks ${ }^{\circledR}$ Tecnology Device Data, e de estudos realizados pela Conceito Tecnologia com o uso de equipamentos de análise de rede e de desenvolvimento de dispositivos. 
uma capacidade total de $2^{48} \times 32.385$ dispositivos em uma rede LonWorks $^{\circledR}$ (ECHELON CORPORATION, 1999).

\subsubsection{Endereçamento}

O protocolo LonTalk é bastante versátil no que diz respeito ao endereçamento de rede, uma vez que se pode adotar diversas formas de enviar uma mesma mensagem para um dispositivo.

Inicialmente, quando um dispositivo ainda não está configurado na rede de controle, pode-se utilizar o seu endereço físico, chamado de NeuronID.

Esse endereço é formado por 48 bits e é único por dispositivo. Ele é atribuído em fábrica, durante a produção do NeuronChip, L-Core ou qualquer que seja o microcontrolador que implemente o protocolo LonTalk.

Assim, quando o dispositivo ainda não possui um endereço lógico na rede, as mensagens são dirigidas a ele através de seu Neuron ID, contendo todos os 48 bits no campo destinatário da mensagem de rede.

Em uma rede LonWorks $^{\circledR}$ padrão, esse tipo de endereçamento somente é utilizado por ferramentas gerenciadoras, ou em um momento em que o dispositivo não se encontra comissionado (sem endereço de rede e definições de bindings).

Outra forma que se pode utilizar para endereçar um dispositivo na rede LonWorks ${ }^{\circledR}$ é através do seu domínio, subnet e nó.

O mais abrangente é o domínio, que pode ser formado por zero bytes, um byte, três bytes ou seis bytes, definido pelo desenvolvedor ou integrador da rede.

Cabe notar que aqui existe um limitante importante: um dispositivo de um determinado domínio não pode se comunicar direto com um dispositivo de um domínio diferente.

Isso não acontece na rede LonWorks ${ }^{\circledR}$, onde cada dispositivo pode fazer parte de dois domínios diferentes, permitindo que sejam realizadas funções de roteamento e, portanto, a interconexão entre domínios.

Cada domínio pode ter até 255 subnets, sendo que entre elas não existe a limitação de interações entre dispositivos. Por sua vez, cada subnet tem a 
capacidade de suportar até 127 nós.

Com essa estrutura de endereçamento, pode-se integrar até aproximadamente $2^{63}$ dispositivos de rede. A Figura 4 a seguir apresenta um diagrama hierárquico do endereçamento de rede:
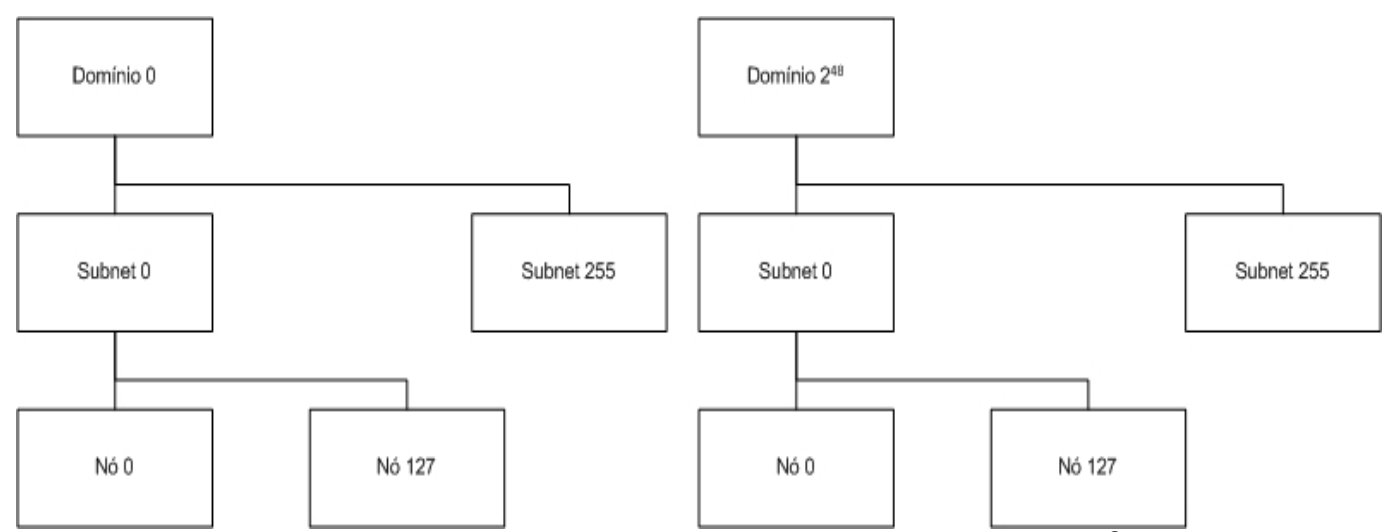

Figura 4 - Hierarquia de endereços na rede LonWorks ${ }^{\circledast}$

Como cada dispositivo de rede possui um endereço lógico único que não se repete em outros dispositivos, pode-se utilizá-lo para mandar uma mensagem diretamente para ele. Neste caso, ao invés de conter o Neuron ID no destinatário, terá o domínio, a subnet e o número do nó.

Este tipo de endereçamento é utilizado em qualquer momento em que o dispositivo já possua o endereço configurado, podendo ser tanto mensagens de aplicação como de gerenciamento de rede.

Considerando que os dispositivos já estejam com os seus endereços lógicos configurados, existem ainda algumas variações nas formas de endereçamento de mensagens.

Uma dessas variações é o broadcast, onde a subnet e o número do nó no campo destinatário não são definidos. Nesse tipo de endereçamento, uma determinada mensagem pode ser enviada a todos os dispositivos de rede de uma só vez, tornando uma possível atualização de variáveis ou requisição de determinado endereço, muito mais rápidos.

Outra variação é o multicast, sendo que este caso, pode ser realizado de diversas formas no protocolo LonTalk, quais sejam:

A primeira delas (e a mais simples), é o envio de uma mensagem de 
multicast para todos os dispositivos que pertençam à uma determinada subnet. Neste caso, o campo destinatário da mensagem deverá conter a especificação da subnet, sem a especificação do nó.

A segunda delas consiste em formar grupos de dispositivos, não importando se pertencem ou não, à mesma subnet. Em um domínio, podem ser formados até 255 grupos diferentes, e cada grupo pode conter até 64 nós, para o caso de mensagens de rede com reconhecimento (os tipos de mensagens serão discutidos no item seguinte).

Para o caso de mensagens de grupo, a estrutura do destinatário de uma mensagem é diferente e contém a informação do grupo ao qual ela se destina.

\subsubsection{Mensagens De Rede}

Outra característica do protocolo LonTalk é o tipo de mensagens e os serviços oferecidos. Primeiramente podem-se categorizar as mensagens em dois grandes grupos: as mensagens de aplicação e as mensagens de gerenciamento de rede.

As mensagens de aplicação são utilizadas pelos dispositivos para transmitir e receber informações entre si. Quando uma mensagem desse tipo é recebida, ela gera um evento na aplicação desenvolvida pelo usuário, implicando no tratamento de um dado ou qualquer atitude relacionada, conforme desenvolvido pelo fabricante do dispositivo. Importante se faz notar que este tipo de mensagem sempre implica em uma atitude na aplicação, mesmo que seja o descarte da informação recebida. Existem duas formas de se enviar mensagens de aplicação entre os dispositivos.

A primeira delas é a forma explícita, onde a aplicação determina diretamente o destinatário da mensagem (pode-se utilizar qualquer um dos métodos de envio citados anteriormente) e o seu formato (podendo conter até 255 bytes de comprimento, incluindo cabeçalho, dados etc). A desvantagem desse tipo de mensagem, diz respeito à redução da generalização da aplicação, pois os endereços dos destinatários já estão estabelecidos na programação e, portanto, perdendo-se o conceito de variável de rede.

A segunda, que é chamada troca de mensagens de forma implícita, 
permite que a aplicação seja totalmente desenvolvida, sem que o desenvolvedor conheça os dispositivos dos quais irá receber ou para os quais irá enviar. Basta ao desenvolvedor especificar os tipos de mensagens que serão transmitidas ou recebidas, desenvolvendo assim, a interface que o dispositivo irá possuir para poder se relacionar com outros e especificando as variáveis de rede que possui.

Essas mensagens já definidas são as chamadas variáveis de rede, em inglês, network variable (NV). Caso sua estrutura de dados obedeça ao padrão especificado pela LonMark, elas passam a ser chamadas variáveis de rede padrões, em inglês Standard Network Variable Type (SNVT).

Com a interface de todos os dispositivos da rede de controle, qualquer integrador poderá interligar as variáveis da forma como a aplicação atual necessitar.

A Figura 5 apresenta um exemplo de uma interface de rede definida para dois dispositivos:
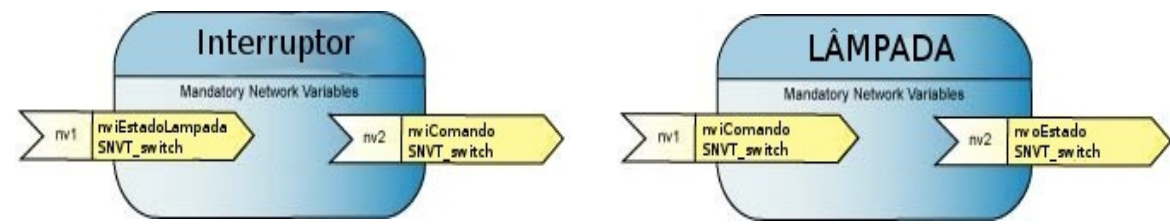

Figura 5 - Exemplo de interfaces de dispositivos de rede LonWorks ${ }^{\circledR}$

Como se pode observar, foi definida uma interface para um dispositivo lâmpada e outra para o dispositivo interruptor, de forma que ambos possuem uma snvt de saída e outra de entrada do tipo switch.

\subsubsection{Serviço De Entrega}

Agora que já foram apresentados os tipos de mensagens que podem ser enviadas pela rede, podem-se analisar a forma como elas são trocadas pelos dispositivos (os serviços de entrega disponíveis).

O protocolo LonTalk oferece quatro tipos diferentes de serviços de entrega, que podem ser selecionados durante o seu desenvolvimento ou configurados através de mensagens de gerenciamento de rede, utilizando-se de uma ferramenta de gerenciamento (caso o desenvolvedor tenha deixado essa opção disponível). 
- ACKD

Neste tipo de serviço, o receptor (ou receptores no caso de mensagens para grupos) deve enviar de volta para o emissor da mensagem, um reconhecimento que confirme o recebimento correto da mensagem. Caso o receptor não receba essa resposta, ele deverá retransmitir a mensagem conforme uma quantidade de vezes especificada, após um determinado timeout.

Caso a mensagem seja enviada para um grupo de dispositivos, o receptor deverá receber a mensagem de reconhecimento de cada integrante; caso contrário, ela será reenviada. Nesse caso, para evitar que o dispositivo receba mensagens duplicadas, existem identificadores de transações.

Cabe destacar que quando se utiliza variáveis de rede, todo o processo citado acima é realizado pela camada de rede, restando para a aplicação tratar apenas a informação recebida. Somente quando se trabalha com mensagens, todas as exceções de comunicação devem ser tratadas pela aplicação.

\section{- REQUEST}

Nas mensagens do tipo request, um determinado dispositivo faz uma requisição a um ou mais dispositivos, esperando pela resposta de cada um deles. A requisição recebida deverá ser tratada pela aplicação do dispositivo requisitado antes de qualquer resposta a ser enviada. Da mesma forma, a resposta recebida deverá ser tratada diretamente pela aplicação.

Especialmente nos casos em que se utiliza o NeuronChip, todas as mensagens de gerenciamento de dispositivos são tratadas pelo sistema operacional da Echelon, ficando invisíveis para a aplicação do usuário.

Da mesma forma que no serviço ackd, existem timeouts de envio e quantidade máxima de retransmissões, que podem ser configuradas durante a programação ou através de ferramentas de gerenciamento de rede.

\section{- UNACKD}

Este tipo de serviço faz com que uma mensagem seja enviada para um ou mais dispositivos e nenhuma resposta seja esperada. Por não esperar mensagens de confirmação, este serviço é muito utilizado quando se deseja passar 
informações para um grupo muito grande de dispositivos, evitando assim a sobrecarga da rede, durante o envio das respostas de confirmação de cada um deles (o que ocorreria no caso em que se utiliza o serviço ACKD).

\section{- UNACKD_RPT}

Funciona exatamente da mesma forma que o serviço anterior, com a exceção de que quando uma mensagem é enviada, ela é retransmitida uma determinada quantidade de vezes (configurável durante o desenvolvimento do dispositivo ou através de uma ferramenta de gerenciamento de rede). Através dessa repetição no envio da mensagem, diminui-se a probabilidade dela não ser recebida pelo dispositivo destinatário.

\subsubsection{Bindings}

O conceito de binding, utilizado na rede lonWorks ${ }^{\circledR}$, é importante para o entendimento de como um dispositivo pode se comunicar com outro através de mensagens implícitas, e utilizando o conceito de variáveis de rede.

Fazendo uma analogia com um circuito digital, realizar um binding entre dispositivos, é como ligar diretamente uma saída de um circuito integrado com uma ou mais entradas de outro. Ou seja, uma variável de saída pode ser ligada diretamente à uma variável de entrada, assim como uma variável de saída também pode ser conectada com diversas entradas e, por fim, duas ou mais variáveis de saída podem ser ligadas com uma ou mais variáveis de entrada.

Neste processo existe a limitação de se conectar apenas variáveis de saída dos dispositivos. Outra limitação, neste caso proposital, é que somente podem ser conectadas variáveis com a mesma estrutura de dados. Para viabilizar o processo de binding na tecnologia LonWorks ${ }^{\circledR}$, existem duas tabelas internas que precisam ser configuradas.

A primeira delas indica a configuração atual das variáveis de rede de um dispositivo, contendo informações como: a descrição da sua estrutura de dados; configurações de rede (como por exemplo, o serviço utilizado, se tem prioridade ou não, direção); etc.

Uma informação importante que essa tabela possui, é o seletor que 
a variável está utilizando no momento, pois ele define o binding entre as variáveis. Sua estrutura é:

struct \{

nv_struct nv_cnfg;

unsigned primary;

unsigned long host_primary;

\}alias_struct;

Essa tabela define o acesso à configuração de cada uma das variáveis de rede no dispositivo atual. A descrição mais detalhada da estrutura que contém toda a configuração de uma variável de rede é:

struct \{

$\begin{array}{lc}\text { unsigned nv_priority } & : 1 ; \\ \text { unsigned nv_direction } & : 1 ; \\ \text { unsigned nv_selector_hi } & : 6 ; \\ \text { unsigned nv_selector_lo } & : 8 ; \\ \text { unsigned nv_turnatound } & : 1 ; \\ \text { unsigned nv_service } & : 2 \text {; } \\ \text { unsigned nv_auth } & : 1 \text {; } \\ \text { unsigned nv_addr_index } & : 4 ;\end{array}$

\}nv_struct;

Essa tabela pode ser acessada tanto internamente, através de comandos de acesso à memória que retornam a estrutura descrita acima, quanto através da rede, com mensagens de gerenciamento. A seguir apresenta-se a descrição de cada campo:

- nv_priority

Esse bit é utilizado para indicar se determinada variável de rede possui ou não prioridade de acesso à rede. Ele pode ser configurado durante a programação do dispositivo ou através de ferramentas de gerenciamento de rede. Cabe notar ainda que esse campo é escrito quando a variável precisa ter prioridade ao acesso à rede. 
- nv_direction

Indica qual a direção da variável do dispositivo, utilizando o valor 1 (um) para saída e 0 (zero) para entrada. Esse bit é ajustado durante a programação do dispositivo e não pode ser alterado por ferramentas de gerenciamento.

- nv_selector_hi e nv_selector_lo

Esses quatorze bits formam o seletor da variável, sendo que os valores entre $0 \times 3000^{3}$ e $0 \times 3 F F F$ são reservados para variáveis que não estão conectadas (normalmente é atribuído o valor 0x3FFF menos o índice da variável).

Os valores entre 0 e 0x2FFF são utilizados para as variáveis que estão conectadas com outras. É importante notar que tanto para as variáveis de entradas quanto para as de saídas, o valor do seletor deve ser sempre diferente entre os dispositivos que se relacionam.

Por exemplo, se o dispositivo A possui um binding com o dispositivo $\mathrm{B}$, eles poderiam ter como seletor o número 1. Neste mesmo cenário, se um dispositivo $C$ se relacionar com o dispositivo $D$, eles poderiam também utilizar o seletor com o número 1.

No entanto, se o dispositivo A se relacionar com o C, por exemplo, o seletor 1 entre C e D não poderá mais ser aplicado, uma vez que ele já existe na relação $A$ e $B$.

- nv_turnatound

Quando este bit se encontra em 1 (um), indica que esta variável de rede está ligada à outra variável do próprio dispositivo físico.

- nv_service

Esse campo indica qual o tipo de serviço que a variável de rede está utilizando: ackd $=0$, unackd_rpt $=1$ e unackd $=2$.

- nv_auth

Este bit indica se a variável de rede utiliza transações com autenticação (quando um dispositivo necessita ser autenticado para que o outro

3 Os número precedidos por 0x tem seu valor na notação hexadecimal. 
possa receber a mensagem). Ele é configurado durante o desenvolvimento do dispositivo ou através de alguma ferramenta de gerenciamento de rede.

- nv_addr_index

Esse campo especifica o índice na tabela de endereço para esta variável de rede. Nos dispositivos NeuronChip, esse índice pode variar de 0 (zero) a 14 (catorze), sendo que 15 (quinze) é utilizado para variáveis que não estão associadas com nenhum índice.

Em um processo de binding, os campos nv_selector_hi, nv_selector_lo, nv_turnaround e nv_addr_index devem ser alterados conforme necessário para que o binding seja feito.

A segunda tabela, é chamada de Tabela de Endereços (address table). Essa tabela define todas as informações necessárias para o envio de mensagens implícitas, como destino, grupos, broadcasts etc. Sua estrutura é: union \{

group_struct gp;

snode_struct sn;

bcast_struct bc;

turnaround_struct ta;

\} address_struct;

Como se pode observar, essa tabela contém estruturas diferentes para cada tipo de endereçamento utilizado.

A primeira estrutura, contém informações específicas no caso de mensagens para grupos; já a segunda é utilizada no caso de mensagens diretas para um dispositivo utilizando o seu endereçamento lógico, a terceira é utilizada em broadcast de mensagem e a última estrutura no caso de mensagens de saída conectadas com o próprio dispositivo. A estrutura para mensagens de grupo é: struct \{

$\begin{array}{lll}\text { unsigned } & \text { type } & : 1 ; \\ \text { unsigned } & \text { size } & : 7 ; \\ \text { unsigned } & \text { domain } & : 1 ; \\ \text { unsigned } & \text { member } & : 7 ;\end{array}$




$\begin{array}{lll}\text { unsigned } & \text { rpt_timer } & : 4 ; \\ \text { unsigned } & \text { retry } & : 4 ; \\ \text { unsigned } & \text { rcv_timer } & : 4 ; \\ \text { unsigned } & \text { tx_timer } & : 4 ; \\ \text { unsigned } & \text { group } & : 8 ;\end{array}$

\} group_struct;

A estrutura para mensagens, utilizando a subrede e o número do nó de destino é:

struct \{

addr_type type;

unsigned domain $: 1$;

unsigned node :7;

unsigned rpt_timer :4;

unsigned retry :4;

unsigned rcv_timer :4;

unsigned tx_timer :4;

unsigned subnet :8;

\} snode_struct;

A descrição da estrutura para mensagens de broadcast é:

struct \{

addr_type type;

unsigned domain $: 1$;

unsigned $: 1$;

unsigned backlog :6;

unsigned rpt_timer $: 4$;

unsigned retry $: 4$;

unsigned $\quad: 4$;

unsigned tx_timer :4;

unsigned subnet :8;

\} bcast_struct;

A descrição da estrutura para mensagens de saídas que estão ligadas com variáveis do próprio dispositivo é: 
struct \{

$\begin{array}{lll}\text { addr_type } & \text { type; } & \\ \text { unsigned } & \text { turnaround; } \\ \text { unsigned } & \text { rpt_timer } & : 4 ; \\ \text { unsigned } & \text { retry } & : 4 ; \\ \text { unsigned } & & : 4 ; \\ \text { unsigned } & \text { tx_timer } & : 4 ;\end{array}$

\} turnaround_struct;

Existe também uma estrutura definida para mensagens que são endereçadas utilizando o Neuron ID de cada dispositivo, contudo esse tipo de endereçamento não é utilizado em mensagens implícitas, nem em variáveis de rede, portanto essa estrutura não entra na tabela de endereços.

A definição da estrutura de mensagens utilizando o neuron ID do destinatário é:

struct

\{

addr_type type;

unsigned domain :1;

unsigned :7;

unsigned rpt_timer :4;

unsigned retry $: 4$;

unsigned

unsigned tx_timer :4;

unsigned subnet 8

unsigned nid[NEURON_ID_LEN];

\} nrnid_struct;

Como se pode observar, todas as estruturas possuem os campos necessários para que o destino seja atingido, além disso, também contêm algumas informações relacionadas à transmissão da informação, como tempo de repetição, número de repetições, etc.

A seguir apresenta-se uma descrição de cada campo seprarademente. 
- unsinged type

Este bit estará em estado lógico 1 (um) caso seja endereçamento de grupo e 0 (zero) para os demais casos.

- addr_type type

Indica o tipo de endereçamento conforme a estrutura s seguir:

enum

\{

UNBOUND,

SUBNET_NODE,

NEURON_ID,

BROADCAST

\} addr_type;

Unbound indica que esta entrada da tabela não está ligada a nenhum outro dispositivo.

- Subnet_node indica que o endereçamento utiliza a subrede e o número do Nó.

- Neuron_id indica que o endereçamento será realizado através do neuron Id do dispositivo de destino;

- Broadcast indica que é uma mensagem para todos os dispositivos da rede.

- size

Este campo serve para indicar o tamanho do grupo para o qual a mensagem se destina (incluindo o nó de origem). Seu valor varia de 2 a 64 dispositivos.

Caso esteja se utilizando mensagens que com o serviço unackd ou unackd_rpt, pode-se formar grupo de tamanho ilimitado. Neste caso o valor de size será 0 .

- domain

Este bit irá indicar qual o índice da tabela (zero ou um) será utilizado para o envio da mensagem. Esse indicador se faz necessário uma vez que, como 
citado anteriormente, cada nó de rede pode fazer parte de dois domínios diferentes. No caso do NeuronChip, o índice zero da tabela contém as informações de configuração para um dos domínios e o índice um para o outro.

- member

Este campo irá indicar qual o identificador do nó dentro do grupo formado. Assim, no caso de mensagens que necessitem de reconhecimento (ACKD), o emissor pode saber quais e quantos deles ainda não reconheceram a mensagem. Cabe notar que no caso de grupos de tamanho ilimitado, este campo será sempre zero.

- node

Este campo especifica o número do nó de destino dentro da subrede e domínio para o qual a mensagem será enviada. O número varia de 1 (um) a 127 (cento e vinte e sete), sendo 0 (zero) um valor inválido.

- subnet

Especifica o número da subrede de 1 (um) a 255 (duzentos e cinquenta e cinco) para a qual a mensagem será enviada. No caso de mensagens de broadcast, esse valor especifica, na verdade, um multicast para todos os dispositivos de determinada subrede. Em mensagens que utilizem a forma de endereço subrede/nó, o valor zero é inválido, já no caso de mensagens de broadcast, o valor zero indica que todas as subredes deverão receber. Por fim, em mensagens que serão enviadas utilizando o neuron id do destinatário, a subrede é somente utilizada para efeito de roteamento. Caso se necessite que todos os roteadores a repliquem, basta utilizar 0 (zero) no seu valor.

- backlog

Este valor é uma estimativa de ocupação do canal, baseado na quantidade de dispositivos que devem responder a uma mensagem do tipo ackd ou request. Caso não se tenha essa estimativa, deve-se carregar esse campo com 0 (zero). 
- turnaround

Este flag indica que a mensagem deve ser enviada para o próprio dispositivo. Se ele for carregado com o valor 0 (zero), significa que esta entrada da tabela não está sendo utilizada.

- rpt_timer

Especifica, conforme uma tabela, o tempo entre repetições de mensagens que utilizem o serviço unackd_rpt.

- retry

Especifica a quantidade de vezes que uma mensagem será repetida, como no caso de mensagens que necessitem de reconhecimento ou que utilizem o serviço unackd_rpt.

- rcv_timer

Esse campo especifica o tempo que um dispositivo deve esperar para considerar novas mensagens com o mesmo identificador de transações. No caso de uma mensagem de grupo, por exemplo, esse valor é importante, pois caso o dispositivo receba duas mensagens com o intervalo de tempo entre elas menor do que o especificado neste campo e com o mesmo identificador de transações, a segunda será descartada.

- tx_timer

Esse campo especifica o tempo mínimo entre duas mensagens que necessitam de resposta, como o caso daquelas que utilizam o serviço ACKD ou REQUEST. Esse tempo de espera é importante para que o dispositivo destinatário tenha tempo suficiente para processar a mensagem.

Diferentemente da tabela anterior, onde somente alguns valores eram modificados, a tabela de endereço deve ser totalmente configurada. Note que como citado anteriormente, no caso em que se utilizou o NeuronChip, tem-se apenas 15 possibilidades diferentes de configuração (de 0 a 14). No entanto, essa limitação deve-se apenas à limitação de hardware (neste caso memória), no caso do 
L-Core por exemplo, essa limitação é diferente.

\subsubsection{Exemplo de Binding}

Para demonstrar o funcionamento do binding na tecnologia LonWorks $^{\circledR}$, podem ser utilizados dois dispositivos: o dispositivo lâmpada e o dispositivo interruptor. O dispositivo lâmpada têm duas variáveis de rede:

A primeira delas, é uma variável de entrada e é do tipo padrão switch, portanto, tem-se uma entrada SNVT, chamada comando, do tipo switch. Essa variável é responsável por comandar o estado do dispositivo, acendendo ou apagando a lâmpada.

A segunda variável é uma saída, e do mesmo tipo padrão que a entrada, ou seja, switch. Por sua vez, essa variável serve para indicar qual o estado atual em que o dispositivo se encontra, mostrando se a lâmpada está acesa ou apagada.

Com essas duas variáveis de redes, pode-se montar a interface que o dispositivo apresenta para ser integrada com outros dispositivos da rede LonWorks $^{\circledR}$. A Figura 6 apresenta a interface do dispositivo lâmpada na ferramenta de gerenciamento de rede LonMaker:

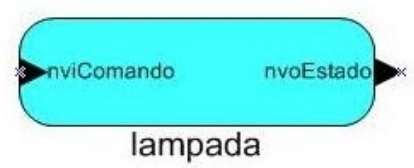

Figura 6 - Interface lógica da lâmpada no LonMaker

Da mesma forma que o dispositivo lâmpada, o interruptor possui duas variáveis de rede padrão do tipo switch. A variável de entrada serve para que ele seja informado em que estado se encontra a lâmpada, dessa maneira, ao ser acionado ele sabe se deve mandar a lâmpada acender ou apagar. Essa característica é importante para permitir que muitos interruptores controlem uma ou 
mais lâmpadas; e sem essa informação o interruptor poderá enviar o comando incorreto ou não enviar nada.

A variável de saída serve para que ele envie o comando para a lâmpada acender ou apagar baseado em seu estado atual, conhecido através da variável de entrada. A Figura 7 apresenta a interface de rede do dispositivo interruptor, também no LonMaker:

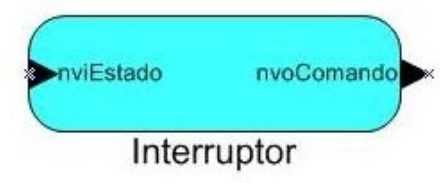

Figura 7 - Interface lógica do interruptor no LonMaker

Com os dois dispositivos definidos e já instalados corretamente em uma rede de controle LonWorks ${ }^{\circledR}$, agora pode-se interligá-los logicamente de forma que eles possam interagir, fazendo com que o interruptor controle a lâmpada.

Atualmente, para que isso seja feito, é necessário utilizar a ferramenta de gerenciamento de rede LonWorks ${ }^{\circledR}$, pois ela permite que os dispositivos sejam configurados e posteriormente suas variáveis de rede interconectadas de forma que eles passem a interagir.

Utilizando o LonMaker (desenvolvido pela Echelon) como a ferramenta de gerenciamento de rede, primeiramente monta-se a estrutura da rede utilizando uma representação dos dispositivos físicos.

A Figura 8 apresenta a estrutura montada da rede e a representação dos dispositivos. Note que a cor dos dispositivos para a dada representação mostra que esses ainda não foram configurados e portanto, ainda não se encontram em funcionamento ou comissionados: 


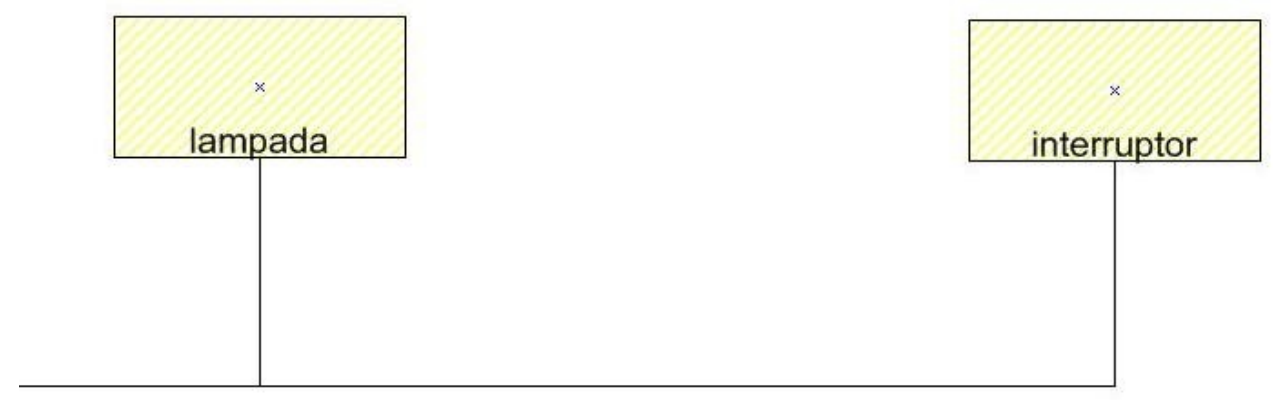

Figura 8 - Representação de dispositivos descomissionados

$\mathrm{O}$ ato de comissionar os dispositivos, representa a ação de realizar todas as suas configurações lógicas na rede de controle que o permitam estar inserido no ambiente, podendo se comunicar com os demais dispositivos, o que significa dizer que um nó está comissionado se ele possui um endereço válido e as configurações de bindings.

Além da representação física do dispositivos, o LonMaker permite que suas interfaces, também chamadas de perfis funcionais, sejam visualizadas separadamente conforme definidas anteriormente, durante 0 período de desenvolvimento do dispositivo. A Figura 9 apresenta os dispositivos e suas respectivas interfaces lógicas, ou os perfis funcionais:
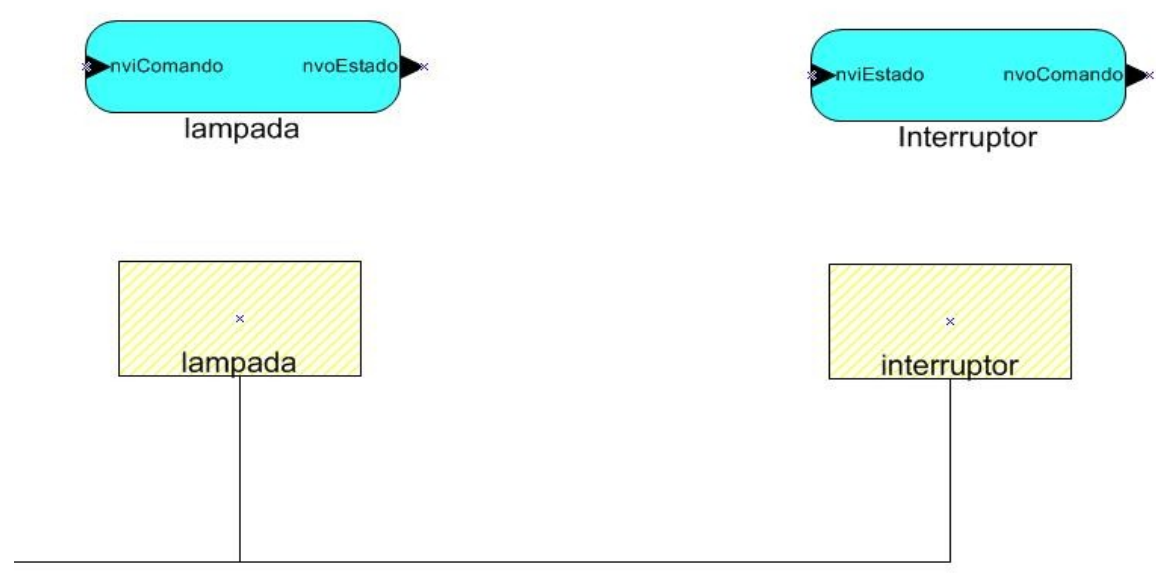

Figura 9 - Dispositivos e seus respectivos blocos funcionais

Utilizando os perfis funcionais, pode-se então interligar as variáveis 
de rede, formando as interligações lógicas entre os dispositivos da rede e definindo como será a comunicação entre eles. Primeiramente, para facilitar o entendimento de como o bind é realizado, será ligado apenas à variável de saída da lâmpada com a variável de entrada do interruptor. Nesse exemplo em específico, essa ligação é realizada primeiro para que o interruptor conheça o estado atual da lâmpada, necessário para saber que comando será enviado após a atuação do usuário:
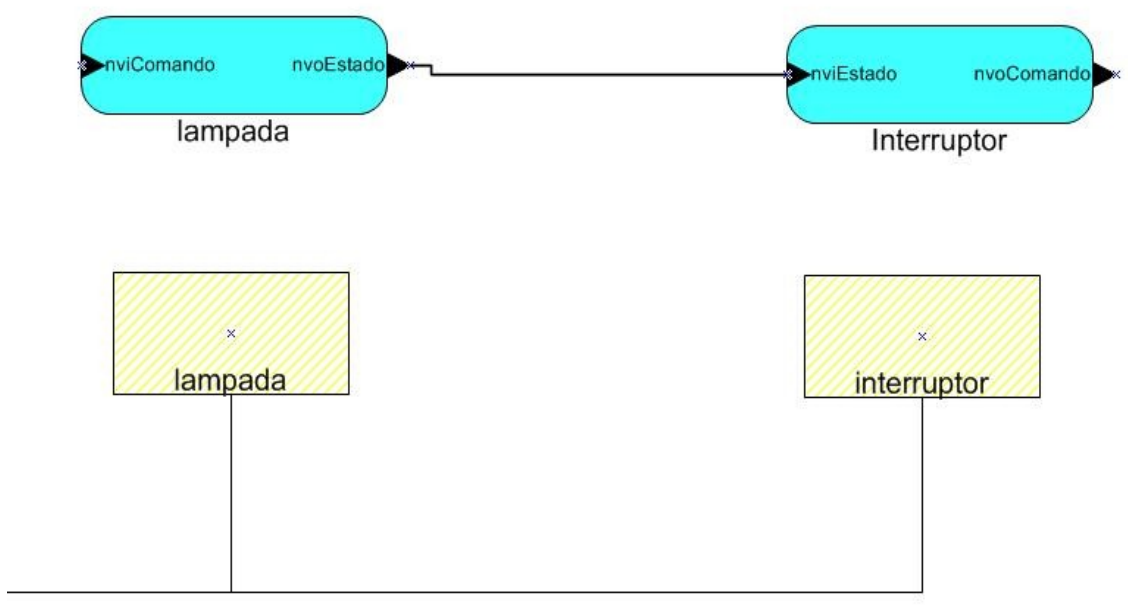

Figura 10 - Representação do binding entre a lâmpada e o interruptor

Até o momento, todas as ações que foram realizadas na ferramenta de gerenciamento não foram aplicadas nos dispositivos reais, somente nos bancos de dados, uma vez que eles se encontram descomissionados. Portanto, para que o bind seja aplicado, é necessário comissionar os dispositivos, nesse caso, copiar as informações de configuração e de bindings para a memória interna do nó.

Após esse passo, através do uso de mensagens explícitas endereçadas para o endereço físico, é passado ao nó o seu endereço lógico e informações dos bindings. Em alguns casos, também pode ser passado toda a aplicação que será executada.

A seguir a representação dos dispositivos comissionados, o que significa que o LonMaker configurou em seus dispositivos físicos suas tabelas de endereços e de bindings. Nesse estado, representado pela cor verde, eles se encontram em funcionamento na rede de controle, comunicando entre si: 

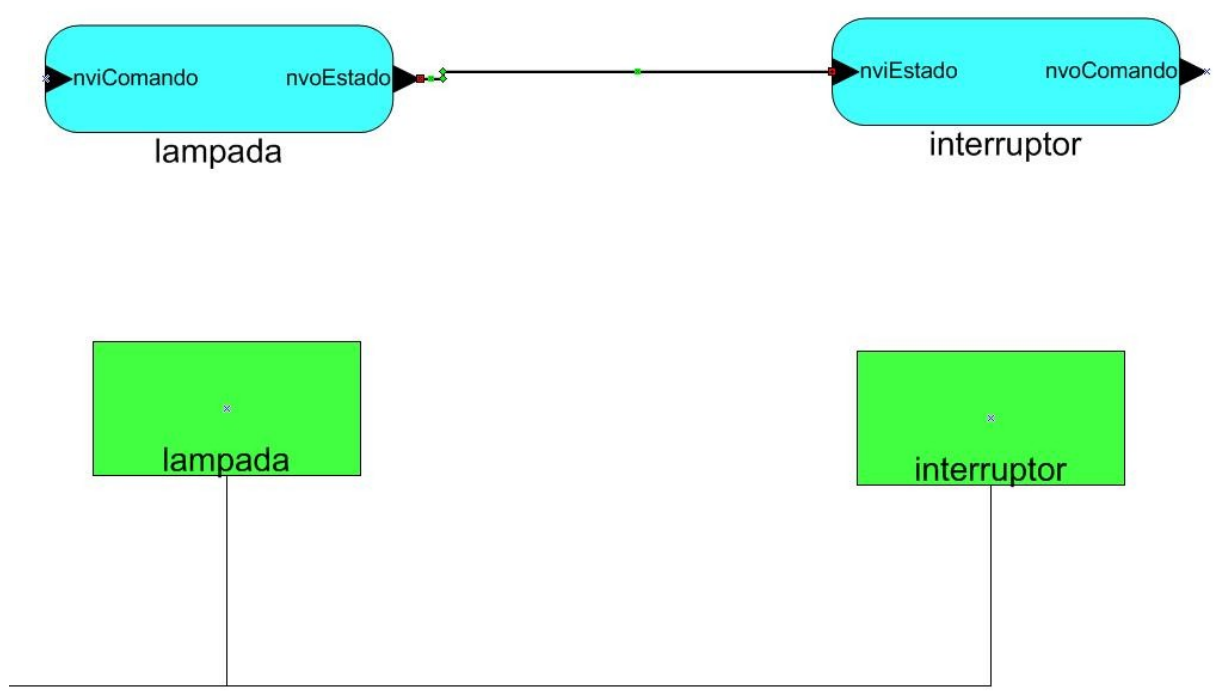

Figura 11 - Dispositivos comissionados pelo LonMaker

Agora, utilizando o LonMaker, é possível analisar as tabelas e suas respectivas estruturas de dados, conforme citado anteriormente, e verificar como elas estão configuradas.

Nesse caso em específico, o endereço dado ao dispositivo lâmpada, foi o nó número 2, subrede 1 domínio 9 e ao dispositivo interruptor foi o nó número 4, subrede 1 e domínio 9. Como se utilizou o LonMaker, devido a características da ferramenta, tanto o nó quanto a subrede não podem ser definidos ou modificados pelo usuário, ele somente permite definir o domínio da rede. A Figura 12 é a cópia da tabela de endereços da lâmpada:

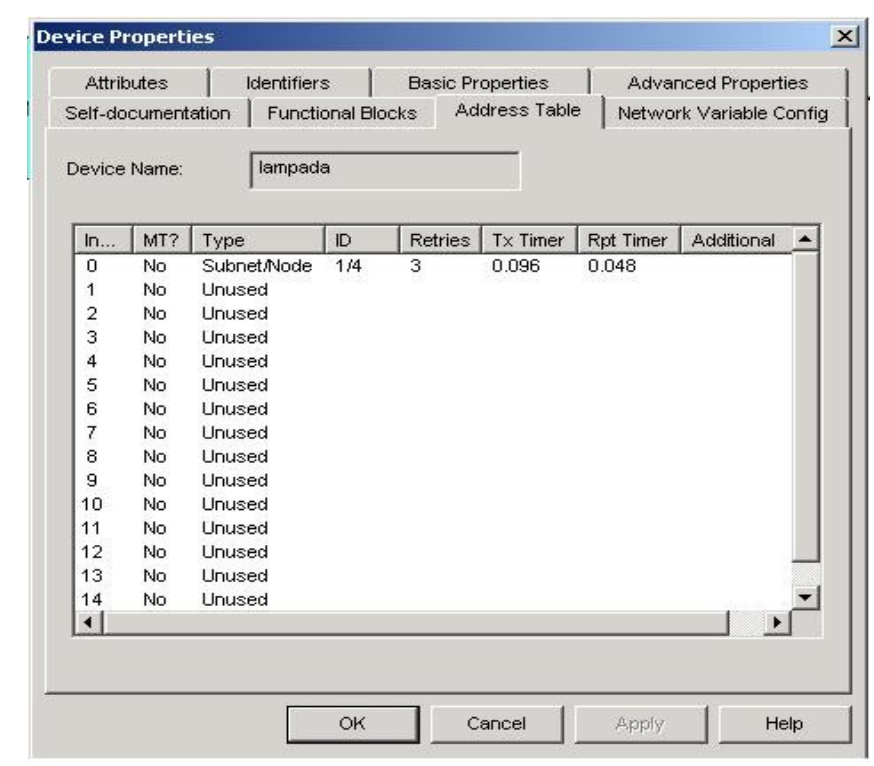

Figura 12 - Tabela de endereços da lâmpada comissionada 
Como se pode observar na Tabela de Endereços da lâmpada, foi adicionado ao índice 0 (zero), o tipo de endereçamento utilizado para o envio dessa mensagem (nesse caso subnet/node), o endereço lógico do nó de destino, ou seja, o interruptor (subrede 1, nó número 4). Depois seguem algumas configurações de comunicação como a quantidade máxima de retransmissões, tempo entre transmissões e tempo de repetição. Na Figura 13 se verifica uma cópia da Tabela de Configuração de Variáveis da lâmpada.

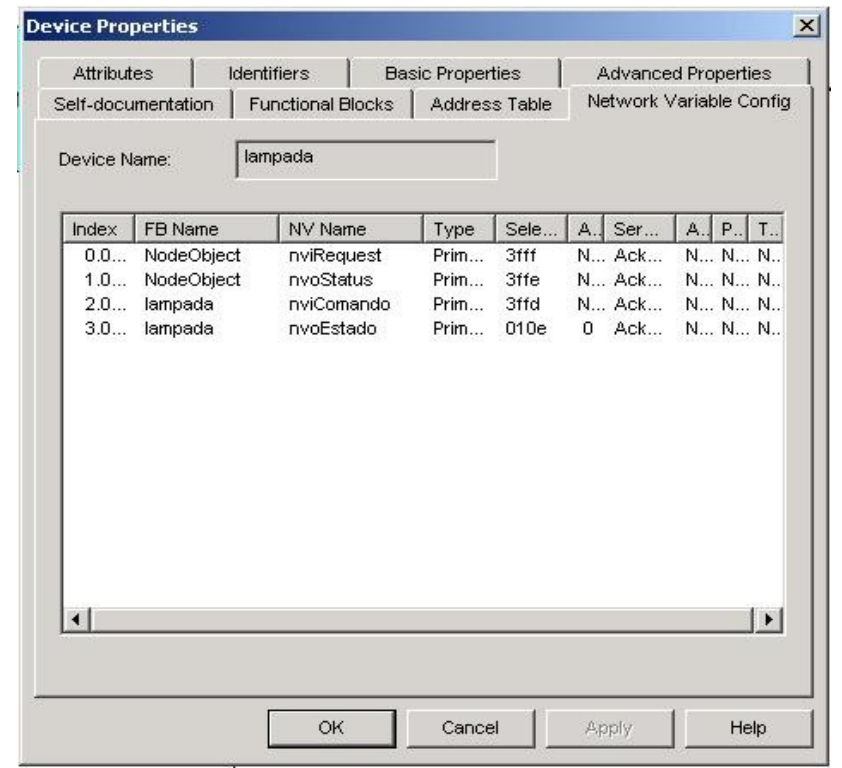

Figura 13 - Tabela de configuração de variáveis da lâmpada

Essa tabela, conforme especificada anteriormente, contém informações a respeito da variável e de como ela será utilizada na rede. Aqui podese ver o índice de cada variável, em seguida o nome do bloco funcional ao qual pertence, o nome da variável, seu tipo, seletor, endereço, serviço utilizado e alguns flags, como autenticação, prioridade e se é loopback.

Verifica-se no exemplo que foi conectada apenas a variável nvoEstado da lâmpada com a nviEstado do interruptor, e este fato pode ser confirmado observando-se o seletor dessa variável nvoEstado na Figura 13 acima (0x010E).

Não se tem informação a respeito de como o LonMaker define o número do seletor utilizado, no entanto, pode-se observar que ele atende à 
especificação do protocolo, onde está definido que deve ser utilizado um número a seguir de 0x2FFF.

Ainda na Figura 13, observa-se o seletor das demais variáveis, que não foram conectadas. Nestes casos, ele é formado pelo número 0x3FFF diminuído pelo índice da respectiva variável.

De forma análoga à lâmpada, a Figura 14 apresenta as tabelas do interruptor.
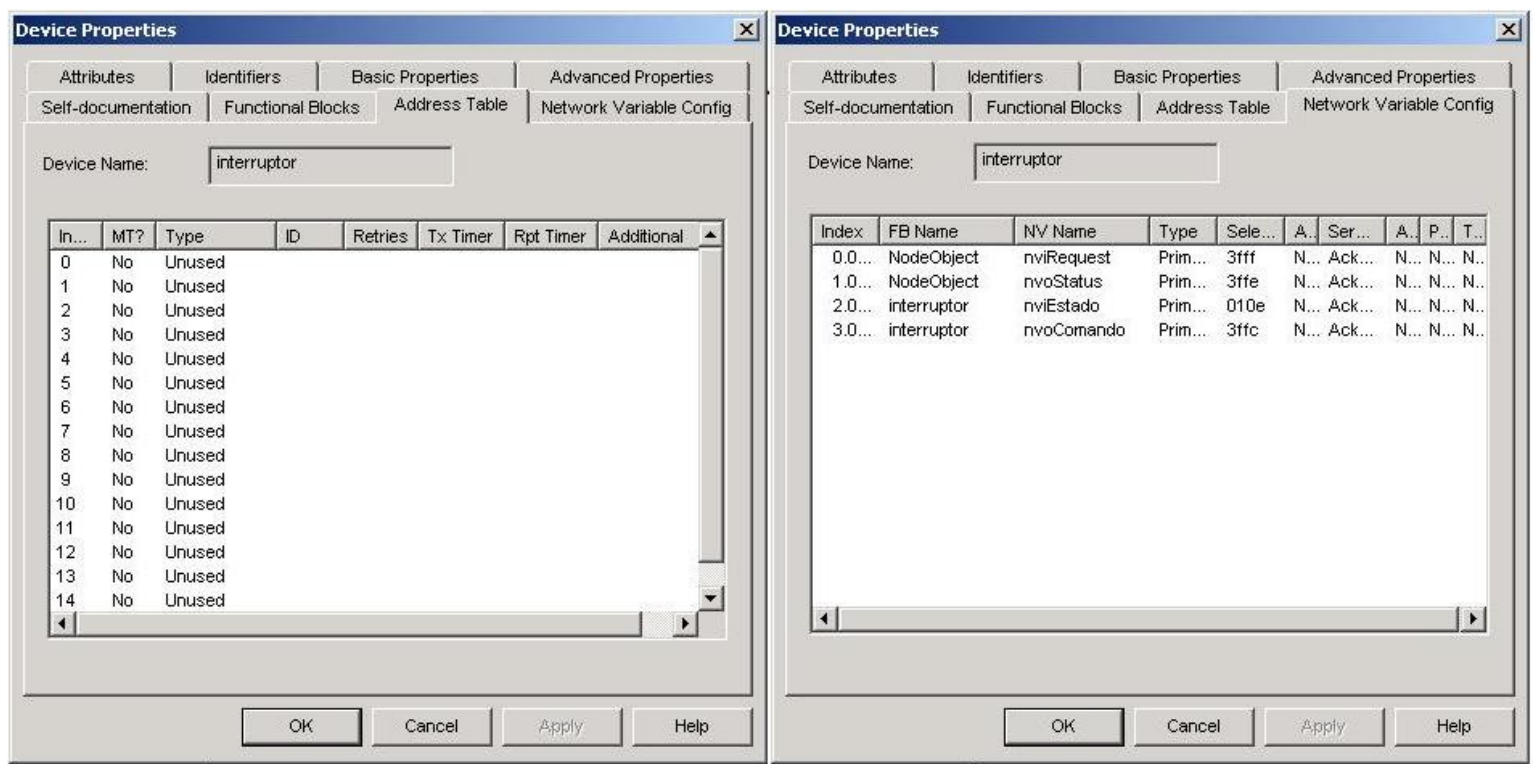

Figura 14 - Tabela de endereços e de variáveis do interruptor

No caso da tabela de endereços, diferentemente da lâmpada, o interruptor não necessita de nenhuma informação, uma vez que deve apenas responder com o reconhecimento da mensagem da lâmpada. Como na própria mensagem enviada pela lâmpada há o endereço do destinatário e o tipo de serviço utilizado (neste caso ackd), o interruptor utiliza estas informações para responder.

A única necessidade para que o interruptor saiba que irá receber uma mensagem, é o seletor. Como se pode observar na Tabela de Configuração de Variáveis de Rede, o seletor presente na variável nviEstado do interruptor (índice 2) é o mesmo presente na variável nvoEstado da lâmpada, 0x010E.

Continuando com o estudo das tabelas de bindings, agora pode-se conectar a variável nvoComando do interruptor com a variável nviComando da lâmpada. A Figura 15 apresenta a imagem dos bindings entre o interruptor e a lâmpada: 

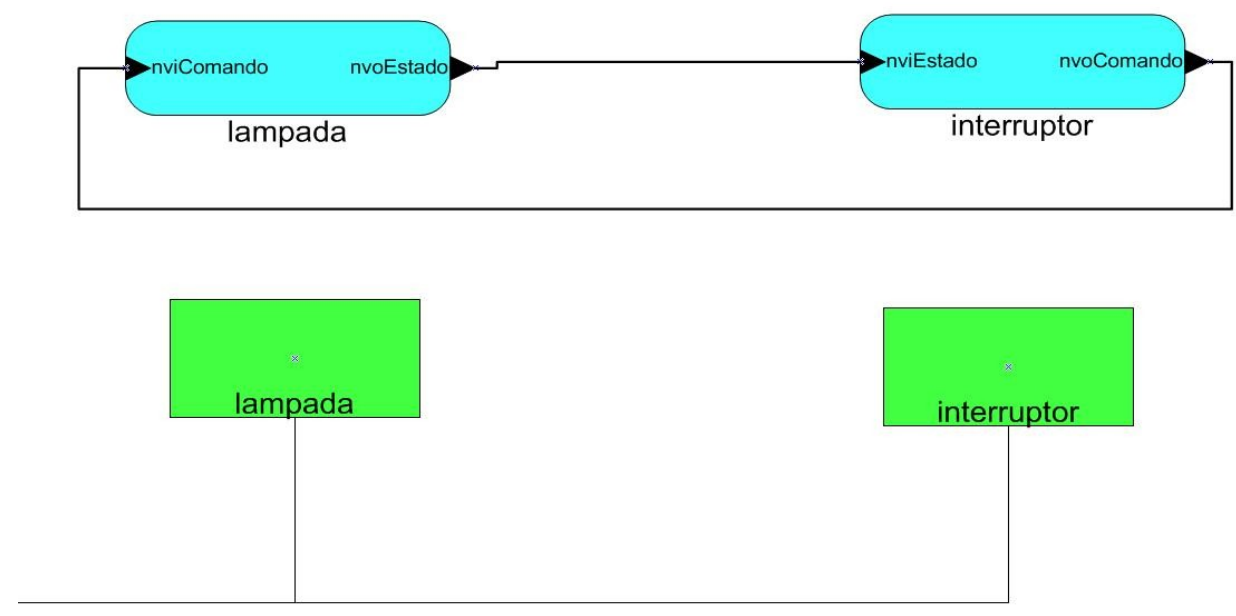

Figura 15 - Bindings entre interruptor e lâmpada

Com esse binding realizado, o interruptor passa a comandar o estado da lâmpada, enviando-Ihe mensagens através da rede de controle.

A Figura 16 apresenta as tabelas dos dois dispositivos após a realização do binding entre nvoComando e nviComando:
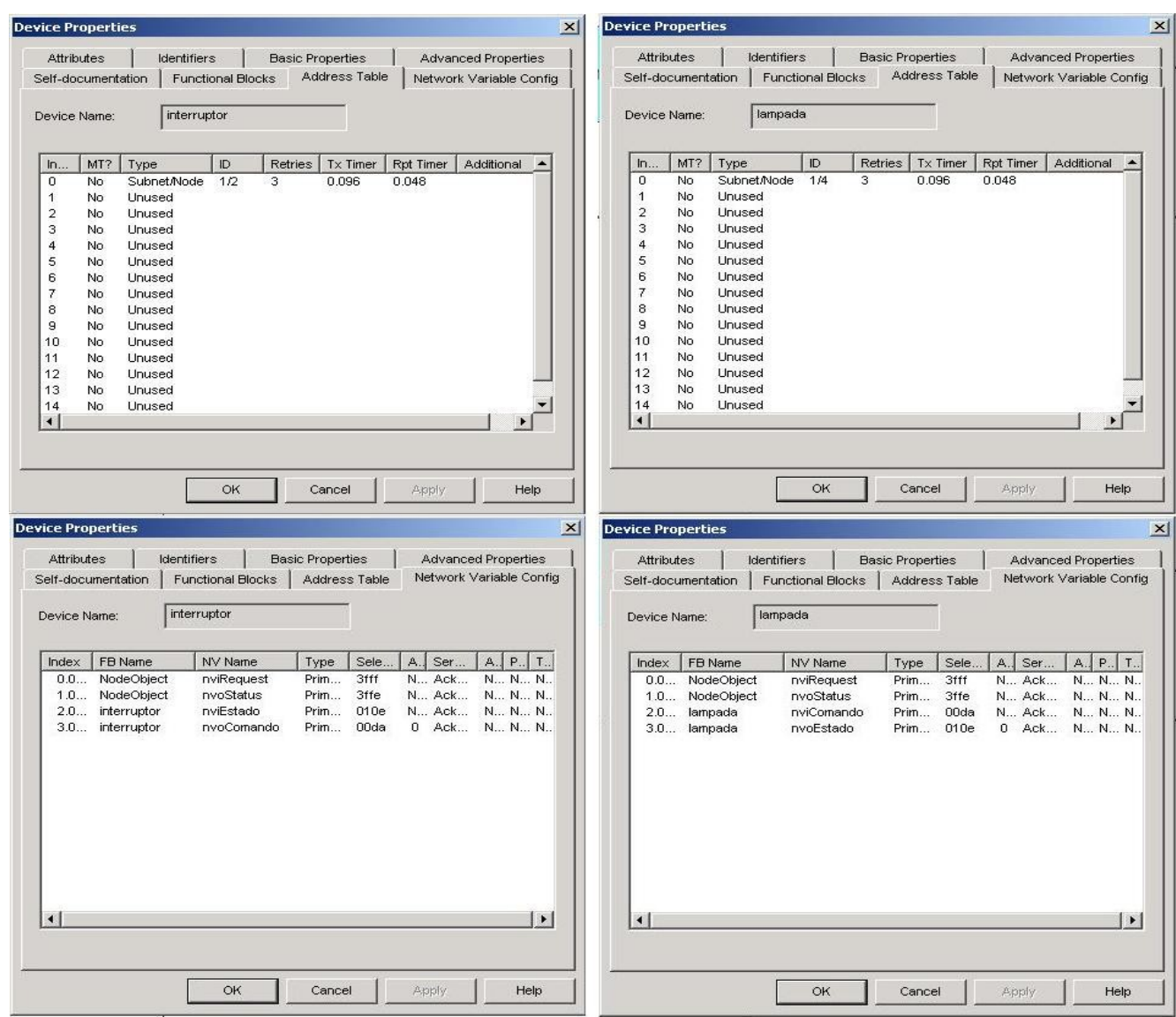

Figura 16 - Tabelas internas do interruptor e da lâmpada

Com essa nova configuração de bindings, pode-se observar que as 
tabelas dos dispositivos foram alteradas. À Tabela de Endereços do interruptor, que antes estava vazia, foi adicionado um novo endereço, subrede 1 (um) nó 2 (dois), que corresponde à lâmpada, configurando o dispositivo destinatário da mensagem nvoComando. Ao mesmo tempo, observa-se que a tabela de endereços do dispositivo lâmpada não foi alterada, uma vez que o endereço de resposta de reconhecimento de mensagens nvoComando, encontra-se na própria mensagem ao ser enviada.

No caso das tabelas de configuração de variáveis de rede, em ambos os dispositivos foi adicionado um novo seletor 0x00DA. Este seletor identifica que a variável nviComando da lâmpada deve receber mensagens nvoComando do interruptor.

Como se pôde observar, ao realizar um binding na tecnologia LonWorks $^{\circledast}$, na verdade deve-se configurar estas duas tabelas conforme definido na norma, permitindo que os dispositivos se comuniquem com aqueles que a aplicação necessita.

E para garantir que um dispositivo possa ser utilizado em qualquer aplicação e com qualquer configuração, foram desenvolvidos métodos de configuração através de mensagens de gerenciamento de rede. Isso permite que o dispositivo seja desenvolvido e depois configurado em uma rede de controle.

Ocorre um problema na documentação desses processos: uma vez que no databook da tecnologia não há um procedimento padrão estabelecido, e as ferramentas de configuração são proprietárias, os processos utilizados não são divulgados de forma aberta.

\subsection{NEURON CHIP}

Como base principal da tecnologia LonWorks ${ }^{\circledR}$, está o NeuronChip. Ele é a base da grande maioria dos produtos LonWorks ${ }^{\circledR}$, e possui características singulares, que o torna um grande atrativo para os desenvolvedores de produtos e sistemas de automação.

Esse chip foi desenvolvido pela Motorolla em parceria com a Echelon, com a finalidade de obter um microcontrolador barato e de fácil uso para desenvolvimento de novas aplicações, além de tornar toda a camada de 
comunicação de rede invisível para o desenvolvedor.

É uma combinação de hardware e firmware que provê todas as principais funções necessárias para o tratamento de entradas e o fornecimento de saídas para sensores e atuadores, além de fornecer também um complexo e eficiente sistema de comunicação permitindo o seu uso em diversos meios físicos diferentes sem afetar a aplicação, no que diz respeito à sua codificação.

Atualmente existem duas famílias diferentes de NeuronChips, a primeira chamada de 3150 e a segunda de 3120. A diferença entre elas está nas suas características físicas, como quantidade de memória, processamento, entradas e saídas etc. O NeuronChip, na verdade, é formado por três microprocessadores que trabalham em conjunto. Apesar dessas diferenças a estrutura básica de processamento é a mesmas para ambos os casos.

A Figura 17 apresenta o desenho esquemático do núcleo do NeuronChip:

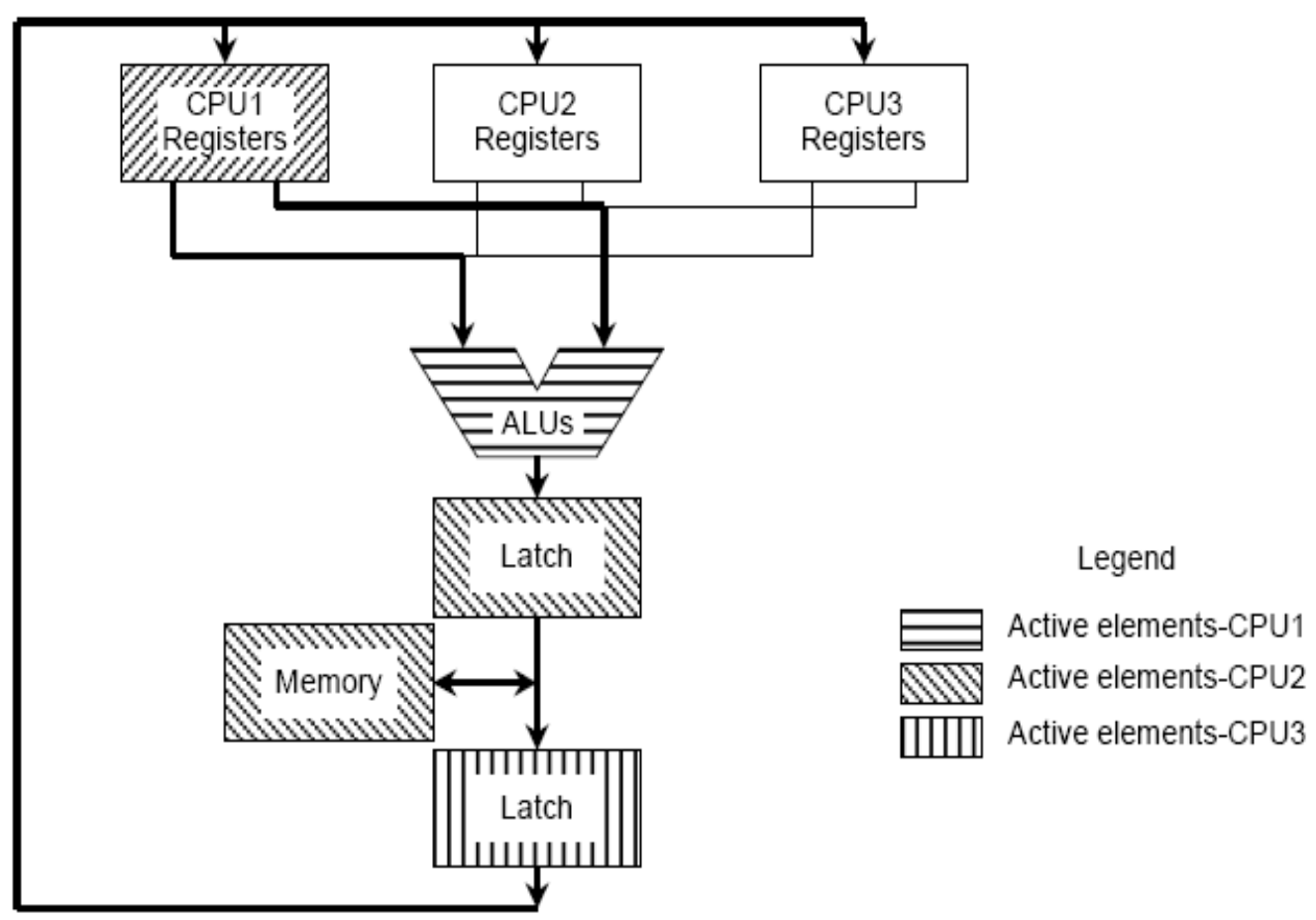

Figura 17 - Estrutura de processamento do NeuronChip (ESTADOS UNIDOS, 1997)

Como se observa na Figura 17, os três microprocessadores possuem registradores individuais e a comunicação entre eles ocorre através de 
memórias compartilhadas. Cada uma dessas unidades centrais de processamento, em inglês central processing unities (CPUs), possui funções independentes:

A primeira CPU realiza o acesso ao meio de comunicação, trata as camadas um e dois do protocolo LonTalk e lida diretamente com o driver de acesso ao meio, também chamado de transciever. Realiza também todas as funções de camada dois, como o tratamento de colisões, erros etc.

A segunda CPU, também chamada de processador de rede, realiza todas as funções que vão da camada três à seis do protocolo LonTalk, lidando com funções de processamento de variáveis, roteamento de mensagens, endereçamento e todas as demais funções englobadas por essas camadas.

Por fim, a terceira CPU realiza a camada de aplicação, número sete. Ela é responsável por executar o programa desenvolvido pelo usuário, além de todas as funções de sistema operacional chamadas pelo desenvolvedor durante a execução do código.

Como existem esses três processadores separados, o usuário ganha um grande desempenho nas suas aplicações, uma vez que tem uma CPU totalmente disponível, pois, todo o restante de serviços, como a troca de mensagens, é realizado por outros dois processadores em paralelo.

Do ponto de vista do desenvolvimento de aplicações, a existência dessa complexa arquitetura não aumentou a sua dificuldade ou a complexidade do código, uma vez que o usuário não tem acesso direto aos processadores, com exceção do terceiro (referente à camada de aplicação), e o tratamento das variáveis de rede funciona como acesso às variáveis de programação, porém com uma estrutura de dados pré-definida.

Para que os processadores possam trocar informações entre eles, são compartilhadas memórias específicas de acordo com a sua função. A Figura 18 demonstra como é realizado esse compartilhamento: 


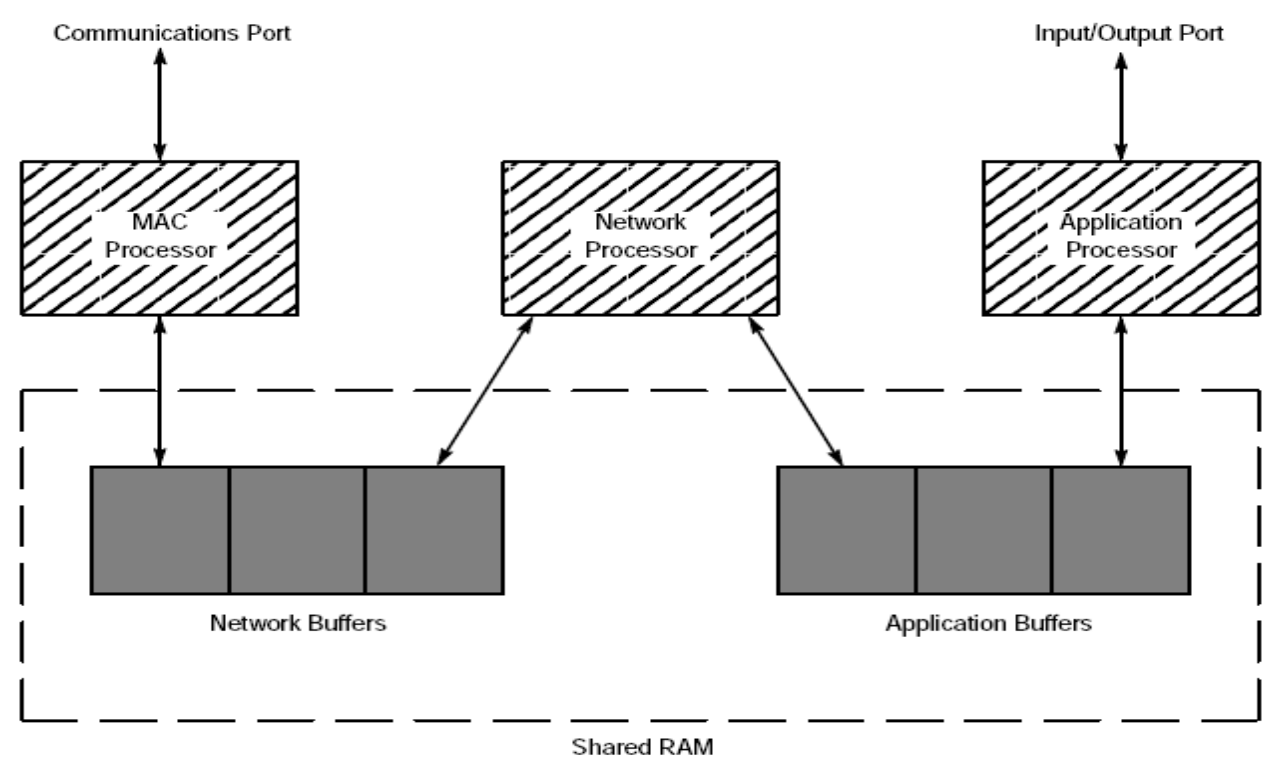

Figura 18 - Memórias compartilhadas pelos processadores (ESTADOS UNIDOS, 1997)

Como demonstra a Figura 18 acima, entre o processador MAC e o processador de rede existe um buffer de rede, e é através dele que a informação é tratada entre esses dois processadores. Já entre o processador de rede e o processador de aplicação existe o buffer de aplicação, e é através dele que é realizada a troca de informações entre esses dois processadores.

Além dessas memórias compartilhadas para a troca de mensagens, todo NeuronChip tem uma memória electrically-erasable programable read only memory (EEPROM) interna contendo todas as informações de configuração e endereçamento, o neurolD do dispositivo e de forma opcional, dependendo da família utilizada e da configuração de memória utilizada, o sistema operacional e aplicação do usuário. No caso específico do 3150, pode-se utilizar um EEPROM externa para armazenamento do sistema operacional e da aplicação do usuário.

Além disso, o NeuroChip tem uma característica importante a respeito dos dados contidos na EEPROM. Para evitar que uma aplicação corrompida ou endereçamento acidentalmente trocado seja utilizado, existe um checksum de todos os seus dados. Existem três checksums diferentes: checksum da configuração, checksum da aplicação e checksum do sistema operacional.

Toda vez que o NeuronChip é inicializado, ele executa a verificação de todos os checksums em relação aos seus respectivos dados contidos. Caso seja 
detectado alguma alteração acidental em qualquer um dos casos, o NeuronChip não entra em operação.

Da mesma forma que exite a memória EEPROM, o NeuronChip contém memória RAM interna. Ela é utilizada para variáveis da aplicação, pilha, dados do sistema etc.

A Figura 19 a seguir contém possíveis mapeamentos de memórias que podem ser utilizados:
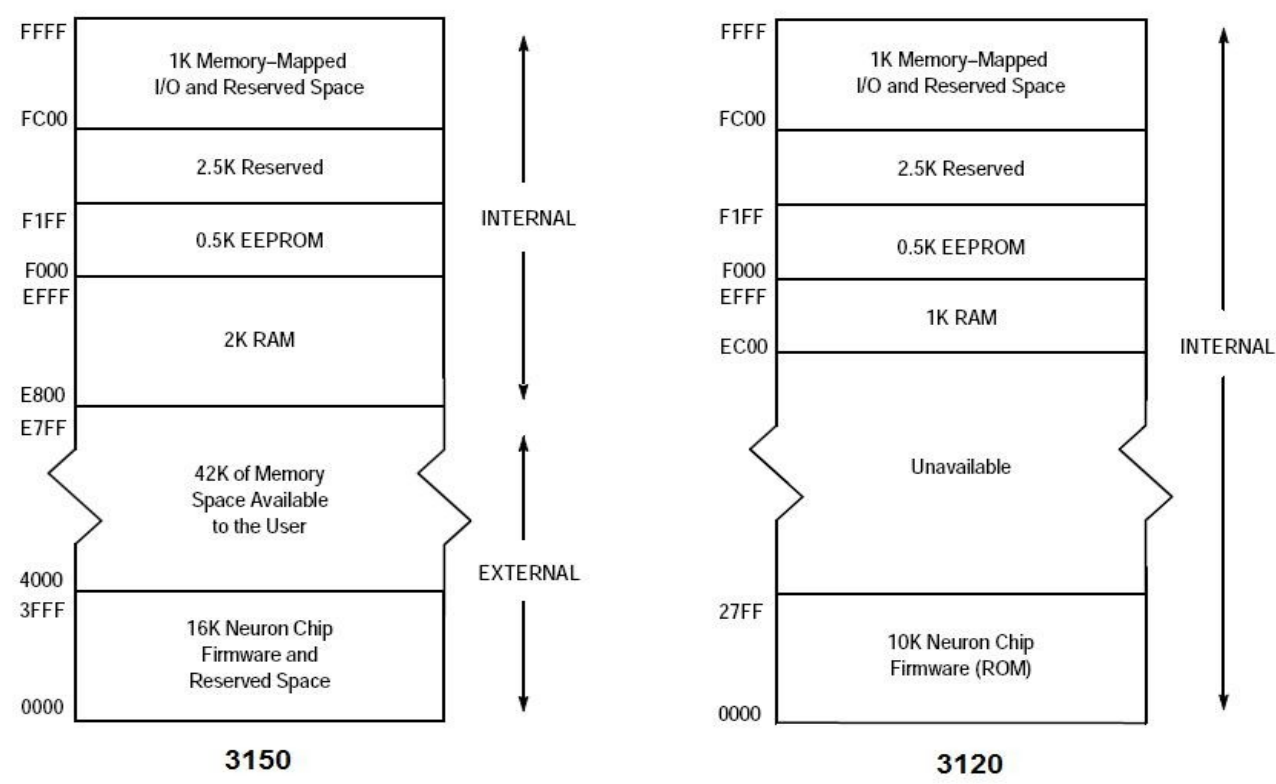

Figura 19 - Exemplo de mapas de memória (ESTADOS UNIDOS, 1997)

O NeuronChip também possui onze portas bidirecionais, que podem ser configuradas como entradas ou saídas e ter sua direção alterada em tempo de execução.

Utilizando as funções fornecidas pela Echelon no sistema operacional do NeuronChip, essas portas podem ser configuradas para trabalhar de diversas formas diferentes, como para executar comunicação paralela, serial, SPI etc, ou para funcionarem como contadores ou geradores de pulso, leitor de encoders etc.

Para finalizar, o NeuronChip possui timers internos de 16 bits que podem ser configurados para trabalhar de diversas formas diferentes, como contadores de tempo para identificar freqüências, geradores de pulsos, etc. 


\subsubsection{Exemplo de Utilização}

Para exemplificar como pode ser utilizado o NeuronChip, serão utilizados os exemplos citados anteriormente (a lâmpada e o interruptor). A Figura 20 apresenta o desenho esquemático de como a lâmpada pode ser montada utilizando-se o NeuronChip:

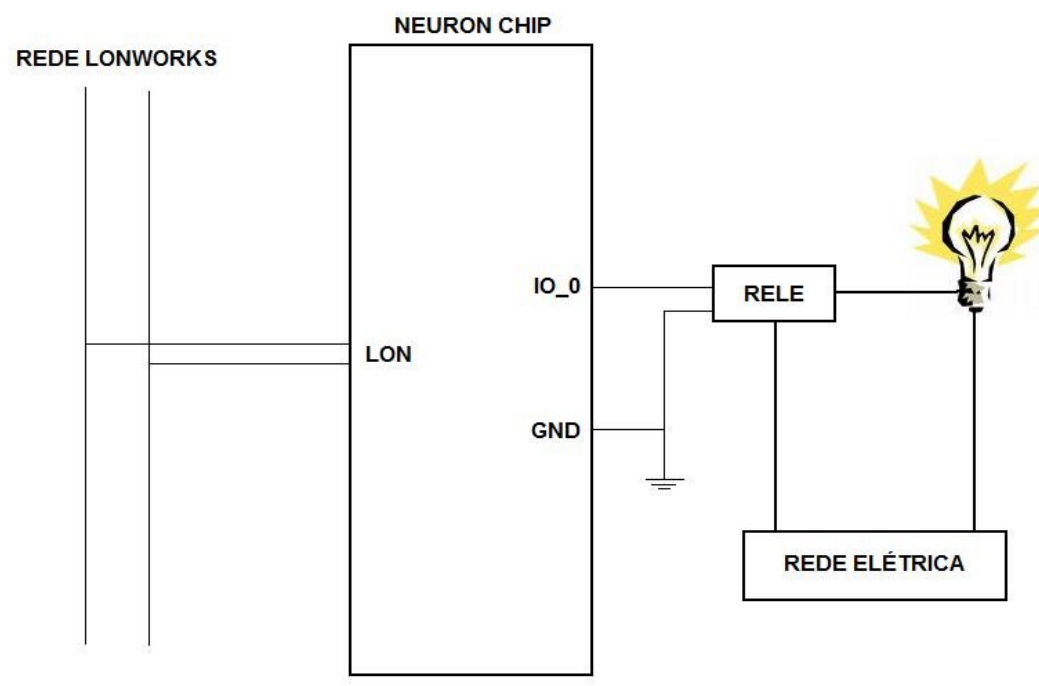

Figura 20 - Esquema de montagem da lâmpada

Neste exemplo, utilizou-se a porta de saída IO_0 como saída para acionamento de um relê, que fecha uma chave com a alimentação da rede elétrica.

Ao receber um comando de ligar a lâmpada, a aplicação no NeuronChip fecha o relê e ao receber um comando de desligar a lâmpada, o NeuronChip comanda a abertura desse relê. A Figura 21 apresenta o desenho esquemático do interruptor: 


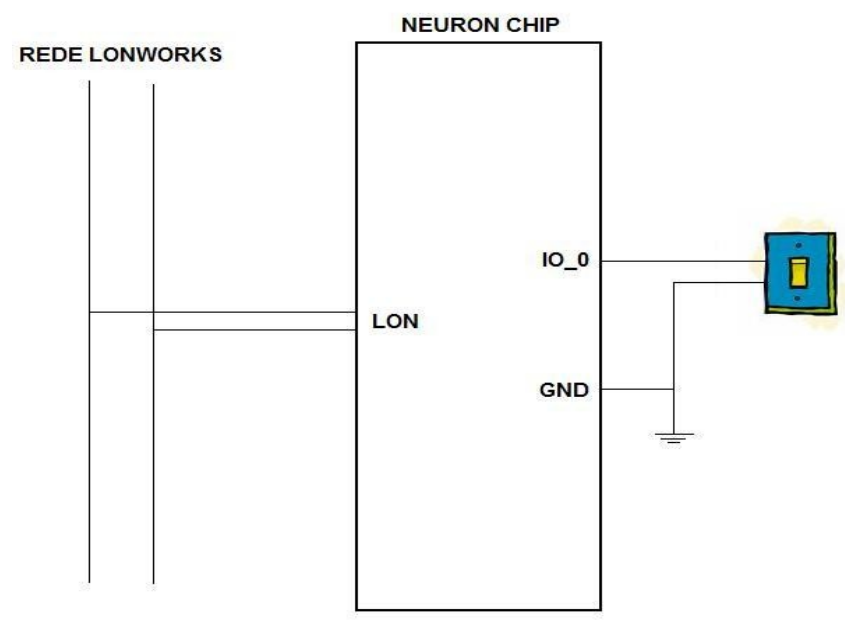

Figura 21 - Esquema de montagem do interruptor

$\mathrm{Na}$ montagem acima, observa-se que o interruptor está conectado diretamente à porta IO_0 do NeuronChip. Neste caso ela foi configurada como uma entrada e não houve necessidade de inserir um resistor de pullup no circuito pois a porta possui um interno, que pode ser habilitado ou desabilitado via software.

Em uma das posições da chave, será obtida a leitura do nível lógico zero na porta e na posição inversa, será obtida a leitura do nível lógico um.

Ao contrário de alguns microcontroladores em que se realiza uma leitura contínua na porta, o NeuronChip trabalha através de eventos. Portanto, basta programar que seja gerado um evento a cada vez que a entrada da porta muda seu estado lógico e o NeuronChip se encarrega de monitorar o estado atual.

Ao mudar o estado lógico da chave ele irá gerar um evento de mudança e chamar a rotina para tratamento da chave. Esse assunto será melhor abordado na próxima seção.

Portanto pode-se observar que o NeuronChip foi desenvolvido para que possa ser utilizado como um microcontrolador qualquer, semelhante aos inúmeros que tem-se disponíveis no mercado.

Porém ele apresenta uma grande capacidade de processamento disponível para a aplicação, além de diversas versões e formatos de estrutura de memória para acomodar desde aplicações pequenas às grandes e toda a capacidade de comunicação em rede embarcada, permitindo o desenvolvimento de redes complexas de controle.

Vale ressaltar que apesar do NeuronChip ser o primeiro e o principal 
microcontrolador utilizado pelos desenvolvedores de produtos LonWorks ${ }^{\circledR}$, atualmente existem outras plataformas e microcontroladores concorrentes.

Um exemplo é o sistema de desenvolvimento criado pela Loytec, que se baseia em um outro conceito, mais voltado para a performance do que custo.

Essa plataforma utiliza um microcontrolador Philips baseado na arquitetura ARM7 de alto desempenho com um sistema de tempo real embarcado. Da mesma forma que a Echelon, a Loytec desenvolveu todo um conjunto de funções para tratamento de mensagens de rede LonWorks ${ }^{\circledR}$ e o adaptou ao sistema operacional para ser embarcado.

Apesar de ter o custo mais elevado do que o NeuronChip, essa plataforma permite o desenvolvimento de dispositivos com grande capacidade de processamento, onde o NeuronChip não pode ser utilizado sozinho.

\subsection{NEURONC}

Para finalizar, será ressaltado como podem ser realizadas as programações do dispositivo nesta tecnologia. Como o sistema utilizado no estudo de caso se baseia nas ferramentas da Echelon, apenas será apresentada esta plataforma.

Com o desenvolvimento do NeuronChip, também foi desenvolvida toda uma plataforma de programação e criação de dispositivos. A Echelon criou ferramentas para a programação do código, compilação, depuração direto no hardware de desenvolvimento, gravação do programa e comissionamento do dispositivo.

A programação do código é realizada em uma ferramenta chamada NodeBuilder, que fornece todas as funções necessárias para tal, como a interface de desenvolvimento do código, compilador e depurador.

O código é escrito em uma linguagem baseada no ANSIC, muito semelhante à linguagem $\mathrm{C}$, chamada de NeuronC. Como a linguagem NeuronC é voltada para o microcontrolador NeuronChip, existem algumas diferenças de linguagem que devem ser observadas, como por exemplo, as definições de tipos, como inteiro etc.

Após desenvolver o programa, ele pode ser compilado nesta mesma 
ferramenta, que apresenta todas as funções necessárias de interfaces de desenvolvimento de código, ou seja, correção de sintaxe, verificação de utilização de tipos etc. Além disso, o compilador verifica a compatibilidade do programa em relação à memória disponível e o hardware utilizado.

A Figura 22, apresenta a interface de programação do NodeBuilder.

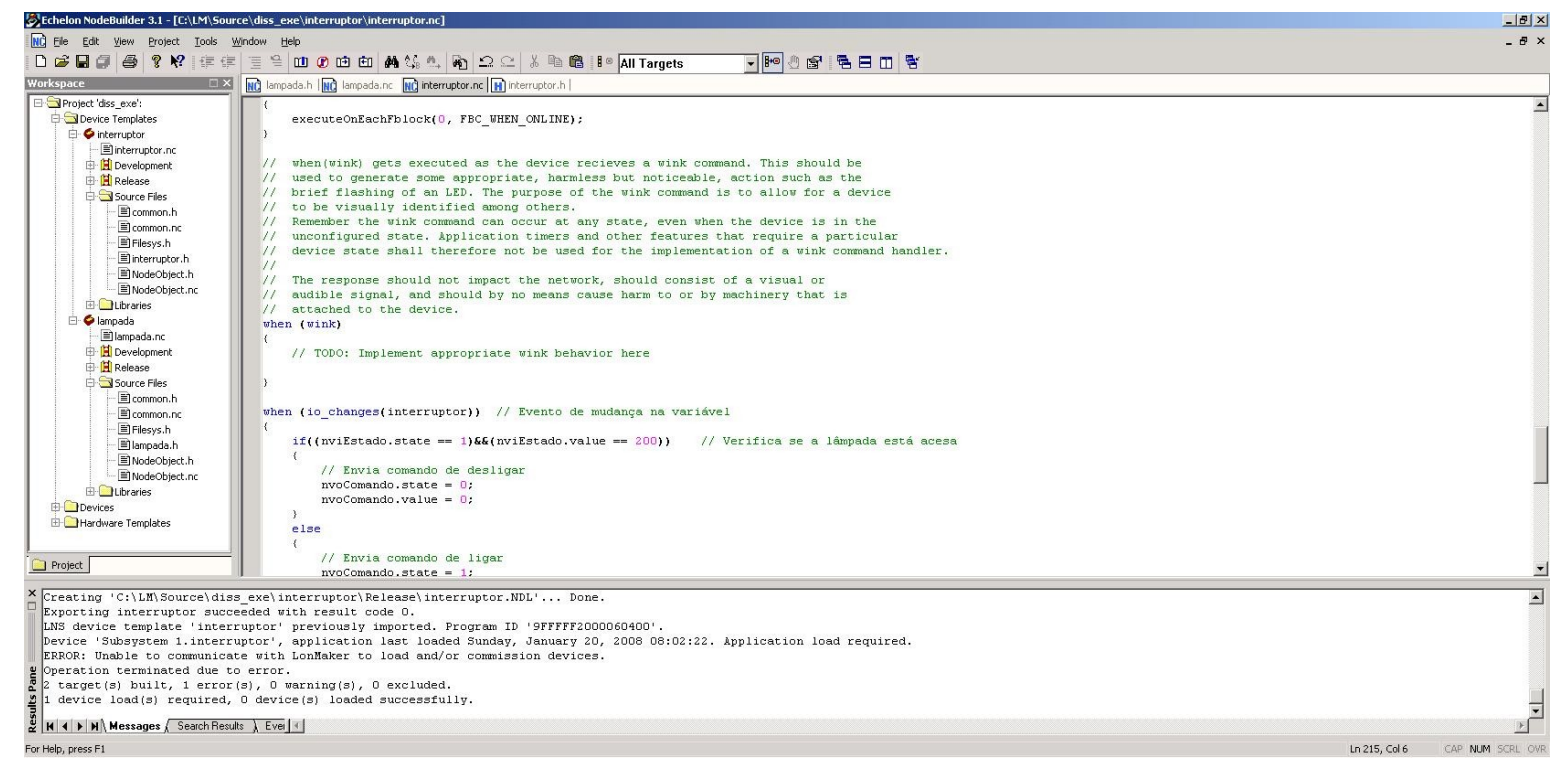

Figura 22 - Tela de exemplo da interface do NodeBuilder

Durante a compilação, existe a opção de adicionar ao programa um kernel de depuração de código, permitindo que ele seja depurado enquanto estiver sendo executado no próprio dispositivo de destino, através da rede de comunicação LonWorks $^{\circledR}$.

Após o programa ter sido compilado, é necessário que ele seja copiado para o dispositivo de destino. Esse processo é realizado através da própria rede LonWorks ${ }^{\circledR}$ com o uso de ferramentas de gerenciamento.

Neste caso, o NodeBuilder se integra diretamente com o LonMaker, de forma que quando é necessário realizar uma baixa de programa, ele acessa diretamente o LonMaker que realiza a operação.

Uma vez que o programa tenha sido copiado para dentro do dispositivo, na maioria dos casos, ele não é executado até que o nó tenha sido comissionado. Para que o programa execute mesmo sem estar configurado em uma rede de controle, é necessário ajustar diretivas de compilação no NodeBuilder.

Uma característica importante de um código em NeuronC é a sua 
orientação a eventos. Diferente de um código em linguagem C não existe uma função principal responsável por inicializar e rodar os programas, ou manter um laço infinito. Nesta plataforma, todo o código executado deve estar associado a um evento.

Podem ser utilizados para disparar ações, eventos provindos da rede de controle, como a atualização do valor em uma variável de entrada, por exemplo, mudanças no estado lógico das portas de entradas, variáveis internas de programação ou, quando se deseja executar sempre uma ação, um evento que é sempre verdade.

A seguir seguem alguns exemplos de eventos que podem ser utilizados:

$$
\begin{aligned}
& \text { when(io_changes(entrada_0) to } 0) \ldots \\
& \text { when(nv_update_occurs(nviComando))... } \\
& \text { when(contador }==15) \ldots \\
& \text { when(TRUE) ... }
\end{aligned}
$$

A Figura 23 contém a imagem de um exemplo de código retirado do NodeBuilder com o evento de recepção do comando do interruptor:

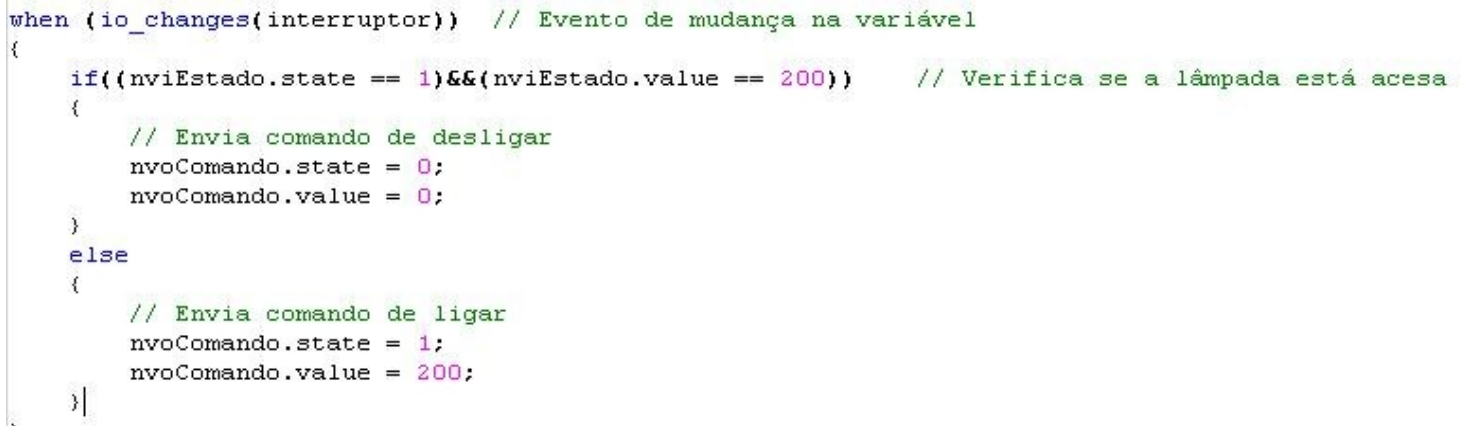

Figura 23 - Exemplo de código em Neuron C

Como muitas vezes exitem grandes seqüências encadeadas de eventos, pode-se utilizar o prefixo priority antes da diretiva when, indicando que este evento deve possuir uma prioridade em relação aos demais na seqüência de execução.

A Figura 24 ilustra como funciona o agendamento de eventos realizado pelo NeuronChip: 


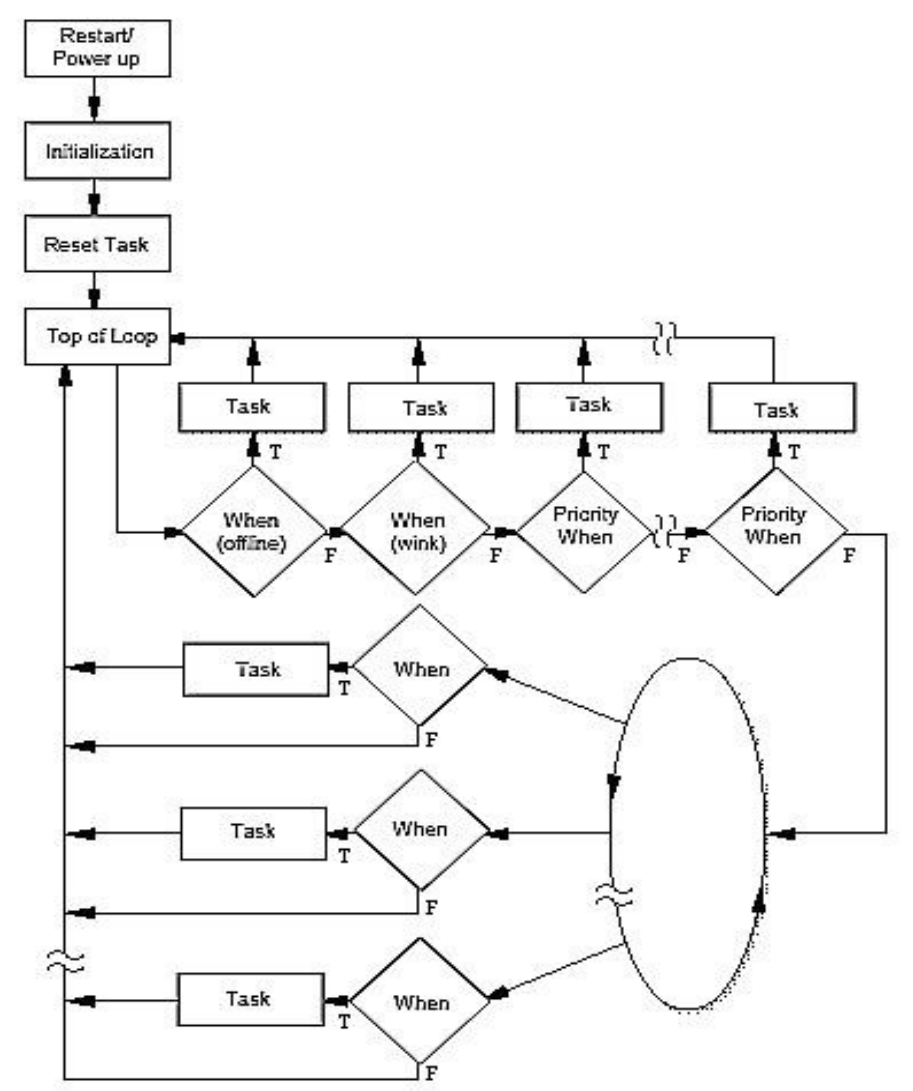

Figura 24 - Sistema de agendamento de eventos (ESTADOS UNIDOS, 1997)

Outro ponto importante nesta linguagem é a forma de tratar uma mensagem de rede. Como se pode observar na Figura 23, a leitura de variáveis de entradas do dispositivo é realizada da mesma forma como se acessa a uma estrutura de linguagem $C$. No exemplo da figura acima, é realizada uma leitura na variável nviEstado, que por sua vez é uma estrutura contento dois bytes, um deles chamado value e outro chamado state.

O mesmo ocorre com a escrita em variáveis de saída. Ainda utilizando o exemplo da Figura 23, observa-se que para enviar o comando para a lâmpada, bastou escrever o valor desejado na variável nvoComando, que tem a mesma estrutura de dados da variável nviEstado.

No caso do interruptor, anteriormente foi definida que ambas as variáveis do nós, ou seja, nviEstado e nvoComando, são variáveis do tipo padrão snvt_switch, o que justifica ambas terem a mesma estrutura de dados. 


\section{O PARADIGMA MULTIAGENTES}

\subsection{INTRODUÇÃO}

Existe a tendência em se utilizar cada vez mais sistemas com arquitetura distribuída em automação (ALVES FILHO, 2001). Assim, é importante a utilização de métodos de desenvolvimento que aproveitem todas as vantagens dessa arquitetura, como por exemplo, o processamento distribuído e paralelo.

Entretanto, os sistemas com arquitetura distribuída podem ser concebidos segundo métodos convencionais, apropriados para sistemas com arquitetura centralizada, desperdiçando grande parte do potencial e vantagens que ele apresenta.

Em alguns casos de aplicação de redes de controle, existem algumas funções como agendamentos de horário ou lógicas de acionamento que são realizados no sistema de supervisão, em um computador ou em algum outro dispositivo centralizador. Dessa forma, esse computador ou dispositivo centralizador nunca poderá ser desligado, pois neste caso os dispositivos não serão acionados no horário desejado ou certos acionamentos não ocorrerão.

Assim, tem-se um sistema com potencial de ser distribuído, mas como foi desenvolvido com algumas funções centralizadas, ele passa a ter o comportamento semelhante ao de um sistema centralizado.

Para que isso não venha a ocorrer, o sistema de supervisão, que poderia ser encarado como uma entidade autônoma, deveria informar aos dispositivos (outras entidades autônomas) os seus respectivos horários de acionamento. Dessa forma, eles passariam a se acionar automaticamente, distribuindo uma função que antes era atrelada a uma única entidade.

Para o desenvolvimento dessas entidades autônomas, podem-se utilizar técnicas de Inteligência Artificial, em especial os sistemas multiagentes, que cada vez mais vêm ganhando destaque em diversas aplicações (SHOHAM, 1991; WOODRIDGE; JENNINGS, 2002). Trata-se de uma área de pesquisa do ramo da Inteligência Artificial que estuda sistemas constituídos por diversas partes menores e autônomas, chamadas de agentes, que trabalham em conjunto com o mesmo objetivo final, interagindo entre si e se organizando de forma eficiente (LIVIU; SEAN, 2004). 
Encontra-se exemplos de aplicação, com diferentes implementações e campos de atuação, desde sistemas compostos por agentes complexos, com altos graus de cognição, até sistemas compostos por agentes formados por conjuntos de regras simples (DURFEE; ROSENCHEIN, 1994).

Sistemas multi-agentes representam uma tendência que está emergindo como uma nova e poderosa tecnologia, inclusive indicando que esse tipo de desenvolvimento pode vir a ser considerado como novo paradigma de propósito geral para desenvolvimento de software (ZAMBONELLI; OMICINI, 2004), como o que ocorreu com a chegada da Programação Orientada a Objetos em um cenário onde predominava a programação procedural.

Agentes podem ser entendidos como autômatos, reais ou virtuais, que possuem um conhecimento do ambiente e são capazes de interpretá-lo e perceber as suas modificações. Possuem capacidade de percepção e comunicação com outros agentes, podendo fazer inferências sobre eles, classificando-os, formando grupos de interesse comuns ou até mesmo rejeitando aqueles mal intencionados. Por fim, são capazes de decidir conforme suas observações, objetivos, conhecimentos e interações (WOODRIDGE; JENNINGS, 2002).

\subsection{TIPOS DE AGENTES}

A forma mais comum de classificar os agentes leva em consideração a sua capacidade de deliberação, percepção do ambiente e complexidade de comunicação. Dessa forma, existem dois grandes grupos, um deles chamado de agentes reativos e o outro de agentes cognitivos.

\subsubsection{Agentes Reativos}

Dentro do grupo dos agentes reativos estão aqueles que são capazes de perceber (ainda que de forma bastante limitada) e reagir, atuando sobre o ambiente em que estão inseridos, conforme uma lógica pré-definida e sempre com um objetivo final que foi estipulado em período de projeto.

Uma característica marcante desse tipo de modelo é a sua forma simples de comunicação, que muitas vezes se dá de maneira indireta, através do próprio ambiente (WOODRIDGE; JENNINGS, 2002). 
A grande vantagem de agentes com essas características é a sua facilidade de programação, a possibilidade de utilização de equipamentos de menor capacidade de processamento e grande limitação de energia.

Apesar de parecerem bastante limitados, eles são muito utilizados em sistemas com características de hardware conforme citado acima, como por exemplo, exploração de minério em locais inóspitos.

Também são bastante utilizados para estudar o comportamento de insetos e seus processos de desenvolvimento como demonstrado em Liviu e Sean (2004), ou em redes de controle com dispositivos com baixa capacidade de processamento (CUNHA; CUGNASCA; CHERMONT, 2005). Enfim, essa classe de agente é utilizada em sistemas onde se espera que a inteligência surja do comportamento global da sociedade, e não de cada indivíduo (STEELS, 1990; CASTELFRANCHI, 1998; BOISSIER; DEMAZEAU, 1994).

\subsubsection{Agentes Cognitivos}

Já o grupo dos agentes cognitivos engloba aqueles que possuem funcionalidades muito mais complexas e modelos que exigem um grau de processamento muito maior do que o grupo anterior (WOODRIDGE; JENNINGS, 2002).

Por se tratar de um tipo de programação mais complexa do que as utilizadas no caso de agentes reativos, foram desenvolvidas diversas arquiteturas de agentes, sendo que a mais utilizada atualmente é a "Beliefs, Desires, Intentions" (BDI), crenças, desejos e intenções (RAO, 1996; RAO; GEORGEFF, 1991).

Essa arquitetura divide os processos de tomada de decisão e a informação contida em um agente cognitivo, de forma que nas suas crenças encontra-se toda a informação que ele possui a respeito do ambiente, do seu estado atual e de outros agentes (RAO, 1996; RAO; GEORGEFF, 1991). Toda a inferência que o agente possui, é armazenada neste banco de dados, e toda a sua decisão é embasada pelo conhecimento contido nele, inclusive, o agente cognitivo pode armazenar formas de aprender, ensinadas por outros agentes.

Os seus desejos representam tudo que o agente gostaria de fazer. Normalmente, eles estão atrelados a um ou mais objetivos finais, que foram 
programados pelo seu desenvolvedor (RAO, 1996; RAO; GEORGEFF, 1991) e são as ações que ele gostaria de tomar para que se aproxime desses objetivos. É importante perceber que seus desejos não estão limitados ao estado atual do ambiente, da sociedade ou limitações do próprio agente, de forma que ele poderia ter desejos inatingíveis.

Por fim, as intenções podem ser entendidas como uma filtragem de seus desejos, de forma que são escolhidos aqueles mais factíveis de serem realizados e que através de algum algoritmo, como o de menor caminho, por exemplo, o aproxima de seu objetivo final (RAO; GEORGEFF, 1991; COHEN; LEVESQUE, 1990).

Através dessa arquitetura já é possível perceber que a complexidade de um agente cognitivo se assemelha muito com a do ser humano e é muito maior do que a de um agente reativo. Além disso, pode-se perceber que ele é uma entidade autônoma e inteligente por si só, ao contrário do que acontece com os agentes reativos, aonde a inteligência vem do sistema e não da individualidade.

A finalidade de programar agentes como esses é a concepção de um sistema onde eles sejam capazes de trocar informações complexas, de possuir e construir modelos completos do mundo em que estão inseridos, de si próprios e dos outros agentes e assim, agir espontaneamente criando uma organização que atenda a um objetivo comum a todos eles (STEELS, 1990). Um bom exemplo da utilização de agentes cognitivos está em Bigham (2003). Neste exemplo existe uma cadeia de antenas de celulares, cada qual com a sua área de abrangência gerenciável de forma que intersecções entre elas podem ser feitas e desfeitas.

Como forma de decidir qual seria a área de abrangência utilizada por dada antena, cada uma foi modelada como um agente cognitivo com a capacidade de conversarem entre si e decidirem com base em estimativas de cargas no local, como seria dividida a cobertura. Ao fim do experimento, obteve-se áreas de coberturas irregulares e que se modificavam ao longo do tempo, de forma a atender aos requisitos do projeto. 


\subsection{SOCIEDADES DE AGENTES E RESOLUÇÃO DISTRIBUÍDA DE PROBLEMAS}

A idéia central de sistemas multiagentes é a criação de sociedades de entidades autônomas capazes de resolver problemas que podem ou não ter sido previstos durante a fase de sua concepção, extrapolando a inteligência do seu criador (ou criadores). Neste ponto, existe uma divergência na comunidade de Inteligência Artificial, pois se a sociedade de agentes somente é capaz de resolver um conjunto limitado de problemas (motivo de sua criação), alguns pesquisadores deixam de denominá-la sistema multiagente, mas sim de solução distribuída de problemas (DURFEE; ROSENCHEIN, 1994).

Uma outra característica importante que um sistema multiagentes normalmente apresenta é a inexistência de um controle centralizado; assim, torna-se necessário uma forma de organizar e coordenar as ações de cada agente em particular.

Isso é feito, como acontece na sociedade humana, através da implementação de regras sociais (como protocolos de comunicação e negociação) (ROSENSCHEIN; ZLOTKIN, 1997) e, em alguns casos, pela especificação de hierarquias de papéis (os agentes para entrarem na sociedade devem assumir papéis segundo um modelo de organização pré-estabelecido) (HÜBNER; SICHMAN; BOISSIER, 2002).

Essa descentralização acentua a característica autônoma dos agentes, e em última instância cria, a possibilidade da existência de sistemas totalmente abertos, onde se permite a entrada e saída de agentes diversos, desde que eles respeitem as normas da "sociedade". O quadro geral do conceito pode ser resumido da seguinte forma: sistemas multiagentes são sistemas que imitam e reproduzem o comportamento de sistemas sociais do mundo real (WOODRIDGE; JENNINGS, 2002). 


\section{SISTEMA DISTRIBUÍDO DE COMUNICAÇÃO TELEFÔNICA PRIVADA (SDCTP)}

Atualmente um sistema indispensável para qualquer empresa de pequeno à grande porte, é um sistema de comunicação interno que se integra com as linhas de telefones fornecidas pelas concessionárias.

Esse sistema privado de telefonia visa agilizar a comunicação entre as pessoas da empresa, principalmente entre aquelas que se encontram em áreas diferentes, separadas por estruturas físicas como paredes, divisórias etc.

Outra função importante desse sistema é permitir que a empresa possua uma grande quantidade de linhas telefônicas para receber e realizar chamadas, sempre dando vazão à comunicação.

Este Capítulo apresenta e discute os sistemas de comunicação telefônica normalmente utilizados em empresas, contrapondo-os com um novo sistema em fase de pesquisa que visa substituí-los com vantagens. Tais informações e discussões serão utilizadas no capítulo subseqüente, que utilizará a proposta deste trabalho para viabilizar o novo sistema.

\subsection{SISTEMA LEGADO}

O equipamento que permite a execução dessas tarefas é chamado de PABX (AGÊNCIA NACIONAL DE TELECOMUNICAÇÕES, 2004), e de forma semelhante ao que ocorre com os sistemas de automação, utiliza uma topologia centralizada. Ele é comercializado por diversos fabricantes, como a Siemens, Panasonic, Intelbras etc, sendo um equipamento consagrado no mercado (SIEMENS, 2009; PANASONIC, 2009; INTELBRAS, 2009).

A Figura 25 é um diagrama detalhando a topologia que é utilizada no PABX: 


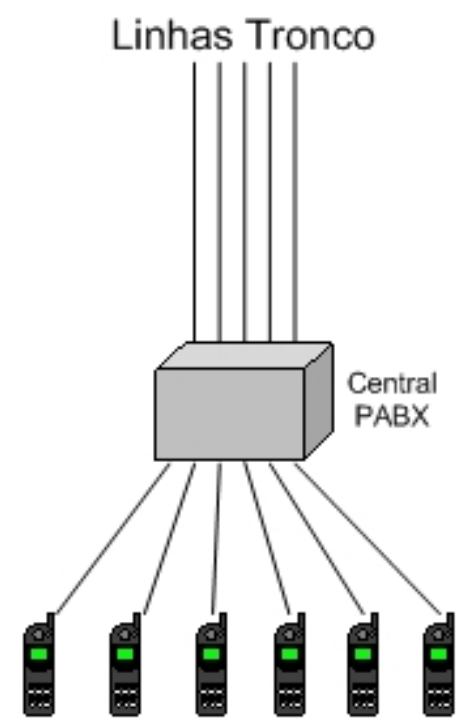

Ramais

Figura 25 - Topologia de uma PABX centralizado

Como mostrado na Figura 25, da central de PABX partem todos os ramais que estarão disponíveis, sendo que na grande maioria dos casos, cada ramal necessita de um par de fio trançado exclusivo.

Assim como os ramais as linhas de telefones provindas da concessionária, também denominadas linhas troncos, devem ser todas conectadas à central do PABX, permitindo que os ramais recebam e realizem ligações para fora da empresa.

Semelhante aos sistemas de automação centralizados, as centrais de PABX desse tipo possuem algumas desvantagens em relação aos sistemas distribuídos. No caso de a central de PABX parar de funcionar, a empresa toda não poderá se comunicar entre seus ramais internos ou com os troncos externos.

Outra desvantagem diz respeito à expansibilidade do sistema e no caso de falhas parciais. Caso algum ramal deixar de funcionar, por problemas no PABX por exemplo, deve-se utilizar outro ramal disponível.

Existe também o caso em que se deseja aumentar o número de ramais de uma empresa, que normalmente apresenta uma capacidade limitada de expansão, exigindo a troca do equipamento por outro de maior capacidade. Essa troca pode gerar gastos desnecessários para a empresa, uma vez que nem sempre se tem disponível o número exato de ramais desejados.

Tomando por exemplo o caso da empresa ter oito ramais e 
necessitar de mais um, ela será obrigada a descartar a sua central atual e comprar outra de dezesseis ramais, pois é o único tamanho de central disponível no mercado que atende a sua necessidade. O mesmo pode ocorrer caso se deseja aumentar o número de linhas tronco. Em ambos os casos, a troca ou reparo implica em indisponibilidade do sistema.

Outro problema importante diz respeito à estrutura de cabeamento da empresa. Apesar de já se utilizar o conceito de cabeamento estruturado, deve-se sempre haver um par trançado da central de PABX para o local onde se encontra instalado o ramal.

Ainda que existam sistemas de PABX digitais e que muitas vezes integram os sistemas de comunicação através da Internet, a topologia centralizada ainda persiste, assim como a estrutura de cabeamento.

\subsubsection{Funções Desempenhadas pelo PABX}

Além de desempenharem as funções básicas citadas acima, que permitem a comunicação entre ramais e entre ramal e linha tronco, as centrais de PABX também podem realizar muitas outras, dependendo do modelo escolhido e das necessidades do cliente.

Uma função básica de um PABX é receber as chamadas externas e transferi-las para o ramal responsável por atendê-las. Esse ramal é chamado de ramal atendente e pode pertencer a uma pessoa ou estar conectado a um dispositivo que realiza o atendimento automatizado, conhecido como atendedor automático, que é responsável por receber as ligações e apresentar um menu de voz com os ramais que se pode chamar.

Esse tipo de equipamento pode fazer parte da central de PABX ou ser um equipamento independente a ela. Ele é muito utilizado em grandes empresas, como bancos e call centers, para agilizar e direcionar o atendimento.

No caso do ramal atendente estar ocupado, o PABX pode direcionar a chamada para outros ramais, que funcionam como atendentes secundários, ou passar a chamada para um estado de espera telefônica.

A função de espera telefônica pode ser realizada pelo próprio PABX sendo interna à central ou através de um dispositivo externo, acoplado através de 
alguma entrada especial, diferentemente do atendedor automático, que está conectado como um ramal.

Outra função importante do PABX é permitir que os ramais internos realizem chamadas externas, através de alguma das linhas troncos disponíveis. Neste caso, o usuário deverá solicitar que o PABX realize uma chamada externa digitando um número pré-programado no teclado do telefone.

Ao digitar esse número, o PABX deverá fornecer ao usuário uma linha livre para que ele realize o telefonema desejado, que pode ser escolhido aleatoriamente ou através de um procedimento pré-definido.

No caso de não haver nenhuma linha disponível ou de o ramal ou usuário não estar habilitado a realizar a ligação, o PABX deverá indicar o fato ao usuário, como por exemplo, com o tom de ocupado.

Apesar de existirem outras funções avançadas, apresentou-se as principais funções encontradas nos sistemas de PABX típicos, que foram citadas por serem utilizadas nos itens subseqüentes.

\subsection{PABX DISTRIBUÍDO}

Como alternativa à esse sistema de PABX centralizado, o doutorando Miguel do Santos Alves Filho está desenvolvendo, em conjunto com a empresa Conceito Tecnologia e com apoio e financiamento da Fundação de Amparo à Pesquisa do Estado de São Paulo (FAPESP), através dos projetos 03/0443-6 e 05/5604-6, um novo sistema de PABX.

O SDCTP, como o próprio nome diz, é um sistema de telefonia distribuído que vem sendo concebido a partir de uma tecnologia aberta, e objetiva oferecer os serviços típicos de telefonia que um PABX convencional oferece, porém através de uma rede de controle que segue o padrão LonWorks ${ }^{\circledR}$.

Diferentemente de um sistema PABX convencional, o SDCTP é constituído por diversos dispositivos (ou módulos) dispersos em uma rede de controle, que trabalhando em conjunto irão realizar as mesmas funções de um PABX.

Diversos tipos diferentes de dispositivos vêm sendo concebidos para atender as necessidades do usuário. Por exemplo, conceberam-se módulos que 
desempenham a função de: ramal, tronco, atendimento automático, outro espera telefônica etc.

A Figura 26 apresenta a topologia de um sistema de PABX utilizando o SDCTP:

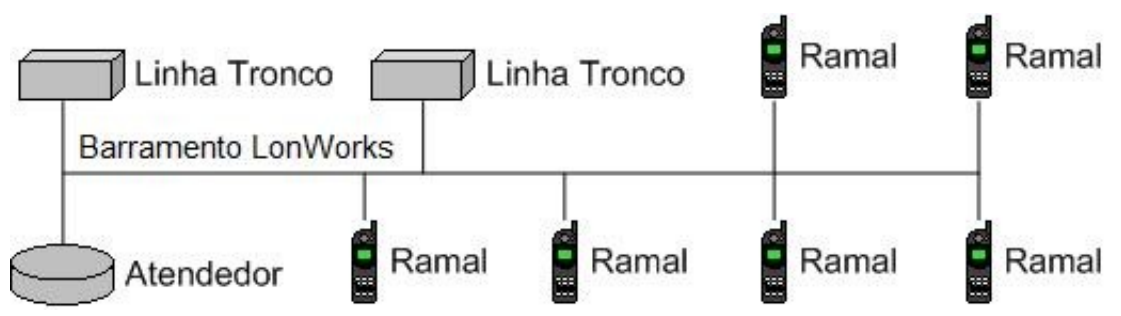

Figura 26 - Topologia do PABX distribuído

Através dessa topologia, pode-se fazer uso do conceito de custo efetivo, ou seja, o usuário adquire apenas os equipamentos que realmente necessita, (por exemplo, adquirindo apenas o número de módulos de ramais que realmente necessita, uma vez que a expansão é realizada de forma simples), não imobilizando capital de forma desnecessária através de equipamentos superdimensionados.

Outra vantagem de utilizar um sistema de telefonia como o SDCTP está na estrutura física necessária para o seu funcionamento. No caso de um sistema centralizado como o PABX citado anteriormente, cada ramal necessita de um cabo próprio até a central.

Já em um sistema onde os ramais possam ser dispostos em uma rede, basta um cabo que interliga todos os módulos de rede, reduzindo a quantidade de cabos necessários barateando e facilitando a instalação e ampliação do sistema, sendo este um conceito base da tecnologia LonWorks ${ }^{\circledR}$ e das redes de controle (ECHELON CORPORATION, 1999).

Como atualmente existe uma enorme base instalada de sistemas centralizados de PABX, seria difícil a aceitação de um sistema totalmente novo, que necessitasse o investimento para a troca de algo que já se encontra em funcionamento.

Em vista disso, concebeu-se o SDCTP para também ser integrado a um PABX em funcionamento, atuando como uma ampliação do mesmo. Essa característica faz com que não seja necessária a troca do equipamento, requerendo 
apenas a sua configuração para trabalhar em conjunto com o SDCTP.

Para demonstrar como isso pode ser feito, será tomado como exemplo um cenário em que se tenha um PABX com todos o seus ramais utilizados, não sendo possível mais expansão e se necessita acrescentar mais um ramal.

Normalmente o sistema de PABX deveria ser substituído por um novo que suporte mais ramais. Como citado anteriormente, muitas vezes é difícil encontrar uma central que possua exatamente essa quantidade, devendo-se adquirir uma nova que ficará com ramais livres, ou seja, superdimensionada.

Outra opção é utilizar o SDCTP para ampliar a quantidade de ramais, sendo que para isso o usuário deverá adquirir um módulo de linha tronco (MLT) e dois ramais digitais ou analógicos (na seção posterior serão detalhados os módulos que compõem o SDCTP).

O Módulo de linha tronco será ligado a um ramal do PABX legado e interconectado com os dois módulos de ramais. Assim, do ponto de vista do PABX legado, o sistema novo será tratado como apenas um ramal. Já do ponto de vista dos ramais que estão na rede do SDCTP, o sistema legado será tratado com se fosse uma ligação externa.

Essa ligação pode ser observada na Figura 27:

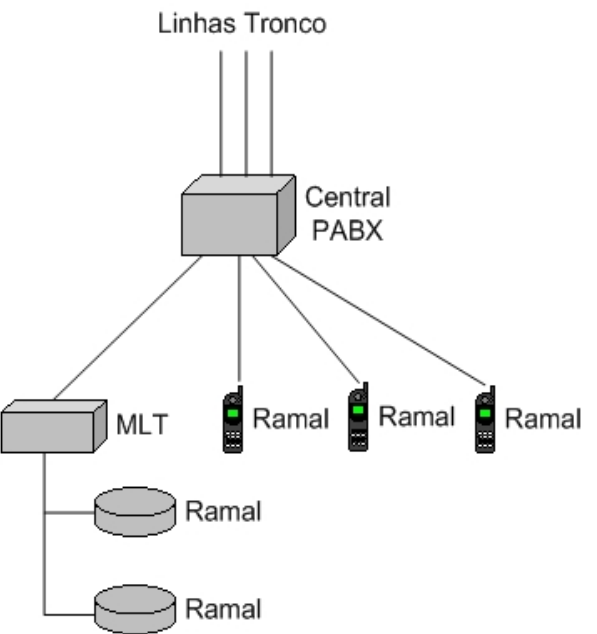

Figura 27 - Ampliação de ramais com o SDCTP

O SDCTP, portanto, é um sistema de comunicação que visa também oferecer ao usuário todas as funcionalidades que ele já possui operando em conjunto com os sistemas atuais (ou sistemas legados), porém acrescentando a confiabilidade e versatilidade dos sistemas distribuídos e de redes de controle. 
Para finalizar, cabe destacar que como a plataforma básica do SDCTP é um sistema de controle aberto e um dos mais utilizados no mundo em automação predial, existe um bom potencial para integrar a telefonia com a automação predial, gerando uma nova categoria de produto.

O novo sistema poderá ser utilizado como uma interface usuáriomáquina para o sistema de automação predial fornecendo ao usuário o controle através de voz, economizando uma interface equivalente que seria necessária no sistema de automação predial.

Informações como temperatura ambiente, velocidade de ventilação, pontos de operação de aparelhos de ar condicionados poderão ser obtidos pelo usuário através do próprio telefone.

Da mesma forma, comandos enviados ao sistema de controle poderão ser realizados através do telefone (por exemplo, ajustes de pontos de operação do ar condicionado).

\subsubsection{Módulos de Rede}

Por concepção o SDCTP é um sistema modular de forma que cada funcionalidade pode estar relacionada a um ou mais dispositivos físicos diferentes. Portanto, para entender melhor o seu funcionamento, deve-se conhecer os módulos para ele concebidos.

- Módulo de Linha Tronco (MLT)

É responsável por interconectar as linhas Public System Telefony Network (PSTN), cujas linhas troncos são fornecidas pela concessionária de telefonia fixa, com os ramais internos do SDCTP. É através dele que os usuários realizam ou recebem ligações externas. Ele também armazena programações e configurações como políticas de acesso às linhas externas.

- Módulo de tronco E1 (ME1)

Funciona exatamente da mesma forma que o MLT, com a diferença que ao invés de integrar ao sistema uma linha tronco analógica da PSTN, integra um tronco E1 digital, que pode conter até 31 linhas diferentes. 
- Módulo de Telefonia Digital (MTD)

Este módulos são interfaces usuário-máquina que permitem a realização de chamadas e a realização de configurações, inclusive em outros módulos na rede.

Ele pode se comunicar par-a-par com qualquer outro módulo na rede e utilizar os serviços disponíveis. Neles também se encontram configurações como ramal atendente, área e pessoa a qual pertence etc.

- Módulo de Telefonia Analógico (MTA)

Funciona exatamente como o MTD, com a diferença que ele fornece uma interface para que qualquer telefone analógico legado possa ser conectado e passe a fazer parte do sistema de sinalização digital do SDCTP.

- Módulo de Resposta Audível (MRA)

É responsável pelo armazenamento de mensagens de sons de interesse, como trilhas sonoras disponíveis no sistema. Pode atuar também como secretária eletrônica, atendimento automático e espera telefônica.

- Módulo Gate Keeper (MGK)

É responsável por integrar o sistema de telefonia entre duas filiais separadas de uma mesma empresa através da Internet, fazendo com que o sistema funcione como se todos os ramais estivessem na mesma localização física.

\subsubsection{Enlaces Telefônicos}

Com a finalidade de manter o sistema com a topologia distribuída, cada módulo de rede é capaz de se comunicar com o outro diretamente, ou seja, a comunicação entre os dispositivos é par-a-par.

Quando um dispositivo deseja se comunicar com outro, deve ser realizada uma conexão lógica entre eles sem que haja nenhum intermediário. Esse processo pode ser comparado ao processo de fechamento de enlaces telefônicos realizados pela centrais públicas e pelo PABX privado, com a exceção de que, neste 
caso, não há central.

Do ponto de vista lógico, quando um dispositivo deseja se comunicar com o outro, eles devem negociar e formar um canal de comunicação. Na rede LonWorks $^{\circledR}$, esse canal de comunicação pode ser um binding de variável.

Para exemplificar esse processo dentro da rede LonWorks ${ }^{\circledR}$, pode-se utilizar o exemplo em que um MTD necessita se comunicar com outro MTD, ou seja, uma ligação entre ramais dentro de uma rede já instalada com outros dispositivos. A Figura 28 apresenta o diagrama de um sistema com o cenário descrito.

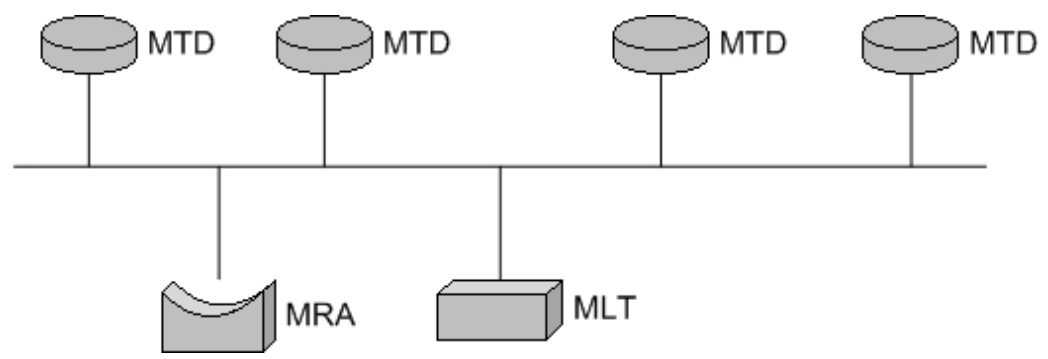

Figura 28 - Cenário de exemplo de um sistema instalado

Supondo que inicialmente ambos os MTDs estejam em um estado de espera, ou seja, estão livres para realizar ou receber ligações. O usuário irá retirar o telefone do gancho e discar o ramal de destino.

Neste momento, o MTD de origem deverá se comunicar com o MTD de destino, perguntando se o mesmo se encontra livre para receber uma ligação. Com uma resposta positiva, o enlace telefônico lógico é estabelecido, que implica na realização de um binding entre as variáveis que permitam a comunicação entre eles (Figura 29). Em caso negativo, o usuário que discou o ramal ouvirá o tom de ocupado.

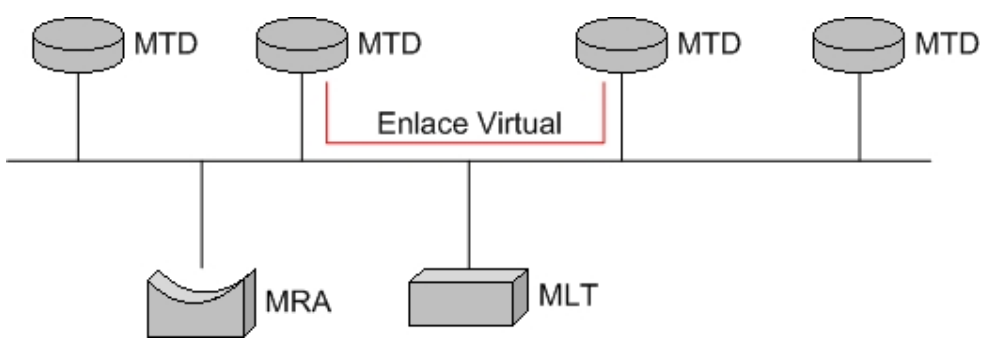

Figura 29 - Enlace virutal formado entre dois MTDs

Depois de finalizada a ligação, esse enlace telefônico deve ser 
desfeito, fazendo com que os MTDs retornem ao estado de espera para que possam receber ou realizar outras chamadas.

Da mesma forma que existem enlaces entre MTDs, podem haver outros enlaces entre qualquer dispositivo disponível na rede, como por exemplo: MTD e MTA, quando for uma chamada entre ramais; MTD ou MTA e MRA, no caso em que se esteja utilizando uma secretária eletrônica; MTD ou MTA e MLT ou ME1, no caso de uma chamada externa; e MLT ou ME1 e MRA, no caso de um atendimento automático ou espera telefônica.

Poderia se pensar em uma solução em que todos esses possíveis enlaces fossem previamente configurados de forma que somente fossem ativados aqueles necessários em dado momento (Figura 30).

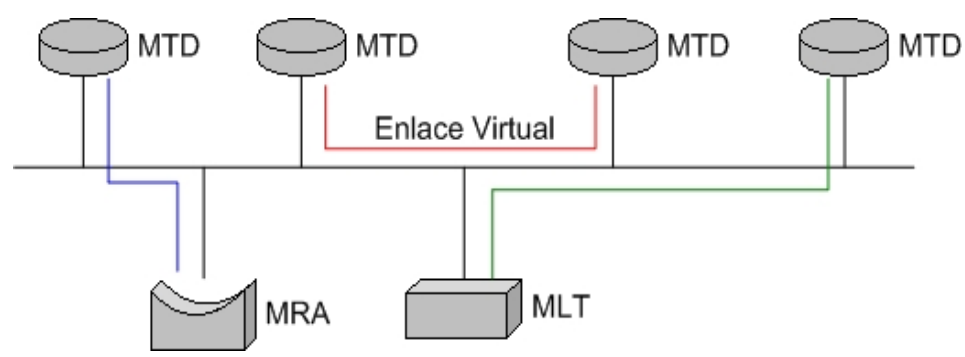

Figura 30 - SDCTP com diversos enlaces simultâneos

No entanto, como se pode observar, existe uma enorme possibilidade de interligações entre módulos que podem ser feitas, além disso, um sistema pode ter muitos MTDs, MTAs, MLTs etc, o que pode gerar uma quantidade muito grande de possíveis conexões.

Essa enorme combinação de possíveis enlaces, impossibilita que todos eles sejam previamente programadas, tanto devido à limites na própria tecnologia como devido à enorme quantidade de horas de engenharia necessária à sua programação.

Outra solução seria a de utilizar operadores que fizessem e desfizessem esses enlaces à medida que eles fossem necessários utilizando-se de interfaces para a rede de controle.

No entanto, a possibilidade de ocorrerem muitas ligações simultâneas poderia fazer com que fossem necessários muitos funcionários disponíveis somente para essa tarefa, tornando lenta a resposta do sistema. 
Portanto, a melhor solução para esse problema é fazer com que os módulos sejam capazes de negociar e realizar esses enlaces dinamicamente de forma autônoma e sem interferência humana. E, para executar essa tarefa, podemse somar as técnicas de sistema multi-agentes com o conhecimento de como funciona um binding nesta tecnologia, ambos apresentados em capítulos anteriores, para automatizar todo esse processo.

Sem uma solução como essa, que torne esse processo automatizado, não há como prosseguir com o desenvolvimento do SDCTP. 


\section{GERENCIAMENTO DINÂMICO}

O presente capítulo apresenta como foi realizado todo o planejamento e desenvolvimento do processo, assim como a apresentação dos requisitos do sistema, a metodologia aplicada e os materiais utilizados. Também são apresentadas as etapas envolvidas no desenvolvimento do processo e seu planejamento através de diagramas de seqüência e diagramas de fluxo.

Por fim, os resultados obtidos através da aplicação do processo desenvolvido foram discutidos com base no levantamento de dados que comprovam a eficiência do processo frente a processos realizados através de sistemas de gerenciamento de rede LonWorks ${ }^{\circledR}$, como o LonMaker da Echelon.

\subsection{MATERIAIS E MÉTODOS}

\subsubsection{Metodologia}

Como se pôde observar através dos capítulos anteriores, essa pesquisa envolve para a sua validação o projeto e desenvolvimento de software para dispositivos com capacidade de processamento e quantidade de memória limitadas se comparado com computadores.

O projeto e implementação de sistemas com as características do presente trabalho costumam ser conduzidos com eficiência quando se adota uma metodologia de desenvolvimento compatível com as suas particularidades (SOARES, 1993; PAZ, 2002). Por se tratar de um projeto associado a uma pesquisa, alterações nas soluções costumam ser freqüentes. Após a obtenção de uma primeira versão de um subsistema desenvolvido, a sua utilização não conclui o processo de desenvolvimento de um projeto, pois ao se introduzir modificações na mesma, ela pode gerar novas demandas, levando a uma redefinição do problema original, reiniciando o ciclo de desenvolvimento, agora com o problema ligeiramente redefinido.

Tem-se assim a espiral evolucionária, comum em projetos de engenharia, discutida por Soares (1993) e Paz (2002), e apresentada na Figura 31. 


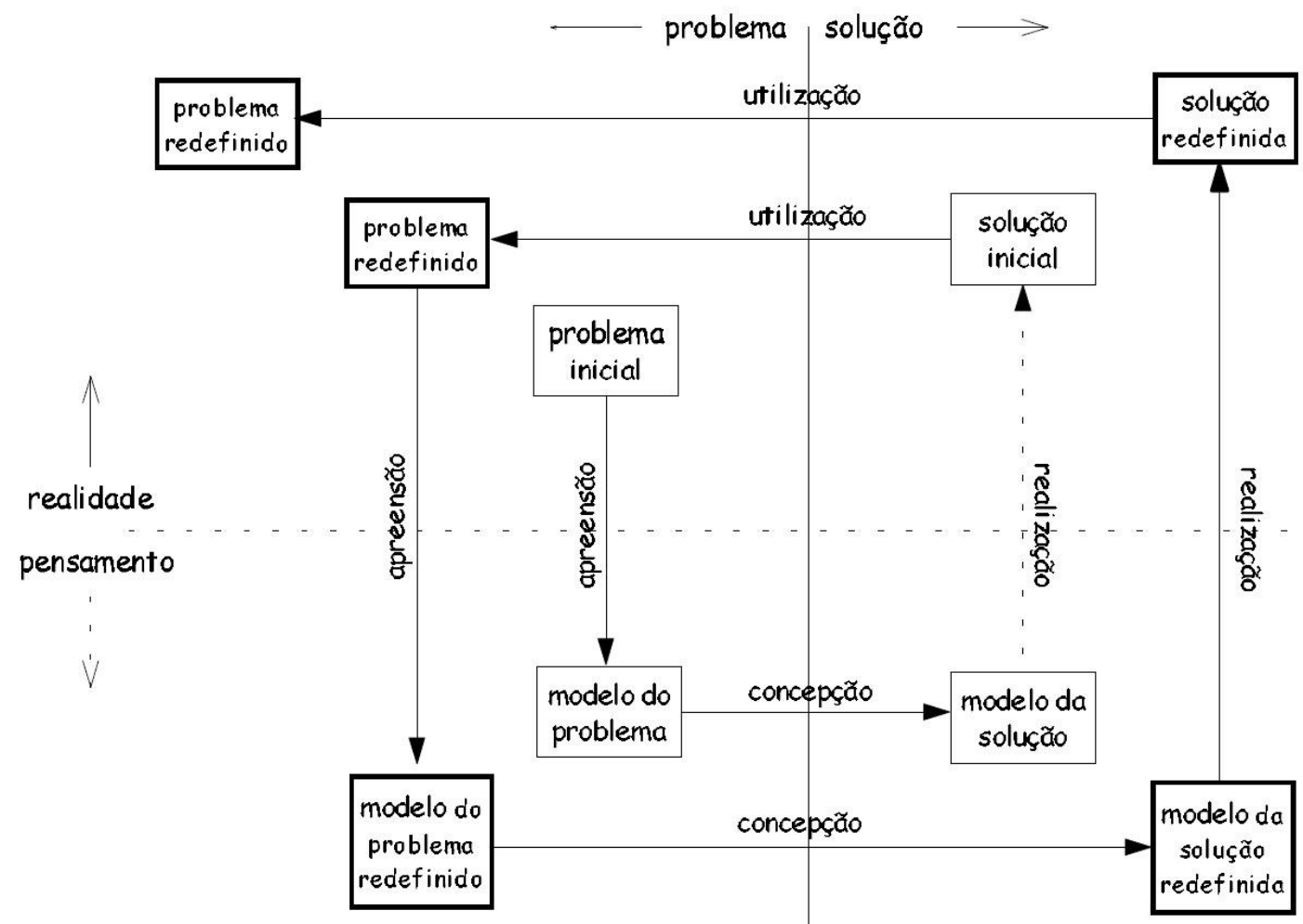

Figura 31 - O aspecto evolucionário do desenvolvimento de projetos de Engenharia (PAZ, 2002)

Como se pode observar, ele é semelhante ao modelo em espiral, mais comumente utilizado na engenharia de software, e é dividido em etapas incrementais.

O fato de ser um processo incremental permite que o sistema se torne tão sofisticado quanto exigido, evitando trabalho desnecessário, garantindo que todos os requisitos sejam atingidos e que possa haver a adição de outros novos requisitos que venham a ser descobertos ao longo do projeto.

\subsubsection{As Etapas da Metodologia}

A primeira etapa, chamada de problema inicial, se constitui apenas no levantamento de um problema baseado em uma necessidade real. Aqui não são levantadas possíveis soluções, apenas requisitos.

Na segunda etapa, modelo do problema, deve-se gerar uma forma de modelar o problema, lançando mão de recursos como diagramas de fluxos de dados, casos de uso, diagramas de seqüência, ou seja, deve-se utilizar todas as ferramentas de modelagem disponíveis para torná-lo inteligível e livre de 
ambigüidades.

$\mathrm{Na}$ terceira etapa, da mesma forma que na etapa anterior, deve-se utilizar as ferramentas que se julgar mais adequadas para modelar a solução do problema. Deve-se torná-la visível e sem ambigüidades, procurando sempre estudar sua eficácia ao atender os requisitos levantados na etapa anterior, e permitir que através do estudo dessa modelagem a solução possa ser implementada em qualquer ambiente que supra as suas necessidades.

Por fim, fazendo-se uso do modelo gerado na solução, deve-se desenvolver um protótipo inicial para estudos e verificação da eficácia da solução em relação aos requisitos levantados.

A partir de agora, o modelo se torna incremental, pois ele se baseia na solução gerada até o momento. Nesta nova etapa, deve-se levantar os pontos falhos ou passíveis de aprimoramento, ou até mesmo identificar novos requisitos que apenas afloraram após a experimentação da solução inicial. Assim, todo o ciclo se repete algumas vezes até a obtenção de uma solução realmente satisfatória.

\subsubsection{Materiais}

Para o desenvolvimento da pesquisa foram utilizados os seguintes recursos:

- Nós compatíveis com o padrão LonWorks ${ }^{\circledR}$ (ECHELON CORPORATION, 1997):

Nos nós foram gravadas aplicações usuais com a finalidade de testar a implementação realizada, possibilitando o levantamento de possíveis falhas de desenvolvimento ou até mesmo de projeto.

Utilizou-se dois nós, pois os processos de comissionamento e bindings dinâmicos envolvem a troca de informação entre dispositivos.

Como parte do SDCTP já possui todos os dispositivos de hardware desenvolvidos, foram utilizados um nó MTD e outro MLT.

- NodeBuilder (Software de desenvolvimento em NeuronC) (ECHELON CORPORATION, 2003b; 1995a; 1995b):

A ferramenta NodeBuilder é um sistema de desenvolvimento que 
permite elaborar e depurar as aplicações para os nós, escritas na linguagem NeuronC. Por possuir recursos de depuração, essa ferramenta foi importante no desenvolvimento e realização de testes na rede.

Quando se refere à plataforma NodeBuilder, além do software para programação em NeuronC, com compilador e interface de desenvolvimento, também está incluso um dispositivo emulador do processador NeuronChip, com grande capacidade de memória para que se possa realizar a depuração do código durante a sua execução.

- LonMaker (ECHELON CORPORATION, 2003a):

Essa ferramenta foi importante para se criar uma rede inicial com as configurações de endereços lógicos e possíveis bindings. Ela possui uma interconectividade com o sistema NodeBuilder, agilizando todo o processo de programação, gravação da aplicação no nó da rede, depuração de código através da rede e comissionamento dos dispositivos.

-Analisador de Redes LonWorks ${ }^{\circledR}$ :

Esse analisador foi importante para a verificação das mensagens trocadas entre os nós da rede, permitindo detectar possíveis erros de protocolo ou de implementação.

Também foi importante para realizar uma análise quantitativa da solução apresentada, como o tráfego de informações na rede, tempo de conexão entre os dispositivos etc.

- Cabeamento para montagem de uma Rede LonWorks ${ }^{\circledR}$ :

Foi utilizado um cabeamento cat5e, o mesmo utilizado em redes TCP/IP, na topologia barramento. Esse cabo é padronizado pela LonMark e aprovado para ambientes de automação predial (ECHELON CORPORATION, 2001).

- Terminadores de rede LonWorks ${ }^{\circledR}$ :

Para realizar o correto balanceamento da rede LonWorks $^{\circledR}$, 
minimizando os erros na transmissão de mensagens, foram utilizados dois terminadores específicos para topologia barramento e para o transceiver TP/FT-10, utilizado pelos dispositivos desenvolvidos para o SDCTP. Eles foram dispostos um em cada extremidade do barramento, conforme especificado pela Echelon (ECHELON CORPORATION, 2001).

- Interface de Rede LonWorks ${ }^{\circledR}$ (ECHELON CORPORATION, 2003a):

Esta interface é necessária para permitir que o computador contendo todas as ferramentas de desenvolvimento citadas, possa interagir diretamente com os dispositivos de uma rede LonWorks ${ }^{\circledR}$, possibilitando alterações e depuração dos programas dos nós e análise da troca de mensagens entre dispositivos.

- Computador de desenvolvimento:

Este computador deverá possuir todas as ferramentas citadas para o desenvolvimento e validação do projeto proposto, além de uma interface para a sua conexão com a rede LonWorks ${ }^{\circledR}$.

A Figura 32 apresenta como foram dispostos e conectados os dispositivos citados acima.

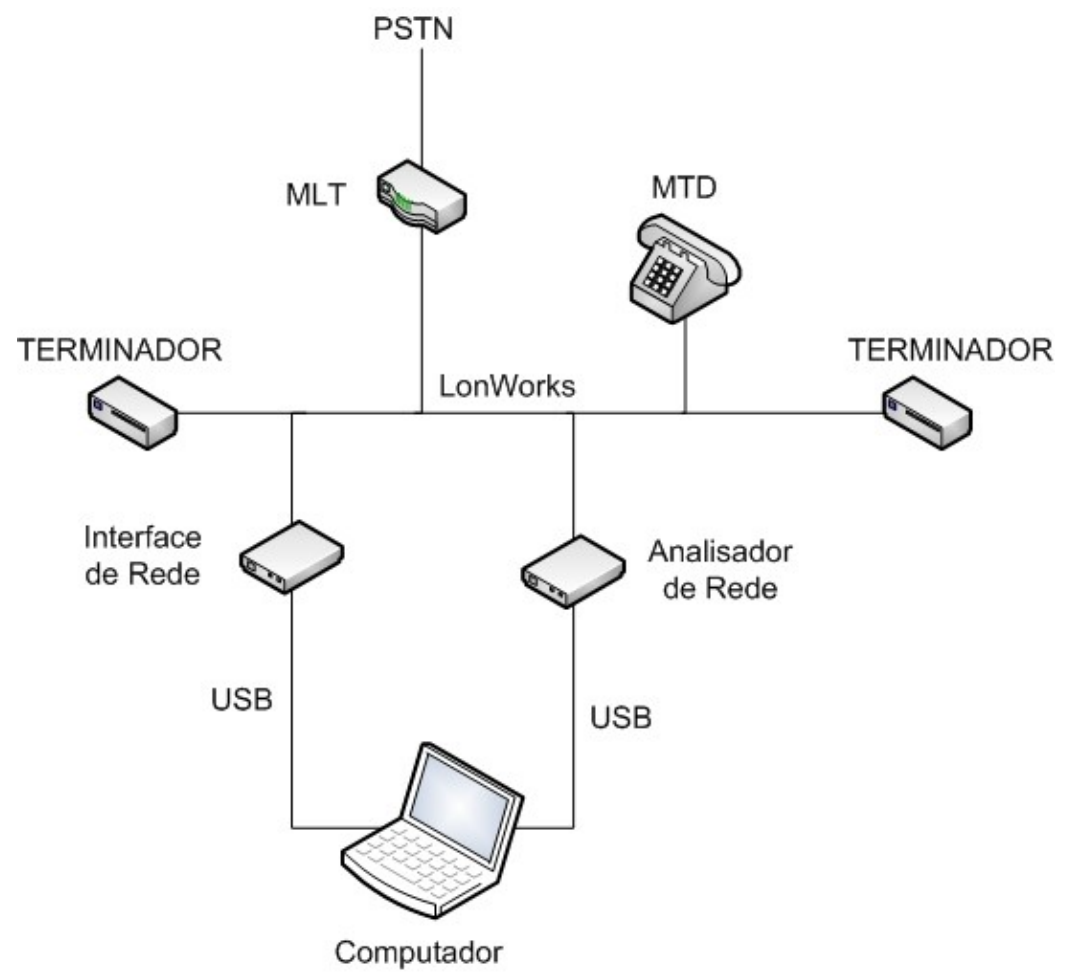

Figura 32 - Ligação física dos equipamentos 


\subsection{DESENVOLVIMENTO}

\subsubsection{Problema a ser solucionado}

Como apresentado na motivação deste trabalho, o problema principal a ser solucionado é o de permitir que dois dispositivos do sistema SDCTP possam interagir entre si trocando mensagens de voz e controle de telefonia, também chamado de controle de chamada (callprogress).

Mais especificamente, deve ser desenvolvido um método, utilizando a tecnologia LonWorks ${ }^{\circledR}$, para fazer dois dispositivos, que antes não tinham bindings configurados, interagirem entre si.

Para tal deve-se observar alguns requisitos a serem suplantados:

- Não inserir overhead significativo de comunicação no protocolo LonTalk

Como se tem uma banda limitada para a passagem de mensagens de voz (inicialmente a banda máxima será de $78 \mathrm{kbps}$ ), deve ser evitado utilizar outros protocolos encapsulados no protocolo LonTalk durante a troca de mensagens de voz.

A finalidade principal desse requisito é reduzir a banda total utilizada para a troca de mensagens de voz.

- Utilizar o menor número possível de entradas na tabela de endereços

Como a tabela de endereços no NeuronChip é limitada a apenas quinze entradas, deve-se utilizar o menor número possível de entradas nessa tabela para a troca de mensagens, uma vez que futuramente existirão outras aplicações que também deverão utiliza-las.

- Limitar o tempo de configuração para troca de mensagens de enlace

Para evitar um longo período de espera do usuário, todo o processo de configuração do dispositivo até o início da transmissão de fala deverá levar no máximo um segundo.

Esse período foi estipulado com base no tempo que o usuário chamador deverá esperar até que 0 atendente ouça o primeiro toque da sua chamada. Deseja-se que esse tempo seja no máximo quatro segundos, que 
corresponde à um período inteiro entre dois tons de chamada utilizado na telefonia fixa (AGÊNCIA NACIONAL DE TELECOMUNICAÇÕES, 2004). Com isso, o usuário chamador poderia ser atendido após ouvir o segundo tom de chamando através do monofone.

Como antes que o MLT realize o processo de binding ainda existem outros processos a serem feitos para a decisão de qual MTD irá atender ao MLT e espera-se que esses processos envolvam a troca de mensagens entre mais do que dois dispositivos de rede, e portanto sejam mais dispendiosos em termos de tempo, estipulou-se que o processo de binding automático deva levar no máximo um quarto do tempo total do processo de atendimento, portando, um segundo.

- Prescindir de atuação humana

Após os dispositivos estarem totalmente configurados para operação, todo tratamento de ligações, transferência de chamadas e troca de mensagens entre os dispositivos deve ser realizado sem qualquer intervenção humana.

- Autonomia dos dispositivos

Não deve haver nenhuma interdependência entre dispositivos para a realização de suas configurações de rede e de bindings, ou seja, cada dispositivo deve ser capaz de programar-se sem a atitude de outros dispositivos.

Esse requisito é importante para garantir a integridade do sistema a todo o momento, de forma que se algum dispositivo deixar de funcionar, o restante ainda é capaz de se configurar e continuar funcionando sem ele. Caso haja um centralizador que realize as configurações nos demais dispositivos, como é o caso de utilizar uma ferramenta de gerenciamento, e esse centralizador deixe de funcionar, o SDCTP inteiro também deixará de funcionar, visto que nenhum enlace poderá ser realizado.

\subsubsection{Modelagem do problema}

Com a finalidade de desenvolver uma solução que contemple todos os requisitos especificados, focou-se um cenário único que abrange as atitudes 
necessárias que o processo deve englobar, de forma que posteriormente ele possa ser utilizado em outros cenários que venham a surgir.

O cenário escolhido engloba o recebimento de uma chamada externa, a sua transferência para o ramal atendente e depois a finalização da chamada. Esse é um processo comum em qualquer equipamento PABX e possui todas as funcionalidades necessárias para que o processo de binding possa ser desenvolvido.

A Figura 33 apresenta um diagrama de seqüência do problema a ser solucionado ${ }^{4}$ 


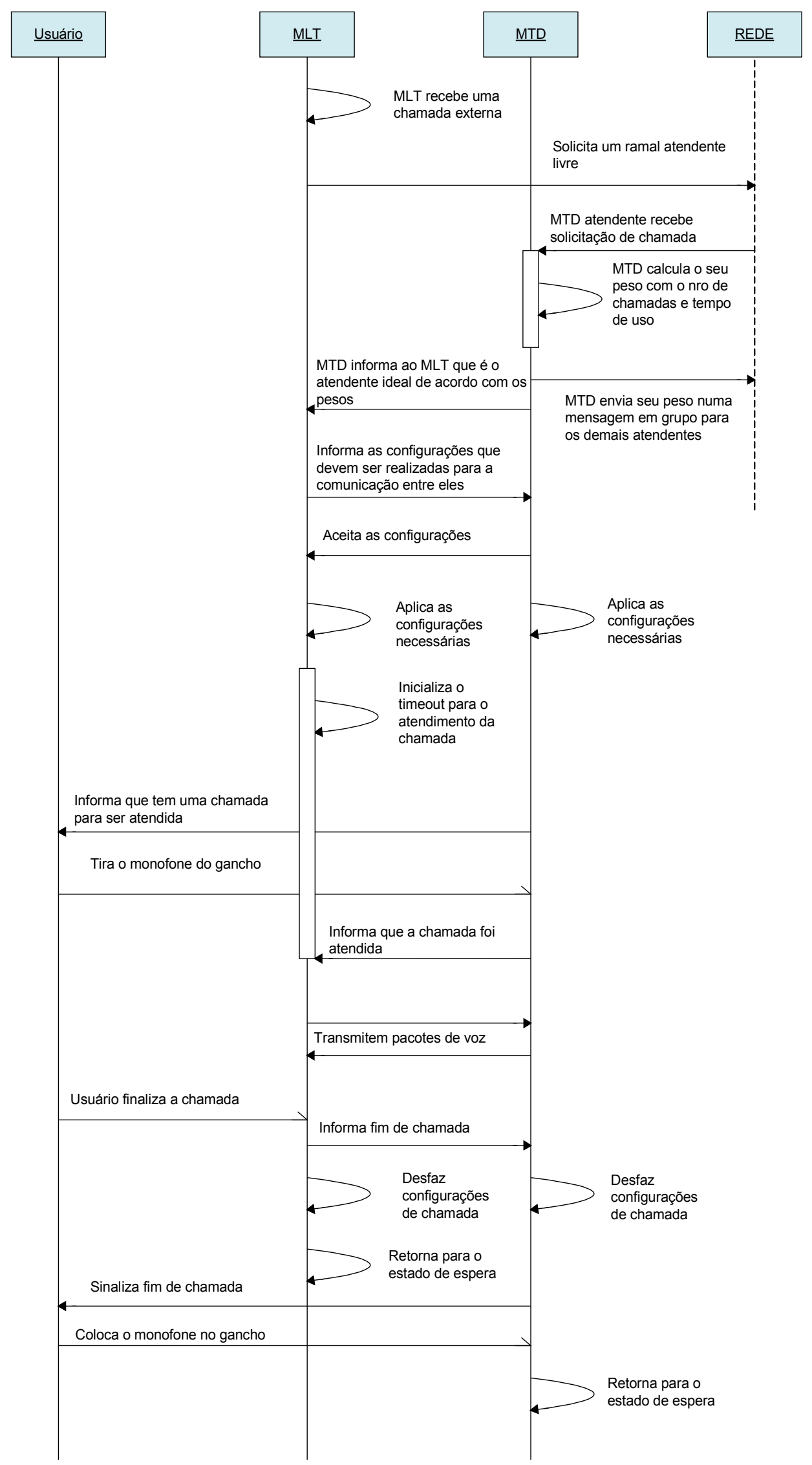

Figura 33 - Diagrama de seqüência do problema a ser solucionado 
Inicialmente o MLT e o MTD se encontram configurados na rede de controle e em estado de espera.

A partir de então, o MLT recebe uma chamada através da linha tronco e deverá, neste momento, solicitar algum ramal atendente livre para atender a chamada entrante.

Os MTDs, configurados como ramal atendente, deverão verificar entre eles, através de algum procedimento de decisão, qual irá receber essa chamada, devendo então, responder ao MLT que está disponível. Nesse trabalho assumiu-se que somente existe um MTD configurado como ramal atendente e o processo de decisão não será abordado por envolver processos de troca de mensagens e não de configuração de dispositivos.

Ao receber a resposta do MTD, o MLT deverá então, enviar a solicitação de que sejam realizadas a configurações necessárias entre eles para que a troca de mensagens de voz e controle de chamada seja possível. Neste ponto eles também deverão trocar mensagens para definirem características mais específicas relacionadas ao binding que será realizado, como por exemplo, o seletor que será utilizado.

Após terem sido realizadas as configurações necessárias e os bindings terem sido finalizados, o MTD deverá emitir o tom de chamada até que o usuário atenda ou o número de toques exceda um valor máximo.

Quando o usuário tirar o monofone do telefone do gancho, a transmissão dos pacotes de voz deverá ser iniciada e permanecerá até que um dos usuários recoloque o monofone no gancho.

Se o usuário que originou a chamada colocar o monofone no gancho, deverá ser considerado o fim da chamada. Já no caso do usuário atendente colocar o monofone no gancho, será considerado que a chamada deve permanecer em espera. Neste trabalho, em específico, somente será tratado o fim de chamada, uma vez que neste caso deve-se desfazer os bindings.

Concluindo, o cenário que será utilizado para o desenvolvimento do processo de binding automático engloba a recepção de uma chamada pelo MLT, a sua transmissão para o MTD atendente e a finalização da chamada.

Como o foco deste projeto está na configuração dos bindings e não 
no processo de recebimento de chamadas, não será resolvida nenhuma exceção que possa vir a ocorrer, apenas o processo padrão.

\subsubsection{Modelo da solução}

Antes de apresentar o modelo da solução é interessante observar mais profundamente como funcionam e quais as interfaces apresentadas pelos dispositivos envolvidos no problema, ou seja, o MLT e o MTD.

Tanto o MLT quanto o MTD possuem duas variáveis e duas mensagens de rede, sendo uma variável e uma mensagem de saída e uma variável e uma mensagem de entrada: nvoCallProgress, Voz, nviCallProgress, msg_in ${ }^{5}$, respectivamente. As mensagens são formadas por um vetor com o tamanho máximo de 228 bytes. As variáveis são formadas pelo tipo padronizado pela LonMark, snvt_telecom, sendo uma estrutura de dados com um byte de comprimento.

Através da msg_in, os dispositivos são capazes de receber mensagens implícitas de outros dispositivos, como por exemplo, mensagens contendo pacotes de voz. Através da mensagem de saída Voz eles são capazes de enviar mensagens contendo os dados de voz para outros dispositivos. Não será abordado qual o tamanho ideal para a passagem de dados de voz na rede pois isso não se enquadra no escopo deste trabalho.

Através da nvCallProgress os dispositivos enviam e recebem informações a respeito do andamento da chamada entre eles, ou seja, através dela é realizado o controle da chamada.

A Figura 34 apresenta a interface dos dois dispositivos no LonMaker.
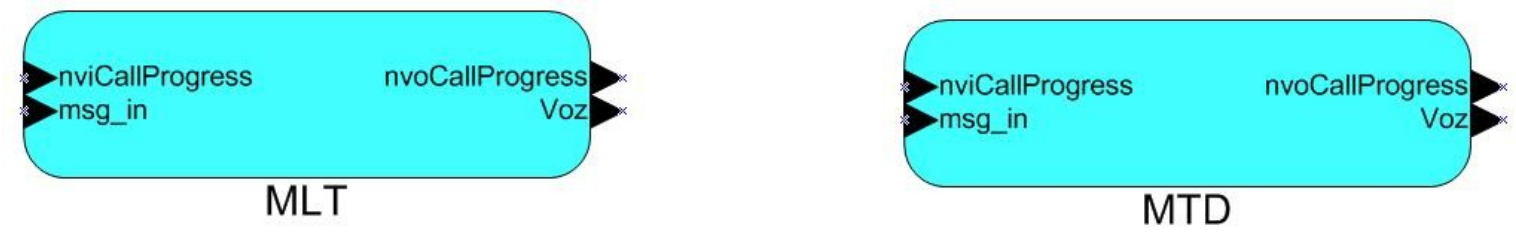

Figura 34 - Interface de rede do MLT e do MTD

Para que um enlace telefônico possa ser realizado, as variáveis de saída do MTD devem ser conectadas com as variáveis de entrada do MLT e viceversa.

5 Como nomenclatura padrão, adota-se que as variáveis contendo no nome o prefixo nvo são variáveis de saída e aquelas contendo nvi como prefixo do nome são variáveis de entrada. 
Com essa conexão realizada, é possível que os dispositivos troquem informações e dados de voz com o menor overhead possível de protocolo na tecnologia LonWorks ${ }^{\circledR}$, uma vez que não é inserido nenhuma informação adicional na mensagem para servir de cabeçalho para a aplicação, são transmitidos apenas os cabeçalhos de transmissão padrão ao protocolo LonTalk e os dados de voz.

No entanto, ao ser realizado o binding alguns parâmetros para ajuste das tabelas dos dispositivos devem ser acordados entre eles. O principal deles é o seletor que será utilizado.

A Figura 35 mostra um exemplo, gerado com o LonMaker, de como essas tabelas ficam configuradas após essa negociação:

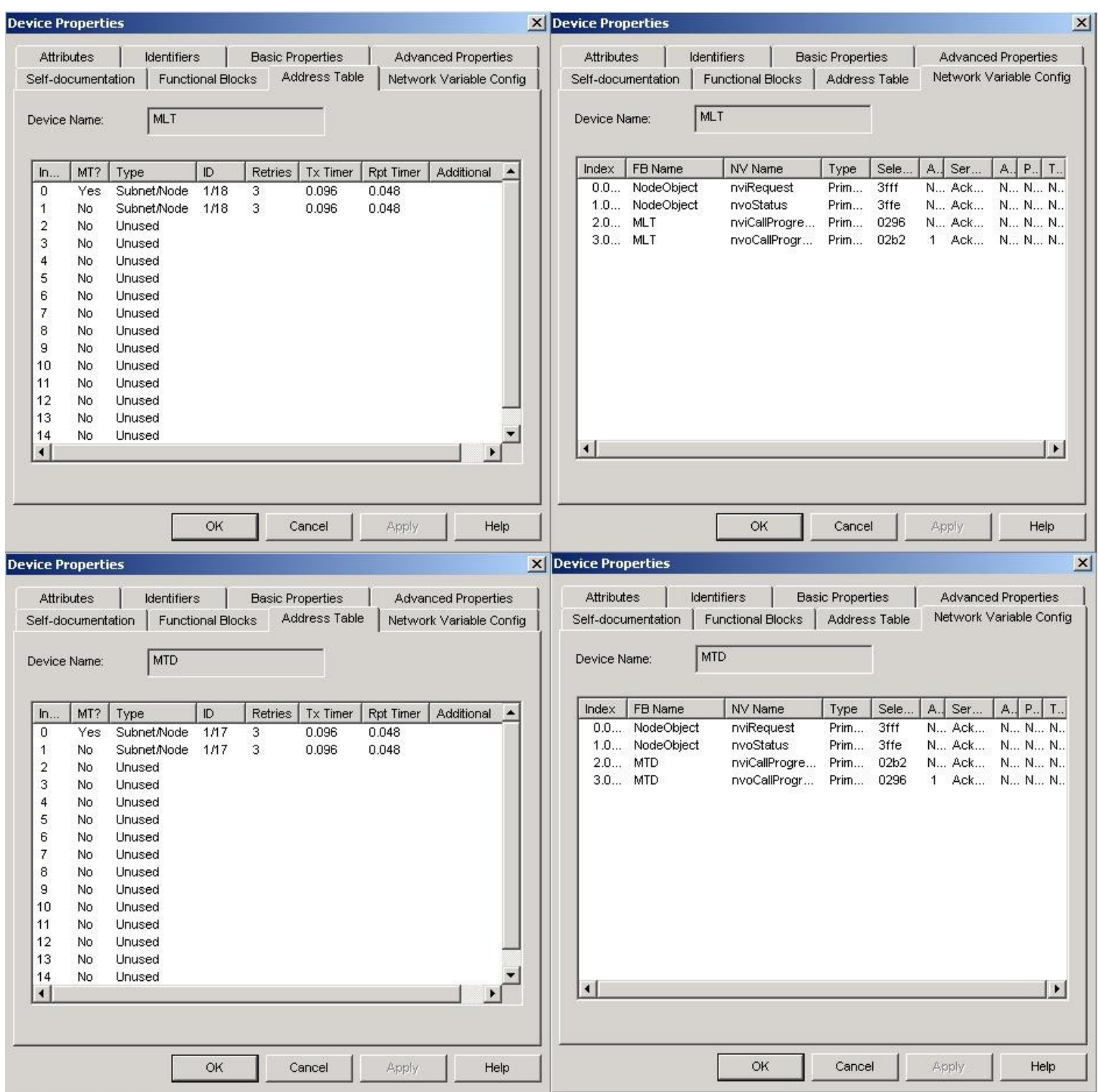

Figura 35 - Possíveis tabelas após o binding entre o MLT e MTD 
Esses valores podem ser conhecidos e ajustados por cada dispositivo individualmente e, portanto não são necessárias trocas de mensagens para que eles saibam que valores utilizar.

Assim, as informações que necessariamente devem ser transferidas através da interação entre os dispositivos são: Type e ID da Tabela de Endereços; Selector da Tabela de Configuração de Variáveis de Rede.

O Type e o ID podem ser identificados através das próprias mensagens de rede, sem que eles venham como dados de mensagens. Já o Selector deve ser definido e acordado a cada binding realizado, conforme já discutido anteriormente.

Por fim, a informação no campo Address da Tabela de Configuração de Variáveis de Rede deve ser definido por cada dispositivo, conforme a disponibilidade da Tabela de Endereços, ou seja, não há a necessidade de um dispositivo informar ao outro qual valor está utilizando.

Cabe destacar que a mensagem de saída Voz e de entrada msg_in não possuem entradas na Tabela de Configurações de Variáveis de Rede, pois são na verdade mensagens diretas para os dispositivos e não propriamente variáveis.

Apesar disso, pode ser realizado o binding entre elas e, da mesma forma que no caso das variáveis de rede, será consumida uma entrada da Tabela de Endereços.

Outro ponto importante a se levantar, são os tipos de mensagens que podem ser trocadas na rede utilizando o protocolo LonTalk. O primeiro tipo, é chamado de mensagens implícitas e o segundo de mensagens explícitas.

As mensagens implícitas são enviadas com base nas configurações da Tabelas de Variáveis de Rede e da tabela Endereços, e todo o processamento referente ao seu tratamento e transmissão, como o controle de seqüência, retransmissões etc, é realizado paralelamente por dois processadores do NeuronChip, cabendo ao terceiro processador apenas o tratamento de dados.

As mensagens explícitas podem ser transmitidas para qualquer dispositivo, independente das tabelas e configurações de bindings, porém todo o tratamento que antes era realizado pelos dois processadores de rede deve ser realizado pelo processador de aplicação e programado pelo usuário. 
Portanto é necessário balancear a utilização dessas duas categorias de mensagens, de forma que não se sobrecarregue o processador de aplicação com tarefas que podem ser realizadas pelos processadores de rede. Isso pode ser feito utilizando as mensagens explícitas apenas nos momentos de troca de informações antes de realizar os bindings utilizando assim uma capacidade de processamento que estará disponível no momento e poupando a execução de processos complexos de configuração. Posteriormente, quando o enlace já tiver sido estabelecido, essa capacidade de processamento não estará disponível, o processador de aplicação estará sendo utilizado para o tratamento de mensagens de voz e controle de chamada, portanto, neste momento deve-se utilizar as mensagens implícitas.

Também se deve atentar para que não se altere em demasia as tabelas de rede e de configurações, visto que elas se encontram em área de EEPROM e a sua vida útil é diretamente ligada ao número de gravações realizadas além de ser um processo custoso em termos de tempo de acesso e processos de software, já que cada alteração implica no recálculo do checksum da configuração de rede.

Para facilitar a modelagem da solução, o problema foi dividido em três partes: a primeira delas compreende o handshake e decisão de qual seletor será utilizado; a segunda é a realização dos bindings propriamente ditos; a terceira etapa apenas será para desfazer os bindings realizados deixando os dispositivos livres para novas conexões.

\subsubsection{Primeira Etapa}

Como a primeira etapa envolve mais de um dispositivo, o MLT e o MTD, a Figura 36 apresenta um diagrama de seqüência detalhando o processo de handshake, já supondo a existência de apenas um ramal atendente já conhecido pelo MLT: 


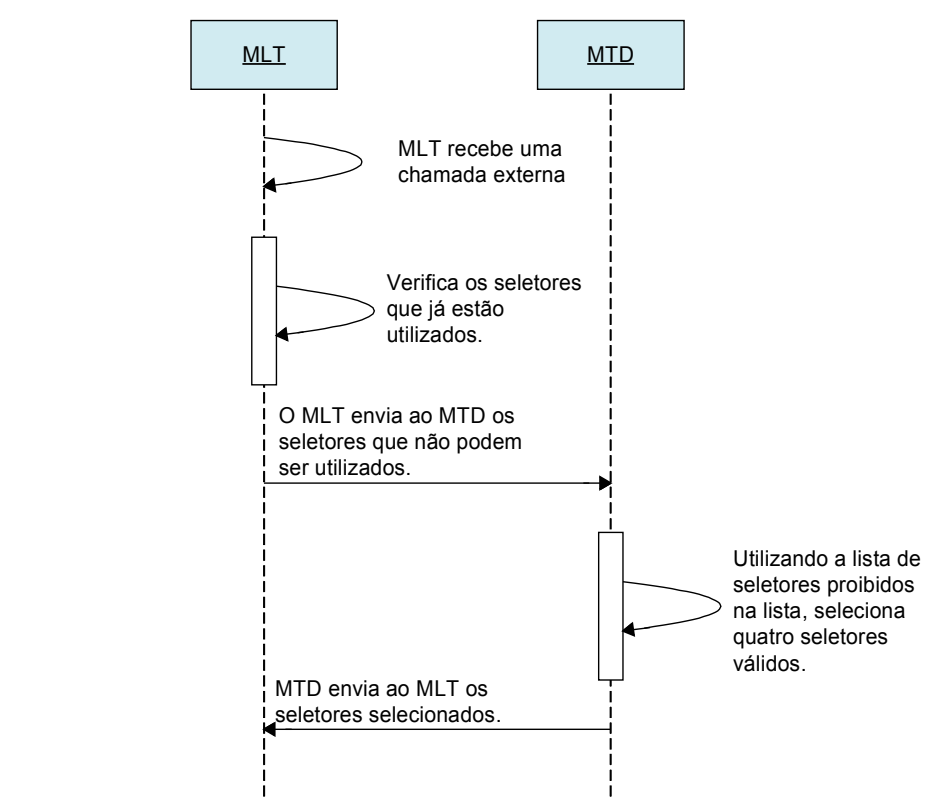

Figura 36 - Diagrama de seqüência do handshake entre MLT e MDT

O processo se inicia com o MLT recebendo uma chamada externa. Em seguida, ele deverá verificar junto à sua tabela de configuração de variáveis os seletores que já estão sendo utilizados em outras conexões e que, portanto não podem mais ser utilizados. Esse processo de verificação, consiste em varrer todas as entradas da Tabela de Configuração de Variáveis comparando os valores dos seletores utilizados por outras variáveis com os que se deseja utilizar, lembrando que valores acima de 0x2FFF significa que não existe binding com a variável.

Após o MLT levantar a lista de seletores proibidos, esta deverá ser enviada para o MTD que, por sua vez, será responsável por verificar junto à sua lista de configuração de variáveis dois seletores livres para a configuração dos bindings.

Uma mensagem explícita de saída tem a seguinte estrutura de dados (ECHELON CORPORATION, 1995a):

struct \{

boolean priority_on;

int code;

int data[MAXDATA];

boolean authenticated;

service_type service;

msg_out dest_addr;

\} msg_out; 
O significado de cada campo é:

- priority_on

Indica se a mensagem terá acesso prioritário à rede de controle em relação às outras variáveis. Por ser desnecessário, esse campo será utilizado com seu valor em zero (false).

\section{- Code}

Informa o tipo de mensagem que está sendo enviada. Por exemplo, se estiver sendo utilizada uma mensagem de gerenciamento de rede para a requisição do valor de uma variável, este campo deverá ser carregado com o valor $0 \times 73$, sendo que uma resposta válida à essa requisição tem em seu campo code o valor 0x33 e um resposta inválida o valor 0x13 (MOTOROLA, 1997).

A tecnologia LonWorks ${ }^{\circledR}$ define que qualquer valor entre $0 \times 00$ e $0 \times 3 E$ está livre para ser utilizado em qualquer aplicação. Escolheu-se o valor 0x00 para indicar o envio de seletores proibidos e 0x01 para indicar o envio dos seletores escolhidos.

\section{- data[MAXDATA]}

Contém todos os dados a serem trocados entre dispositivos. $\mathrm{Na}$ mensagem do MLT para o MTD, os seletores que não podem ser utilizados poderão ser dispostos em qualquer ordem, sendo que este campo em vazio indica que não há restrição de valores.

Foram necessários dois seletores, pois realizou-se as seguintes conexões: nvoCallProgress do MLT com a nviCallProgress do MTD; nvoCallProgress do MTD com a nviCallProgress do MLT, e foram enviados no campo de dados na respectiva ordem apresentada.

Como as conexões Voz do MLT com msg_in do MTD; e Voz do MTD com msg_in do MLT são na verdade conexões entre mensagens e não variáveis de rede, não é necessário o uso de seletores.

- Authenticated

Indica se a variável precisa ser autenticada para poder ser recebida 
pelo nó de destino. Como não foi utilizado, o valor será sempre zero (false).

- Service

Indica que tipo de serviço utilizado para a troca de mensagens entre os dispositivos. Utilizou-se o serviço de Request/Response, sendo o seu valor carregado com a definição REQUEST.

Esse serviço foi escolhido, pois além de garantir a entrega fim-a-fim da mensagem, diminui o tráfego de informações na rede, faz com que a resposta do MTD funcione como verificação de entrega da mensagem do MLT.

Poder-se-ía utilizar o tipo de mensagem com o serviço de reconhecimento das mensagens enviadas através de uma resposta ack: para tanto, seriam necessárias quatro mensagens de rede para realizar o handshake. Utilizando o serviço de request/response são necessárias apenas duas.

- dest_addr

Contém o endereço de destino para onde será enviada a mensagem. No caso do MLT ele será preenchido com o endereço do MTD e no caso do MTD ele conterá o endereço do MLT.

No processo completo de atendimento no SDCTP existe uma etapa antes da troca dos valores dos seletores que é responsável por permitir ao MLT achar o endereço do MTD responsável por atender à essa chamada, porém ele não será abordado nesse trabalho e é assumido que esse endereço já é conhecido.

Após receber a lista de seletores proibidos, o MTD deverá uni-la a uma lista de seletores que já está sendo utilizada por algumas de suas variáveis internas e selecionar dois seletores válidos.

Essa lista deverá ser enviada para o MLT e após o seu envio o MTD deverá iniciar o processo de configuração dos bindings com o MLT. Da mesma forma, ao receber essa mensagem, o MLT deverá iniciar o processo de binding com o MTD, dando início à segunda etapa do processo.

\subsubsection{Segunda Etapa}

A segunda etapa desse processo é igual para ambos os dispositivos, 
pois os mesmos parâmetros e variáveis devem ser configurados. A Figura 37 apresenta o diagrama de fluxo de dados para a solução desenvolvida.

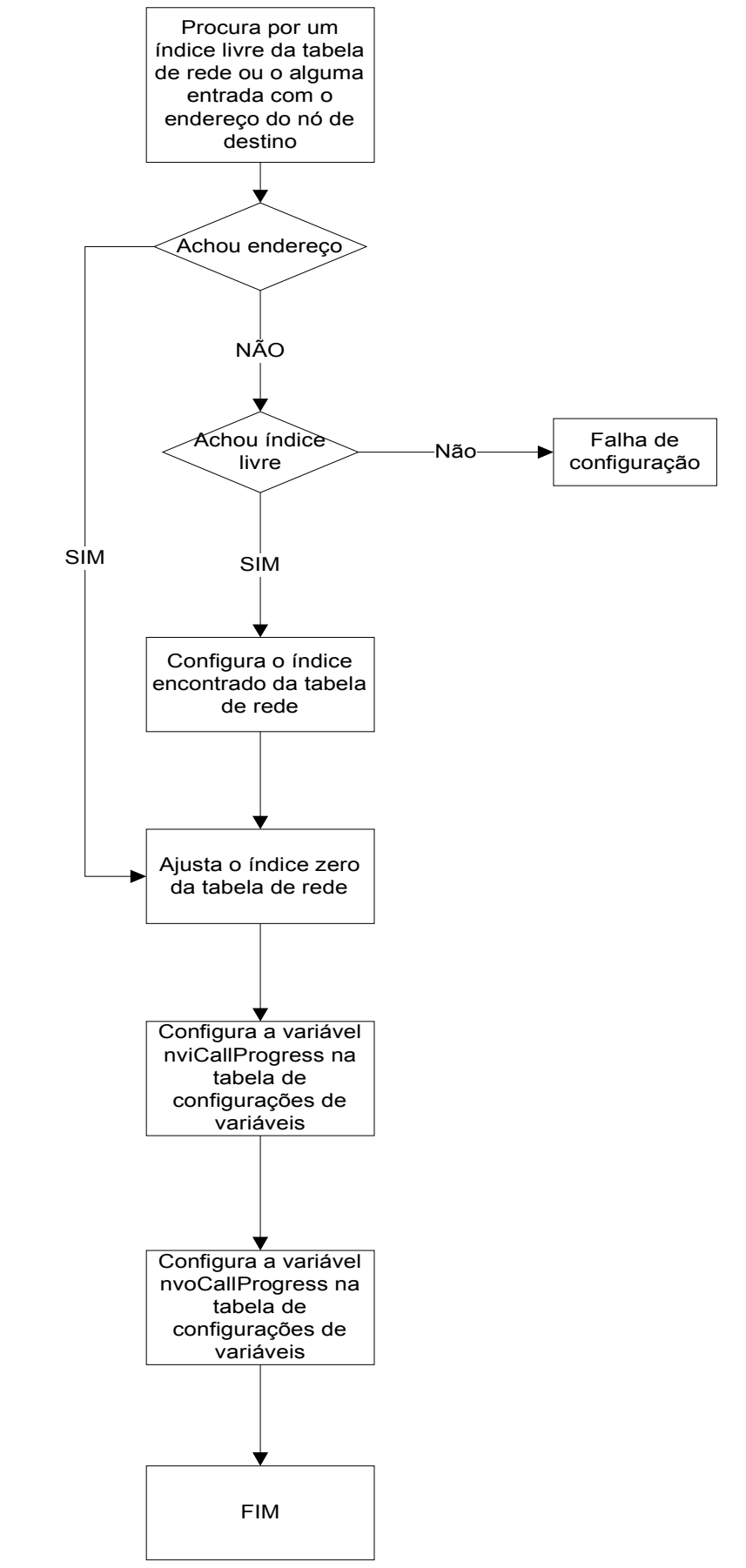

Figura 37 - Fluxo de configuração dos bindings realizados

Para que seja possível realizar os bindings entre os dispositivos, o endereço de destino do nó que receberá a variável de rede nvoCallProgress já deve existir na Tabela de Rede ou deve haver algum índice vago para que esse endereço 
seja programado.

Caso já exista essa entrada na tabela, o índice na qual ela foi encontrada deve ser copiado, para posteriormente ser configurado na tabela de configurações de variáveis. Caso contrário, será utilizado um índice vago para se realizar essa configuração na tabela de rede.

O índice zero é reservado para o binding entre mensagens de rede, quando existir alguma mensagem configurada na aplicação do dispositivo. Como ambos possuem a mensagem Voz, esse índice não pode ser utilizado por variáveis de rede.

Como o tamanho máximo da tabela é 15, ou seja, os índices vão de zero a 14, qualquer valor superior ou igual a 15 significa que não há espaço vago para mais uma conexão. Neste caso, se a entrada com o endereço do nó de destino não existir, não será possível realizar o binding e o processo deve ser cancelado.

Após a configuração da Tabela de Rede, pode ser realizada a configuração da Tabela de Variáveis. Neste passo, serão configuradas nas respectivas variáveis, o índice da Tabela de Rede que eles devem utilizar, se necessário, e por fim, o seletor.

Ao fim desse processo, o binding foi realizado com sucesso e o MLT pode dar início ao controle de chamada enviando através da nvoCallProgress a indicação de chamada. O MTD, por sua vez, ao receber o comando de chamando deverá informar ao MLT que o está executando e tocar a campainha do telefone para o usuário saber que há uma chamada.

\subsubsection{Terceira Etapa}

Essa última etapa do processo tem início após o envio do comando de telefone no gancho pelo MLT através da variável nvoCallProgress. Ao seu fim, ambos os dispositivos devem estar livres para receberem novas chamadas.

A Figura 38 apresenta o diagrama de fluxo de dados do processo a ser realizado: 


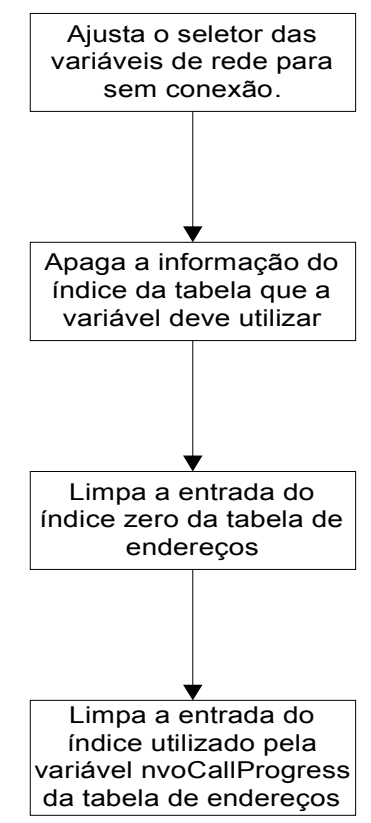

Figura 38 - Diagrama de fluxo de dados para desfazer os bindings

Como se observa, todos os processos reconfiguram as tabelas conforme os padrões da tecnologia LonWorks ${ }^{\circledR}$ para indicar que não existe conexão ou que o endereço está válido para novas conexões.

Portanto esse processo não exige a troca de mensagens entre os dispositivos e pode ser realizado de forma individual.

\subsubsection{Agente do Dispositivo}

Como se pode notar, todas as etapas acima são necessárias para realizar e desfazer os bindings entre dispositivos, não exercendo nenhuma influência no algoritmo de controle que o mesmo deve desempenhar.

Essa observação é reforçada pelo fato de que atualmente existem ferramentas externas para essas operações, ou seja, configurar o dispositivo na rede. Enquanto isso, o algoritmo de controle interno do nó de rede continua a funcionar durante a utilização dessas ferramentas e independente da sua configuração de rede.

Assim, as três etapas do processo de autoconfiguração poderão ser realizadas por um novo programa, neste caso um agente, sendo executado de forma paralela e independente de todas as aplicações de controle e automação do dispositivo.

No caso dos dispositivos de rede LonWorks, esse agente deverá ser 
executado na camada de aplicação do NeuronChip e terá o controle de todas as tabelas de configuração interna do nó. Isso fará com que ele tenha acesso à todas as informações necessárias para o comissionamento e realização de bindings do dispositivo, como as variáveis de redes, perfis funcionais etc.

Abaixo segue uma figura exemplificando a adição do agente a um perfil funcional:

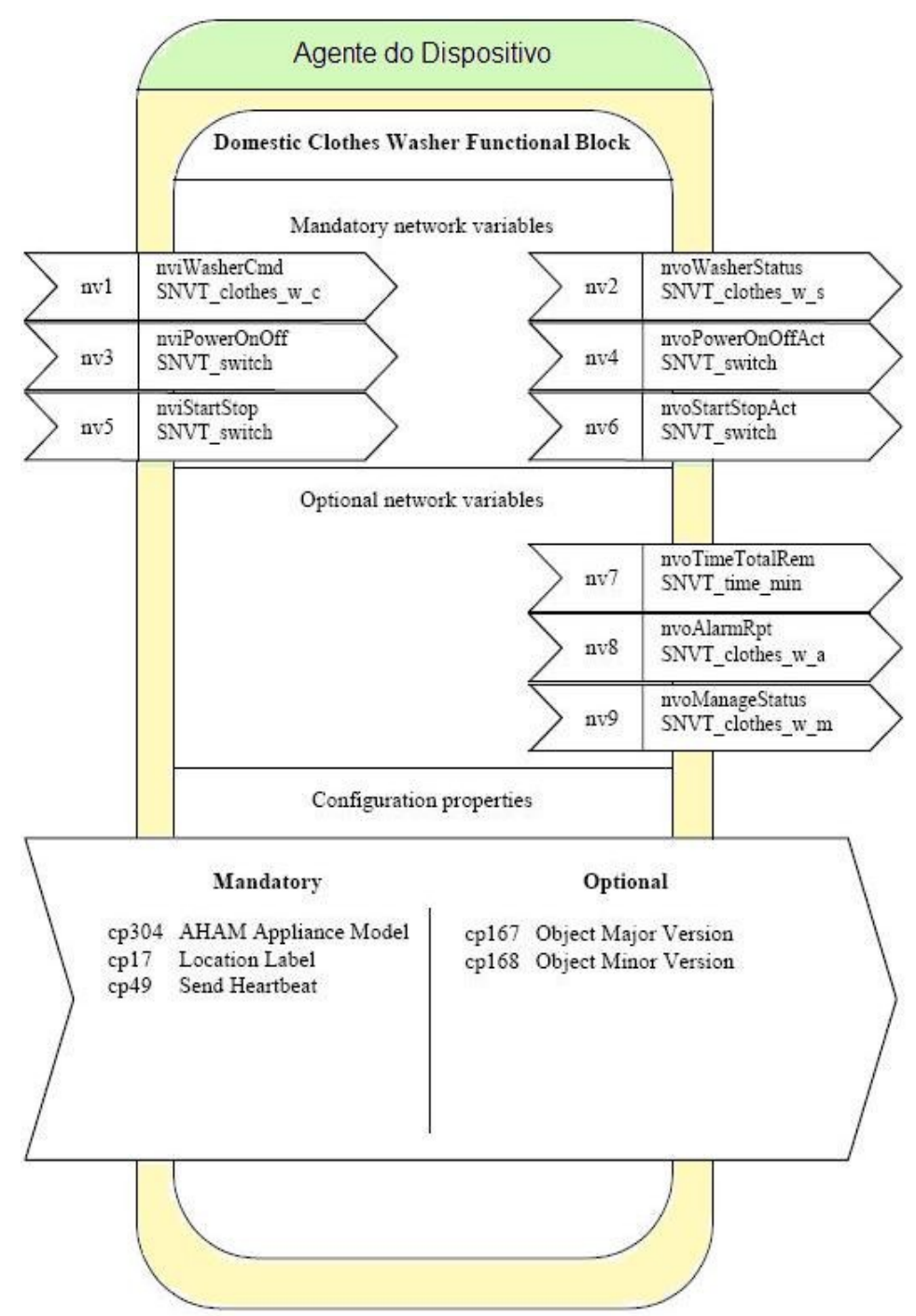

Figura 39: Exemplo do agente como uma camada extra no perfil funcional

Como se pode observar na figura 39 , o agente será modelado como uma camada extra de software que engloba um ou mais perfis funcionais, responsável apenas por realizar a configuração das variáveis de rede e de configuração do dispositivo da rede. 
As aplicações atreladas a cada um dos perfis funcionais não serão alteradas nem sofrerão interferência no seu funcionamento devido à alguma atuação do agente configurador.

\subsubsection{Análise dos Resultados e Discussão}

\subsubsection{Primeira Etapa}

Como forma de resolver a primeira etapa, que contempla a definição dos seletores, foi utilizada a estrutura de envio de mensagens explícitas entre o MLT e o MTD através do serviço do tipo request/response.

Foi desenvolvido um procedimento responsável por varrer a Tabela de Configuração de Variáveis e elaborar uma lista de todas aquelas que estão sendo utilizadas. Após essa seleção, a mensagem de início ao handshake é enviada.

Recebida pelo MTD a mensagem é tratada e devolvida através de uma resposta para o MLT contendo a definição dos seletores a serem usados. A Figura 40 apresenta a cópia da tela do analisador de protocolos com destaque nas mensagens trocadas: 


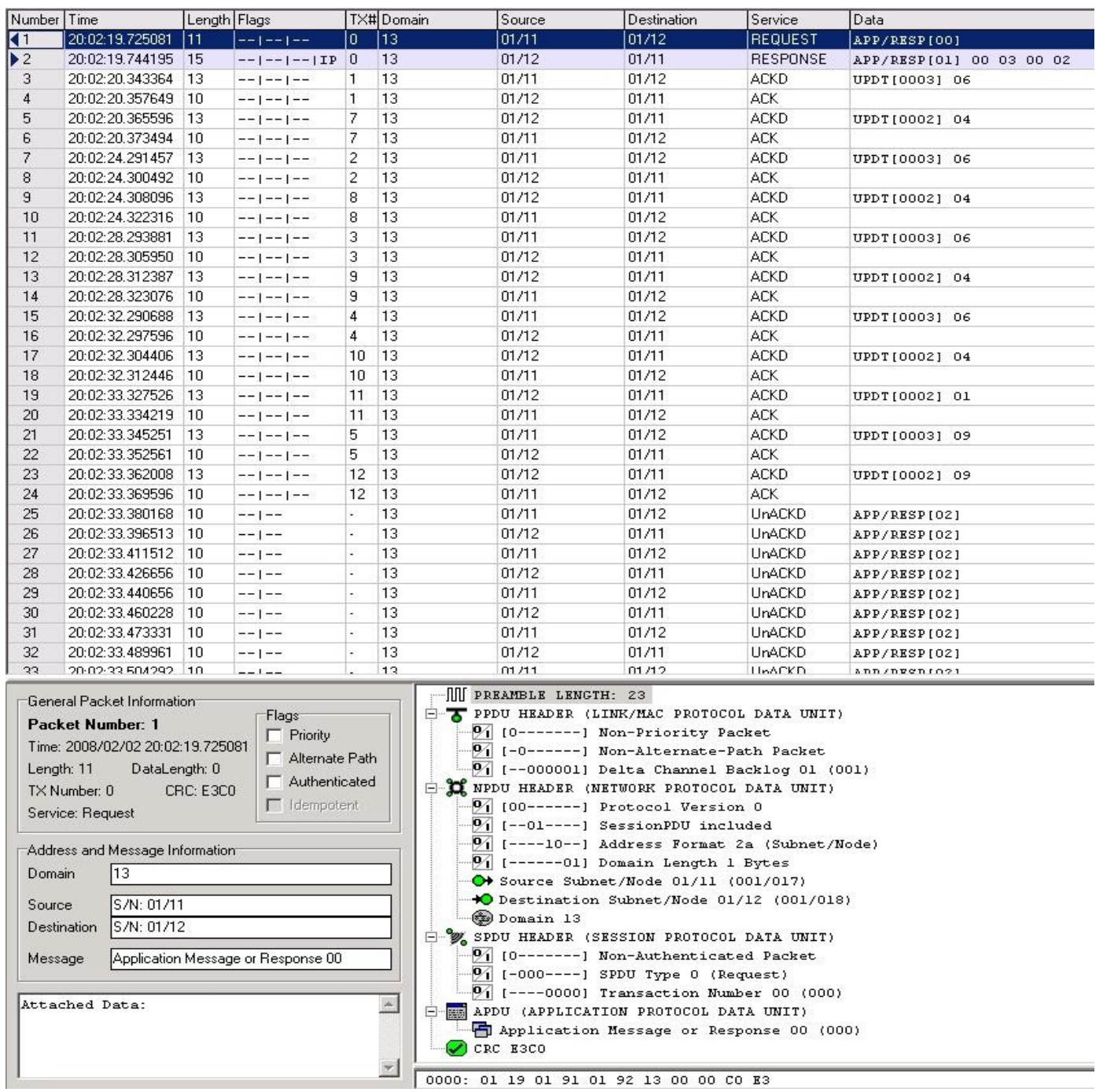

Figura 40 - Troca de mensagens de handshake entre MLT e MTD

Observa-se na tabela que a primeira mensagem, marcada em azul escuro, é o início do handshake, ou seja, vai do MLT ao MTD. Neste caso, o MLT é o nó 0x11, da subrede 0x01 e do domínio 0x13; o MTD é o nó 0x12, da subrede 0x01 e domínio 0x13. Esses endereços podem ser observados nos campos origem (source), destino (destination) e domínio (domain).

Ainda através da tela do analisador de protocolos, pode-se observar o serviço utilizado por essa mensagem, no campo serviço (service), neste caso, request.

Logo em seguida, em azul claro, pode-se verificar a resposta dessa mensagem, sendo com o tipo de serviço response e com a origem no MTD e destino MLT. 
No campo dado (data) encontra-se a seqüência de valores 000300 02, que corresponde aos seletores que devem ser utilizados nos bindings. Com os dados nessa seqüência, significa que deverão ser utilizados os seletores dois e três. Isso ocorreu, pois os seletores zero e um já estavam em uso no momento em que foi realizada verificação de seletores livres pelo MTD.

Como se está empregando um serviço que garante a entrega de resposta pode-se observar, utilizando o analisador de protocolo, a retransmissão de mensagens que ocorre caso a resposta não chegue antes que estoure o timeout de retransmissão.

A Figura 41 apresenta a tela do analisador com um caso em que ocorreu a retransmissão de mensagens.

\begin{tabular}{|l|l|l|l|l|l|l|l|l|l|}
\hline Number & Time & Length & Flags & TX\# & Domain & Source & Destination & Service & Data \\
\hline $\mathbf{1 3 1 4}$ & $22: 44: 45.904000$ & 11 & $--\mid--1--$ & 7 & 13 & $01 / 11$ & $01 / 12$ & REQUEST & A.PP/RESP [00] \\
\hline 315 & $22: 44: 46.003667$ & 11 & $--\mid--1--$ & 7 & 13 & $01 / 11$ & $01 / 12$ & REQUEST & APP/RESP [00] \\
316 & $22: 44: 46.100939$ & 11 & - -IAP|-- & 7 & 13 & $01 / 11$ & $01 / 12$ & REQUEST & APP/RESP [00] \\
317 & $22: 44: 46.196984$ & 11 & - -IAP|-- & 7 & 13 & $01 / 11$ & $01 / 12$ & REQUEST & APP/RESP [00] \\
\hline
\end{tabular}

Figura 41 - Retransmissão de mensagem pelo MLT

Através do número do pacote, encontrado no campo TX\#, pode-se observar que realmente se trata de uma retransmissão, uma vez que todas as mensagens são idênticas, inclusive a sua numeração.

A única diferença entre elas é a informação no campo flags. O flag AP se destina ao caso de uma rede que contenha mais de um roteador, informando que a rota padrão falhou e que agora deve ser tentada uma rota diferente.

Caso após todas as retransmissões ainda não seja obtida nenhuma resposta, o MLT não irá atender a ligação, assumindo que não há ramal atendente ou ele se encontra fora de operação.

Uma característica importante para observar é o tempo em que se leva para a decisão dos seletores, uma vez que para isso existe um processo de varredura de tabelas internas, comparações e trocas de mensagens de rede. Esse tempo deverá ser contabilizado na contagem total do tempo que se leva para realizar os bindings.

A Tabela 1 apresenta os tempos medidos em dez processos idênticos que foram executados: 


\begin{tabular}{|c|c|c|}
\cline { 2 - 3 } \multicolumn{1}{c|}{} & Tempos Obtidos (ms) & Média (ms) \\
\hline $\mathbf{1}$ & 18,326 & 22,501 \\
\hline $\mathbf{2}$ & 23,899 & Desvio padrão (ms) \\
\hline $\mathbf{3}$ & 19,472 & 2,651 \\
\hline $\mathbf{4}$ & 25,346 & \\
\hline $\mathbf{5}$ & 22,881 & \\
\hline $\mathbf{6}$ & 23,793 & \\
\hline $\mathbf{7}$ & 21,907 & \\
\hline $\mathbf{8}$ & 26,603 & \\
\hline $\mathbf{9}$ & 19,790 & \\
\hline $\mathbf{1 0}$ & 22,994 & \\
\hline
\end{tabular}

Tabela 1 - Tempo médio de uma operação de decisão dos seletores

Portanto, o processo desenvolvido para a decisão dos seletores envolve apenas o envio de duas mensagens de rede e um tempo total de execução de 22,5 ms em média.

Caso o mesmo processo seja realizado por uma ferramenta de gerenciamento de rede, como o LonMaker, não é necessário que sejam varridas duas bases de dados separadas, apenas uma centralizada, e também não é necessário a troca de mensagens entre dispositivos, o que torna esse processo muito mais rápido em comparação ao desenvolvido.

\subsubsection{Segunda Etapa}

Com a resposta da primeira etapa, ou seja, os seletores corretamente definidos, agora é possível realizar todo o processo de binding entre os dispositivos.

Através da tabela do analisador de rede, observando a Figura 40, é possível verificar que logo após a resposta do MTD para o MLT com os seletores definidos, foram enviadas mensagens de variáveis de rede.

A primeira delas, abaixo da marcação em azul claro, vai do MLT para o MTD e contém no seu campo de dados o valor 0x06, que corresponde à sinalização de chamando. Ao receber essa mensagem, o MTD deverá emitir o tom de chamada no telefone.

Logo em seguida, é enviada a confirmação de recebimento da mensagem do MLT pelo MTD. O reconhecimento, na posição 5 , consiste em uma mensagem do MTD para o MLT com o valor 0x04 no campo dados, sendo na verdade uma informação do controle de chamada indicando ao MLT que o tom 
sonoro está tocando.

Essa seqüência de mensagens é refeita a cada quatro segundos e irá se repetir até que o usuário retire o monofone do gancho, sinalizando que a chamada foi atendida e deverá ser iniciada a troca de mensagens de voz, ou até um número limite de chamadas indicando que ninguém irá atender.

Ainda utilizando o analisador, é possível medir o tempo desde o fim do handshake até o início da troca de mensagens de controle da chamada. $\mathrm{Na}$ Figura 40, pode-se verificar que a resposta do MTD contendo os seletores foi enviada às 20:02:19.744195 e a primeira mensagem de controle de chamada foi transmitida às 20:02:20.343364. Isso significa que desde o fim do handshake ao início da troca de mensagens passaram-se aproximadamente $600 \mathrm{~ms}$.

A Tabela 2 apresenta os tempos obtidos para dez operações idênticas, a média e seu desvio padrão.

\begin{tabular}{|c|c|c|}
\cline { 2 - 3 } \multicolumn{1}{c|}{} & Tempos Obtidos (ms) & Média (ms) \\
\hline $\mathbf{1}$ & 599,169 & 602,251 \\
\hline $\mathbf{2}$ & 620,920 & Desvio padrão (ms) \\
\hline $\mathbf{3}$ & 599,509 & 6,715 \\
\hline $\mathbf{4}$ & 602,336 & \\
\hline $\mathbf{5}$ & 599,007 & \\
\hline $\mathbf{6}$ & 599,600 & \\
\hline $\mathbf{7}$ & 601,642 & \\
\hline $\mathbf{8}$ & 601,344 & \\
\hline $\mathbf{9}$ & 601,269 & \\
\hline $\mathbf{1 0}$ & 597,714 & \\
\hline
\end{tabular}

Tabela 2 - Levantamento do tempo médio para a realização de todo o processo

Como forma de verificar a eficiência da solução em termos de tempo de execução do binding, o mesmo processo foi realizado utilizando o LonMaker, sendo os tempos obtidos apresentados na Tabela 3. 


\begin{tabular}{|c|c|c|}
\cline { 2 - 3 } \multicolumn{1}{c|}{} & Tempos Obtidos (ms) & Média (ms) \\
\hline $\mathbf{1}$ & 2173,838 & 1983,964 \\
\hline $\mathbf{2}$ & 2195,800 & Desvio padrão (ms) \\
\hline $\mathbf{3}$ & 2157,312 & 349,153 \\
\hline $\mathbf{4}$ & 1519,212 & \\
\hline $\mathbf{5}$ & 2254,034 & \\
\hline $\mathbf{6}$ & 2130,467 & \\
\hline $\mathbf{7}$ & 1735,848 & \\
\hline $\mathbf{8}$ & 1264,957 & \\
\hline $\mathbf{9}$ & 2190,707 & \\
\hline $\mathbf{1 0}$ & 2217,469 & \\
\hline
\end{tabular}

Tabela 3 - Levantamento do processo de binding utilizando o LonMaker

Comparando-se a média dos tempos entre os dois processos, podese verificar que quando o binding é realizado pelo próprio dispositivo, ele é cerca de quatro vezes mais rápido do que quando é realizado por um dispositivo externo.

Isso ocorre uma vez que quando o binding é realizado em um nó através de outro, deve-se utilizar mensagens de rede de gerenciamento e realizar uma quantidade de verificações e modificações no estado de funcionamento no nó em processo de configuração, que não são necessários quando as tabelas são escritas pelo próprio nó através de métodos internos.

Certamente a troca de mensagens de gerenciamento da ligação através da variável CallProgress comprova que o binding entre dispositivos foi realizado de forma completa e correta, porém ainda pode-se observar as tabelas dos dispositivos e compará-las com as geradas por uma ferramenta de gerenciamento de rede, conforme apresentado na Figura 35.

A Figura 42 apresenta as tabelas geradas em um processo de autoconfiguração. 


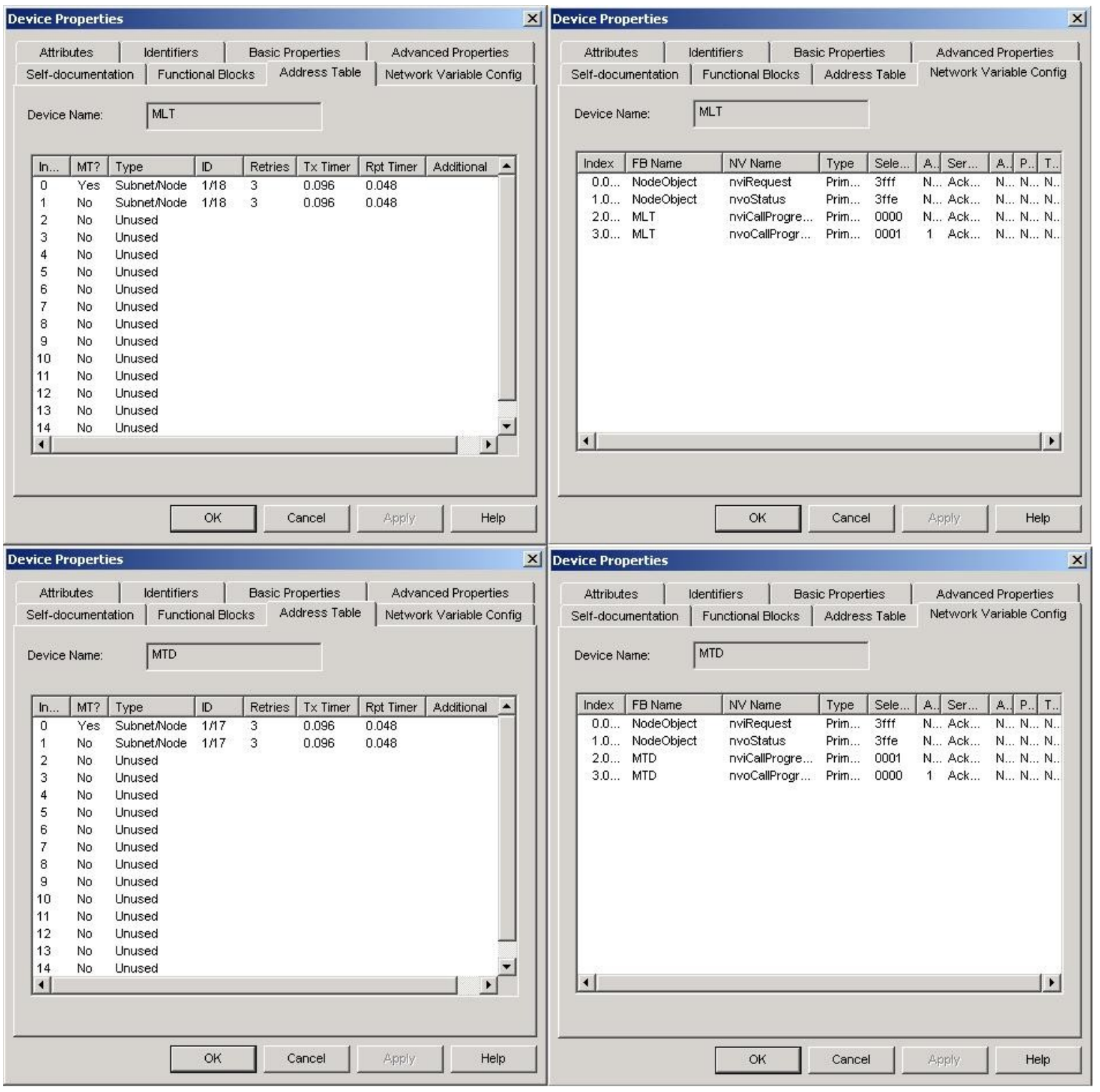

Figura 42 - Tabelas geradas pelo processo de bindings dinâmicos

Como se podem observar, as tabelas geradas são exatamente as mesmas, com exceção dos seletores utilizados, pois através do LonMaker não se sabe como eles são gerados, e no processo desenvolvido é utilizado uma contagem crescente inicializada em zero.

Portanto, a somatória dos resultados dessas duas primeiras etapas configuram o processo para a utilização de bindings dinâmicos entre dois nós da rede LonWorks $^{\circledR}$, permitindo que eles negociem e realizem as configurações necessárias para o relacionamento de suas variáveis.

No contexto do projeto do SDCTP, pode-se afirmar agora que o mesmo é viável tecnicamente, uma vez que constatou-se a viabilidade de se realizar 
dinamicamente os enlaces telefônicos, restando apenas agora comprovar que os mesmos podem ser dinamicamente desfeitos.

\subsubsection{Terceira Etapa}

Por fim, esta etapa envolve o processo de desfazer as configurações realizadas, para deixar o dispositivo pronto para a realização de um novo enlace telefônico.

Esse processo deverá ocorrer após o envio de uma mensagem que indique a finalização da chamada. Em uma chamada telefonica comum, essa sinalização ocorre quando o usuário que originou a chamada coloca o monofone no gancho.

No SDCTP o fim de uma ligação é indicado pelo envio de uma mensagem do MLT para o MTD ou vice-versa, indicando que algum dos usuário colocou o monofone no gancho, através da variável de rede nvoCallProgress.

A Figura 43 apresenta uma cópia da tela do analisador de redes para esse processo, indicando a seqüência de eventos descrita.

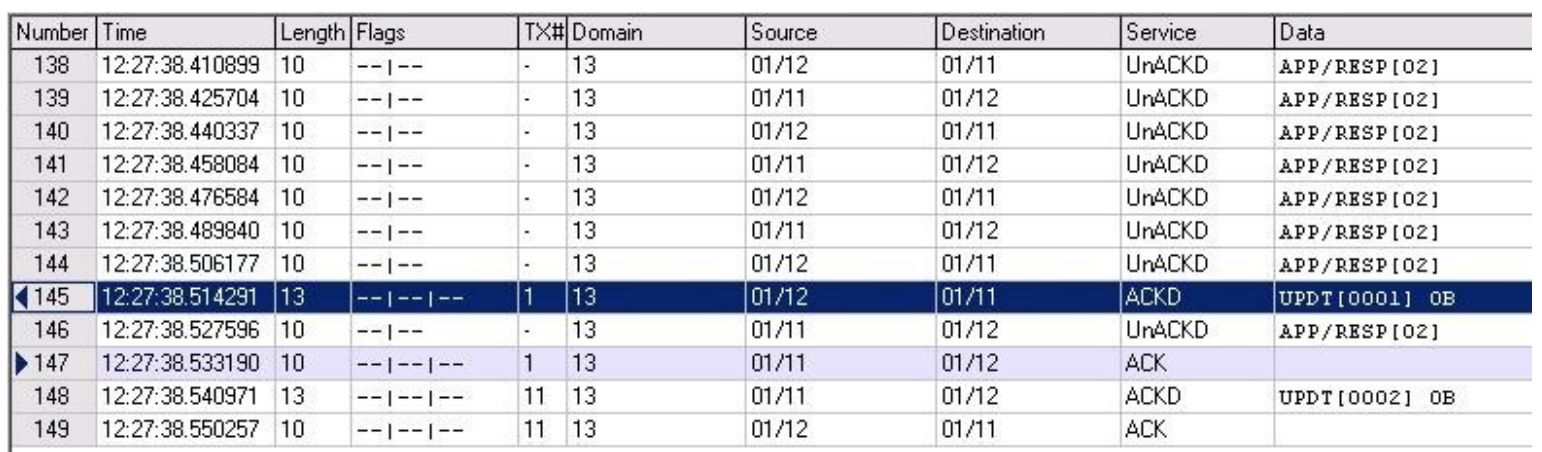

Figura 43 - Finalização do enlace telefônico

As mensagens com o número de 138 a 144 são mensagens de voz, indicando que os usuários estavam conversando e que o enlace telefônico estava fechado. Elas são transmitidas através de mensagens, não variáveis de redes, configuradas nas etapas um e dois.

A mensagem de número 145, marcada de azul, indica que o MTD enviou ao MLT a informação que o seu usuário colocou o monofone no gancho (através do dado 0x0B). Como neste exemplo a chamada é originada de um usuário externo, a transmissão de voz foi apenas cessada sendo o enlace mantido ativo.

Apenas quando o MLT envia a informação de monofone no gancho, 
mensagem de número 148, também com o dado 0x0B é que ambos os dispositivos desfazem os bindings.

A Figura 44 apresenta uma cópia da tela com as tabelas dos dispositivos após o processo de desfazer os bindings.

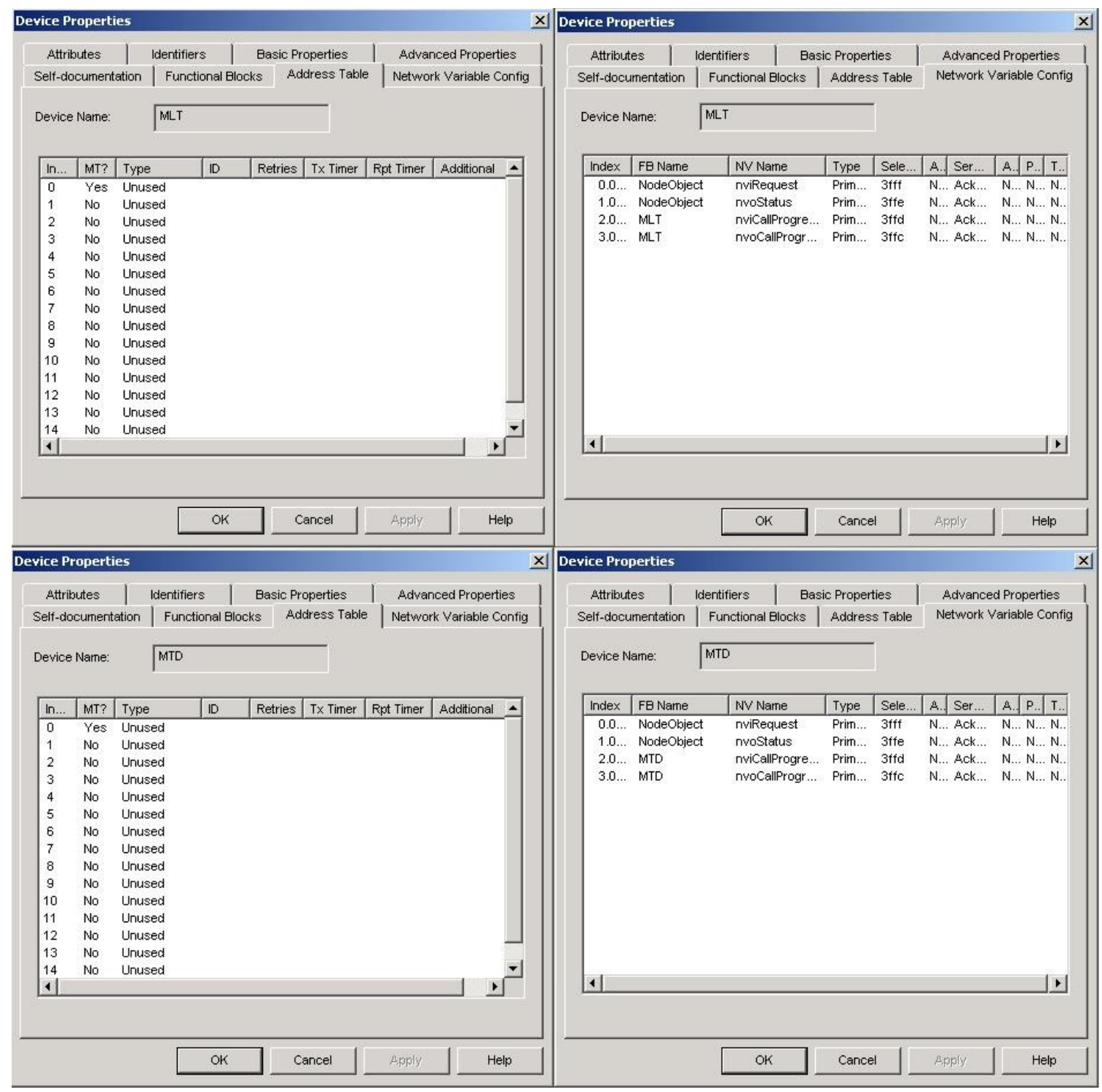

Figura 44 - Tabelas após desfazer as configurações de bindings

Com se pode observar, as tabelas de endereços dos dispositivos estão totalmente vazias, uma vez que as entradas utilizadas pela nvoCallProgress e pela mensagem Voz não estavam sendo compartilhadas por nenhuma outra variável e foram apagadas.

Da mesma forma, nas tabelas de configurações de variáveis de rede, os seletores foram programados para indicar que as variáveis não possuem 
bindings, ou seja, foram configurados com o número 0x3FFF subtraído do índice da variável (conforme especificado pelo protocolo LonTalk), e no campo responsável por indicar qual entrada da tabela de endereços a variável está utilizando foi gravado um valor indicando nenhuma, neste caso, o valor 15.

Com isso, pode-se observar que os dispositivos foram corretamente configurados e agora estão totalmente disponíveis para a realização de novos bindings, ou seja, o recebimento de novas ligações.

\subsection{CONCLUSÃO}

Avaliando de forma funcional, a solução apresentada se mostrou satisfatória, uma vez que os bindings foram realizados com sucesso e conforme os padrões e especificações da tecnologia LonWorks ${ }^{\circledR}$.

Ao fim das etapas um e dois, os bindings estavam corretamente configurados e os dispositivos estavam trocando mensagem exatamente da mesma forma que o fariam se tivessem sido configurados por uma ferramenta de rede padrão.

Já ao fim da etapa três, os dispositivos estavam configurados como se nenhum binding tivesse sido feito e de forma a poderem realizar a conexão novamente, ou através de uma ferramenta de gerenciamento ou da repetição das etapas um e dois.

Observa-se nas três etapas, que todos os conceitos relacionados à sistemas multiagentes apresentados, foram aplicados de forma intrínseca à solução proposta, mais especificamente, cada um dos dispositivos envolvidos (o MLT e o MTD) foram modelados como agentes reativos.

Cada um dos dispositivos possui um objetivo próprio que contribui para que o objetivo geral do sistema seja atingido, sendo esse objetivo geral é a formação de enlaces telefônicos para permitir que os usuários conversem através do telefone.

O MLT possui, primeiramente, o objetivo de se comunicar com o MTD atendente para obter os dados necessários para a sua configuração; depois seu objetivo passa a ser o de alterar suas configurações internas para interagir com o MTD; e por fim, seu objetivo é desfazer a configuração de forma a ficar livre para 
uma nova chamada.

De forma análoga, o MTD primeiramente possui o objetivo de, após receber um estímulo da rede, procurar seletores livres para a conexão; depois seu objetivo passa a ser o de realizar os bindings; e por fim, seu objetivo é se configurar para retornar ao estado inicial para receber novas ligações.

Como se pode observar, ambos os dispositivos possuem objetivos bastante simples e complementares e nenhum deles possui o conhecimento do objetivo global. Além disso, eles não são capazes de escolher qual objetivo irá realizar, eles são programados de forma indireta como uma seqüência de ações a estímulos que recebem do mundo externo.

Também devido à limitação da capacidade de processamento e memória, esses dispositivos não possuem qualquer modelo do ambiente em que estão inseridos, deles próprios ou de outros agentes no sistema; e também não são capazes de fazer inferências, buscar conhecimentos ou escolher uma determinada ação.

Por fim, cabe destacar que cada dispositivo foi totalmente autônomo nos processos internos de configuração que deve realizar, ou seja, após decidir os seletores a serem utilizados, cada um configurou a si próprio. Essa é uma característica importante para classificar o dispositivo como um agente do sistema e não é encontrada nos atuais dispositivos de rede LonWorks ${ }^{\circledR}$ quando se trata do gerenciamento de dispositivos na rede.

A única ressalva diz respeito à forma de comunicação entre os dispositivos. Neste caso, apesar da comunicação realizada ser bastante simples, envolvendo apenas a troca de poucas mensagens, é utilizado um protocolo de comunicação, o que desqualifica os dispositivos como agentes puramente reativos.

Um fato importante é que as conexões realizadas por outras ferramentas não foram alteradas, pois como os processos desenvolvidos envolvem a varredura e verificação das configurações já existentes nas tabelas, caso um binding já tivesse sido configurado anteriormente ele não será alterado.

Isso é importante para garantir que configurações estáticas possam coexistir em sistemas que utilizem os bindings dinâmicos, permitindo a interoperabilidade entre esse dois tipos diferentes de nós de rede. 
Caso o SDCTP não seja utilizado com outros equipamentos de controle, não é necessário garantir a sua interoperabilidade com outros equipamentos que seguem o padrão LonWorks ${ }^{\circledR}$, e o processo de determinação do seletor não será necessário, e uma vez que não existem outras ferramentas de gerenciamento determinando seletores para outras ligações, poder-se-ia utilizar valores pré-configurados.

Por exemplo, um enlace telefônico, poderia utilizar sempre os seletores zero e um; e a requisição de gravações de voz poderia utilizar os seletores dois e três e assim por diante. Isso tornaria o processo de formação dos enlaces ainda mais rápidos e simples de serem realizados, eliminando a etapa um.

Um requisito importante a ser atendido diz respeito ao tempo total de fechamento do enlace telefônico, que foi especificado para consumir um segundo. $O$ tempo médio total obtido, foi de aproximadamente $625 \mathrm{~ms}$, ou seja, quase a metade do tempo exigido.

Somente foi possível cumprir esse requisito, devido à visão de agentes utilizada para o desenvolvimento do sistema, que acrescentou a característica de que todo o processo interno é realizado pelo próprio agente em si, como uma unidade autônoma.

Caso se utilizasse um dispositivo externo para a realização de todas as configurações de bindings, os tempos obtidos seriam muito semelhantes ao obtido pelo LonMaker, ou seja, aproximadamente dois segundos, o dobro do tempo exigido.

Um possível problema levantado ao se realizar qualquer processo de binding dinâmico diz respeito ao tempo de vida útil dos dispositivos, uma vez que essas configurações são realizadas em EEPROM e sua vida útil depende do número de escritas a que ela é submetida.

O modelo de EEPROM utilizada internamente pelo NeuronChip tem uma capacidade de escrita de 1.000.000 (um milhão) de vezes (MOTOROLA, 1997). No caso de um callcenter, para citar um exemplo que envolve uma alta utilização de um sistema telefônico, são realizadas cerca de trinta ligações por dia (CLIENTE SA, 2009), como cada enlace exige duas gravações na memória, uma para fazer os bindings e outra para desfazer, serão realizadas sessenta escritas por dia na 
memória do Neuron.

Assim, os equipamentos do SDCTP poderiam ser utilizados no máximo por cerca de 16.666 dias, o que eqüivale a aproximadamente setenta anos. Ainda sim, caso se julgue necessário, esse tempo pode ser ampliado reduzindo-se a quantidade de escritas.

Uma forma de fazer isso seria estudar se realmente é necessário desfazer os bindings após o término da ligação. Ele poderia ser apenas substituído, se necessário, quando fosse feito um novo enlace, reduzindo pela metade a quantidade de escritas realizadas, e por conseqüência, duplicando o tempo de vida útil.

Portanto, pode-se considerar que o processo desenvolvido é eficiente e torna possível a realização de bindings dinâmicos para aplicação do SDCTP, respondendo a todos os requisitos exigidos pelo mesmo. 


\section{CONCLUSÃO}

\subsection{OBJETIVO DO TRABALHO}

O objetivo principal do presente trabalho, que foi desenvolver uma metodologia para a criação de dispositivos capazes de se autogerenciar, foi atingido com sucesso. Considerando o problema proposto para ser resolvido, envolvendo o SDCTP, pode-se afirmar que com a solução desenvolvida os seus dispositivos podem decidir os parâmetros necessários para efetuar a suas próprias configurações para a realização dos enlaces telefônicos de forma dinâmica.

Além da capacidade de se autogerir que os dispositivos da rede passam a possuir, uma premissa imposta no início do trabalho foi que essa metodologia para criação de dispositivos deveria utilizar técnicas baseadas em sistemas multiagentes, pelas razões discutidas anteriormente. Essa premissa se originou da semelhança entre o sistema SDCTP e o cenário tomado como estudo de caso com uma sociedade de agentes cognitivos ou reativos.

Como a tecnologia LonWorks permite a abstração de seus equipamentos como objetos distribuídos, apenas acrescentou-se uma camada de software para torná-los autônomos e dirigir as suas atitudes à objetivos globais. Assim, o uso de técnicas relacionadas com sistemas multiagentes apresentou bons resultados, estimulando o seu uso em outras aplicações correlatas.

\subsection{PRINCIPAL CONTRIBUIÇÃO DO TRABALHO}

A visão adotada de sistemas multi-agentes, em específico a adoção de uma visão de que cada dispositivo é considerado um agente do sistema, contribui para a eficiência da solução apresentada.

Um ponto a se ressaltar é que se procurou programar cada um dos módulos como um agente reativo, pois apesar de haver uma forma complexa de comunicação, não existe qualquer distinção ou conhecimento inserido nos agentes, que faça com que eles saibam o que são e com quem se relacionam. Eles apenas reagem a estímulos originados na rede de controle LonWorks, tomando atitudes coerentes e pré-programadas, e não são capazes de adotar um novo objetivo, de gerar uma base de conhecimento ou de intenções, características essas de agentes cognitivos. 
Essa visão conferiu originalidade à metodologia não se encontrando relatos na literatura de semelhante utilização em redes de automação baseadas na tecnologia LonWorks ou em aparelhos de PABX. Além disso, devido à simplicidade do agente desenvolvido, a aplicação não foi prejudicada, seja em termos de velocidade de processamento da aplicação, seja em termos de quantidade de memória requerida para suportá-la. Assim não houve prejuízos à operação básica prevista para o SDCTP.

Cabe ressaltar algumas vantagens identificadas no uso da metodologia proposta em relação às metodologias comumente utilizadas no projeto de sistemas de automação baseados em reles de controle:

- a velocidade obtida na configuração dos dispositivos

Como apresentado no capítulo anterior, o tempo total de configuração do dispositivo através da metodologia proposta é cerca de quatro vezes mais rápido do que através do processo utilizado nos métodos comumente utilizados.

- a confiabilidade do processo de configuração

Como cada dispositivo é capaz de realizar todo o processo de forma autônoma, a possibilidade de um dispositivo ser inutilizado devido a um processo mal terminado é bastante reduzido.

Como normalmente essas configurações são realizadas com ferramentas executadas a partir de um nó específico na rede, responsável por todo o processo, caso este seja interrompido subitamente, o dispositivo se torna inoperante, podendo permanecer em estados em que a aplicação não é executada ou executada com configurações inválidas de rede.

Nessa solução, caso o processo seja interrompido, o próprio dispositivo é capaz de restabelecer a si próprio, retornando a um estado em que a aplicação continue funcionando com configurações de rede válidas.

- a não interrupção da execução da aplicação

Essa é uma vantagem importante, principalmente em sistemas em que a aplicação não pode ser interrompida. Quando as configurações de rede são 
realizadas através de ferramentas ou dispositivos externos, é necessário que o dispositivo em processo de configuração seja passado para estados em que a aplicação é impedida de ser executada, permanecendo por cerca de dois segundos neste estado.

Através do procedimento desenvolvido, a aplicação não pára de operar e a comunicação de rede também permanece em funcionamento. Dessa forma, aplicações críticas podem utilizar essa metodologia e continuar a operar concomitantemente ao processo de reconfiguração.

No contexto do projeto SDCTP, esse trabalho contribui para a continuidade do seu desenvolvimento viabilizando-o tecnicamente. A partir de agora é possível a realização de enlaces telefônicos permitindo que todos os tipos de chamadas possam ser realizadas, assim como outros tipos de enlaces, como a utilização do MRA para atendimento automático, secretária eletrônica e chamadas entre ramais.

\subsection{OUTRAS CONTRIBUIÇÕES}

Durante a realização das pesquisas associadas ao presente trabalho identificou-se que melhorias na implementação do hardware dos nós podem favorecer a implementação da metodologia proposta. Como sugestão de mudança tem-se o desenvolvimento de um dispositivo que permita a classificação dos bindigns automáticos como bindings dinâmicos e deixem de ser armazenados na memória EEPROM e atrelados à uma verificação de CRC, e passem a ser armazenados em memória RAM. Com isso a limitação imposta pelo número máximo de apagamentos de memória EEPROM deixa de existir.

Cria-se assim um novo conceito de binding na tecnologia LonWorks $^{\circledR}$, uma vez que até então tem-se uma visão estática sobre esse processo, de forma que ele somente seja alterado mediante o uso de ferramentas de gerenciamento. Com uma metodologia eficiente de configuração de bindings entre os dispositivos, ele deixa de ser estático e passa a ser dinâmico na rede de controle, tornando-se mais semelhante às sinapses cerebrais, que podem ser feitas e desfeitas conforme padrões encontrados e necessidades momentâneas detectadas.

A flexibilidade advinda do novo conceito de binding possibilita o 
desenvolvimento de novas categorias de sistemas e produtos, com convergência de tecnologias que passa a integrar em um novo produto às funções de vários produtos. No caso do projeto de pesquisa do SDCTP, pode-se pensar agora na ampliação de suas funcionalidades, tornando a comunicação telefônica interna e externa a uma empresa, como parte do sistema de automação predial, que vem naturalmente sendo incorporados em novos projetos.

\subsection{PERSPECTIVAS DE CONTINUIDADE}

No contexto do projeto SDCTP, pode-se imaginar a possibilidade de aplicação de agentes cognitivos para a resolução de problemas de maior complexidade e que possam exigir um sistema com maior integridade e capacidade de decisão.

Como exemplo de problema de maior complexidade tem-se a decisão de qual ramal atendente irá atender a uma chamada recebida no caso de uma instalação onde existam muitos ramais atendentes. Deve-se decidir dentre aqueles que estiverem livres no momento da chamada, qual irá atendê-la; isso poderia ser feito através da utilização de leilões com métricas pré-estabelecidas, método muito utilizados em sociedades de agentes cognitivos (Benisch et al., 2004).

Tendo em vista um caso mais amplo, que envolve toda a tecnologia LonWorks $^{\circledR}$, pode-se propor a implementação e avaliação de um novo hardware para os nós da rede, que possibilitem o armazenamento das informações de bindings em memória RAM. Isso eliminaria a restrição associada à memória EEPROM já comentada no item anterior, permitindo o desenvolvimento de sistemas mais dinâmicos, com os bindings sendo feitos e desfeitos com maior freqüência. Essa alternativa possibilitará a realização do processo com maior rapidez, uma vez que o acesso de escrita em memória RAM é mais rápido do que em memória EEPROM, além de dispensar o recálculo de checksum.

Ainda no âmbito da tecnologia LonWorks ${ }^{\circledR}$, poder-se-ia investigar como reconfigurar redes ad-hoc, permitindo que a cada inclusão de um novo dispositivo em uma rede já existente e os serviços correspondentes sejam automaticamente integrados à ela. Caso um dispositivo seja desconectado, a rede automaticamente se reconfigura para operar sem ele, dando abertura à uma 
implementação simplificada de ambientes de controle pervasivos.

Uma sugestão de continuidade natural relacionada com o SDCTP é a concepção de sistemas de automação predial baseado na tecnologia LonWorks ${ }^{\circledR}$ que incorporem as funções de um PABX. Essa proposta tem diversos aspectos que devem ser avaliados, podendo-se citar: aspectos econômicos (melhor aproveitamento da infraestrutura instalada, maior facilidade de instalação e manutenção, e redução na quantidade de equipamentos são alguns exemplos), operacionais (cada aparelho telefônico se transforma em um terminal de acesso ao sistema de automação predial, podendo, por exemplo, permitir ligar ou ajustar o sistema de ar condicionado, ou ativar o sistema de alarme) e de confiabilidade (não existe mais um equipamento centralizado responsável por todo o processamento).

\subsection{CONSIDERAÇÕES FINAIS}

$\mathrm{Na}$ ocasião da realização da presente pesquisa não se encontrou na literatura relatos de soluções semelhantes, não apenas atestando a sua originalidade, mas estimulando o seu estudo. Acredita-se que a divulgação dos resultados desse trabalho estimule a concepção de sistemas que façam uso da tecnologia de binding dinâmico e conseqüentemente o seu aprimoramento e evolução, possibilitando até mesmo o desenvolvimento de novas categorias de sistemas e produtos, fruto da convergência de tecnologias, dada pela integração de funções comumente intrínsecas a cada família de produtos, em um único e novo produto. 


\section{REFERÊNCIAS}

AGÊNCIA NACIONAL DE TELECOMUNICAÇÕES. Resolução ANATEL, Anexo à resolução número 390: Regulamento para certificação e homologação de Centrais Privadas de Comutação Telefônica - CPCT. 2004. 59 p.

ALVES FILHO, M. S. Aplicação de Redes de Controle Distribuído em Processo de Pesagem Automatizado e Informatizado. 2001. 254 p. Dissertação (Mestrado) - Escola Politécnica, Universidade de São Paulo, São Paulo, 2001.

BENISCH, M., GREENWALD, A., GRYPARI, I., LEDERMAN, R., NARODITSKIY, V., TSCHANTZ, M., BOTTICELLI. A Supply Chain Management Agent. Proc. $3^{\text {rd }}$. Int. Conf. On Autonomous Agents and Multi Agent Systems (AAMAS'04), ACM Press (New York), p. 1174-1181, 2004.

BIGHAM, J., DU, L. Cooperative Negotiation in a Multi-Agent System for Real-Time Load Balancing of a Mobile Cellular Network. In: PROCEEDINGS OF THE SECOND INTERNATIONAL JOINT CONFERENCE ON AUTONOMOUS AGENTS AND MULTIAGENT SYSTEMS, 2., 2003, Melbourne (Australia). International Conference on Autonomous Agents. Nova York: ACM, 2003. p.568-575.

Melbourne, Australia, 2003.

BOISSIER, O., DEMAZEAU, Y. ASIC: An Architecture for Social and Individual Control and its Application to Computer Vision. Modelling Autonomous Agents in a Multi-Agent World, v. 1069, 1994.

CANOVAS, S. R. M. Integração entre redes LonWorks ${ }^{\circledR}$ e redes IP: aplicações, requisitos e soluções. 2006. 196 p. Dissertação (Mestrado) - Escola Politécnica, Universidade de São Paulo, São Paulo, 2006.

CANSADO, J. C. A. Agrilogic sistema para experimentação de controle de casas de vegetação. 2003. 118 p. Dissertação (Mestrado) - Escola Politécnica, Universidade de São Paulo. São Paulo, 2003.

CASTELFRANCHI, C. Modelling Social Action for Al Agents. Artificial Intelligence, Elsevier Science Publishers Ltd, v. 103, n. 1, p. 157-182, 1998.

CHERMONT, M. G. Proposta de Desenvolvimento de um Agente Proxy SNMP para Gerenciamento de Redes LonWorks. 2007. 84 p. Dissertação (Mestrado) Escola Politécnica, Universidade de São Paulo, São Paulo, 2007.

CLIENTE SA. São Paulo. Site de revista contendo informações a respeito do funcionamento dos sistemas de callcenters. Disponível em: $<$ http://www.clientesa.com.br/cases/?pag=matintegra\&mat|D=686>. Acesso em 18 jan. 2009.

COHEN, P. R., LEVESQUE, H. J. Intention Is Choice with Commitment. Artificial 
Intelligence, Elsevier Science Publishers B.V. (North-Holland), v. 42, p. 213-261, 1990.

CONCEITO TECNOLOGIA. Site da empresa Conceito contendo informa,ões a respeito da tecnologia LonWorks e alguns exemplos de aplicação. Disponível em: $<$ http://www.conceitotecnologia.com.br>. Acesso em: 12 fev. de 2008.

CUNHA, R. A., CUGNASCA, C. E., CHERMONT, M. G. Proposta de Utilização de Técnicas de Sistema Multiagentes para Controle de Estufas. In: V CONGRESSO BRASILEIRO DE AGROINFORMÁTICA, SBI-AGRO, 5., 2005, Londrina - PR. Anais do V Congresso Brasileiro de Agroinformática, SBI-AGRO.

DURFEE, E. H., ROSENCHEIN, J. S. Distributed Problem Solving and Multi-Agent Systems. Proceedings of the International Workshop on Distributed Artificial Inteligence, 1994.

ECHELON CORPORATION. Site da Empresa contendo informações sobre a empresa e a tecnologia LonWorks ${ }^{\circledR}$. Disponível em: <http://www.echelon.com>. Acesso em: 17 de junho de 2007.

ESTADOS UNIDOS. Echelon Corporation. Neuron C programmer's guide. Palo Alto, 1995. 1 v. (a).

ESTADOS UNIDOS. Echelon Corporation. Neuron C reference guide. Palo Alto, 1995. 1 v. (b).

ESTADOS UNIDOS. Echelon Corporation. Introduction to the LonWorks ${ }^{\circledR}$ System, Palo Alto, 1999. 1 v. (078-0183-01A).

ESTADOS UNIDOS. Echelon Corporation. LonWorks ${ }^{\circledR}$ FTT-10A Free Topology Transceiver User's Guide, Palo Alto, 2001. 1 v. (078-0156-01G).

ESTADOS UNIDOS. Echelon Corporation. LonMark Layer 1-6 Interoperability Guidelines, Palo Alto, 2002. 1 v.

ESTADOS UNIDOS. Echelon Corporation. LonMaker User's Guide, Palo Alto, 2003. 3.1 v. (078-0168-02E). (a)

ESTADOS UNIDOS. Echelon Corporation. NodeBuilder User's Guide. Palo Alto, Echelon, 2003. 1 v. (b)

ESTADOS UNIDOS. Motorola. LonWorks ${ }^{\circledR}$ Technology Device Data, rev. 4, 1997.

FIELDBUS FOUNDATION. Site da fundação contendo informações sobre o protocolo fieldbus. Disponível em : <http://www.fieldbus.org/> . Acesso em: $19 \mathrm{de}$ junho de 2007.

HANSMANN, U. et al. Pervasive Computing, 2nd edition, Springer Professional 
Computing, p. 448, 2003.

HÜBNER, J. F., SICHMAN, J. S., BOISSIER, O. A Model for the Structural, Functional, and Deontic Specification of Organizations in Multiagent Systems. In: PROCEEDINGS OF THE 16TH BRAZILIAN SYMPOSIUM ON ARTIFICIAL INTELLIGENCE (SBIA'02), 16., 2002, Porto de Galinhas (PE - Brazil), Lecture Notes In Computer Science. Londres: Springer-Verlag , 2002. p. 118-128.

HUR, S., KIM, D., PARK, G. Building automation system via LonWorks ${ }^{\circledR}$ and Linux based personal computer. Department of Electrical Engineering, Korea University, v. 1, n. 5 , p. $136-701,2005$.

INTELBRAS. Site da empresa Intelbras contendo informações a respeitos do seu produto PABX. Disponível em: <http://www.intelbras.com.br/pt/home/index.php>. Acessado em: 12 fev. 2008.

LIVIU, P., SEAN, L. A Pheromone-Based Utility Model for Collaborative Foraging. Proc. $3^{\text {rd }}$. Int. Conf. On Autonomous Agents and Multi Agent Systems (AAMAS), p. 36-43, 2004.

LONMARK INTERNATIONAL. Site do órgão padronizador das estruturas na tecnologia LonWorks e certificador de produtos. Disponível em: <http://www.lonmark.org/>. Acesso em: 19 jan. 2008.

LOYTEC. Site da empresa Loytec contendo informações a respeito de seu chip LCore. Disponível em: <http://www.loytec.com/english/products/lcore.htm>. Acesso em: 19 jan. 2009.

MODBUS-IDA. Site com informações sobre o protocolo modbus. Disponível em: $<$ http://www.modbus.org/>. Acesso em: 19 de junho de 2007.

PANASONIC. Site da empresa Panasonic contendo informações dos seus produtos PABX. Disponível em: <http://www.panasonic.com.br/categoria pai.asp? A1=148\&A2=148>. Acesso em: 12 fev. 2009.

PAZ, S. M. Proposta de um ambiente de apoio à pesquisa e ao desenvolvimento de equipamentos eletrônicos para Agricultura de Precisão. São Paulo, 2002. 147p. Tese (Doutorado) - Escola Politécnica da Universidade de São Paulo.

RAO, A. S. AgentSpeak(L): BDI Agents speak out in a logical computable language. Australian Artificial Intelligence Institute, 1996.

RAO, A. S., GEORGEFF, M. P. Modeling Rational Agents within a BDIArchitecture. Proceedings of the 2nd International Conference on Principles of Knowledge Representation and Reasoning (KR'91), Estados Unidos, p. 473-484, 1991.

ROSENSCHEIN, J. S., ZLOTKIN, G. Designing Conventions for Automated 
Negotiation. Readings in Agents, Morgan Kaufmann Publishers Inc. (San Francisco, CA, USA), p. 353-370, 1997.

SHOHAM, Y. Agent-Oriented Programming. Journal of Artificial Intelligence, n. 60, p. 51-92, 1991.

SIEMENS. Site da empresa Siemens onde pode ser encontrada informações a respeito de produtos PABX. Disponível em: <http://w1.siemens.com/entry/cc/en/>. Acesso em: 12 fev. 2008.

SOARES, J. O. P. Fundamentos conceituais para projeto de aplicações de computadores. São Paulo - SP, 1993. Tese (Doutorado) - Escola Politécnica da Universidade de São Paulo.

STEELS, L. Cooperation between distributed agents through self-organisation. Intelligent Robots and Systems '90. 'Towards a New Frontier of Applications', Proceedings. IROS '90. IEEE International Workshop, Japão, p. 8-14, 1990.

TANI, F. K. Proposta de Desenvolvimento de Transdutores Inteligentes Baseados no Norma IEEE 1451 Aplicados a Redes LonWorks ${ }^{\circledR}$. 2006. 178 p. Dissertação (Mestrado) - Escola Politécnica, Universidade de São Paulo, São Paulo, 2006.

TSE, W.L., CHAN, W.L., LAI, S.S. Emergency lighting monitoring system using LonWorks. Automation in Construction, v. 12, n. 5, p. 617 - 629, 2003.

WOODRIDGE, M., JENNINGS, N. Introduction to Multi-Agent Systems. Estados Unidos: JASSS, 2002.

XIE, C., PU, J.-S., MOORE, P. R. A case study on the development of intelligent actuator components for distributed control systems using LONWORK neuron chips. Mechatronics v. 8, n. 2, p. 103-119, 1998.

ZAMBONELLI, F., OMICINI, A. Challenges and Research Directions in AgentOriented Software Engineering. Autonomous Agents and Multi-Agent Systems. Kluwer Academic Publishers, v. 3, n. 9, p. 253 - 283, 2004. 